\title{
Geologic and Paleoecologic Studies of the Nebraska Sand Hills
}

GEOLOGICAL SURVEY PROFESSIONAL PAPER 1120-A,B,C

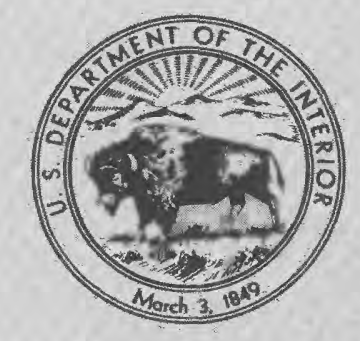





\section{Geologic and Paleoecologic Studies of the Nebraska Sand Hills}

Eolian Deposits in the Nebraska Sand Hills

By THOMAS S. AHLBRANDT and STEVEN G. FRYBERGER

Paleoecology of Nonmarine Mollusca from some

Paleointerdune Deposits in the Nebraska Sand Hills

By JOHN H. HANLEY

Late Quaternary Vegetation History of the Central Great Plains and its Relationship to Eolian Processes in the Nebraska Sand Hills By J. PLATT BRADBURY

GEOLOGICAL SURVEY PROFESSIONAL PAPER 1120 -A,B,C

From study of stratification and biota and interdune deposits, new information is obtained regarding the origin of the Nebraska Sand Hills

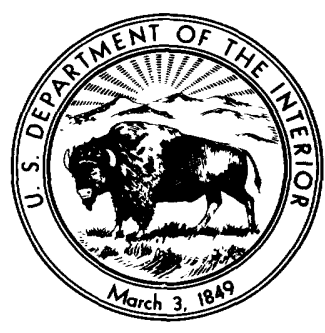




\section{UNITED STATES DEPARTMENT OF THE INTERIOR}

CECIL D. ANDRUS, Secretary

\section{GEOLOGICAL SURVEY}

H. William Menard, Director

Library of Congress Cataloging in Publication Data

Geologic and paleoecologic studies of the Nebraska Sand Hills.

(Geological Survey Professional Paper 1120)

Bibliography: p. 35

1. Geology-Nebraska-Sand Hills region. 2. Paleoecology-Nebraska-Sand Hills region.

3. Sand-dunes-Nebraska-Sand Hills region. I. Ahlbrandt, Thomas S. II. Title. III. Series: United States Geological Survey Professional Paper 1120.
QE136.S27U54
1979
$557.82^{\prime} 7$
$79-4127$

For sale by the Superintendent of Documents, U.S. Government Printing Office Washington, D.C. 20402

Stock Number 024-001-03290-2 


\section{CONTENTS}

[Letters designate the chapters. "Index" follows Chapter C on page 37]

Page

(A) Eolian deposits in the Nebraska Sand Hills, by Thomas S. Ahlbrandt and Steven G.

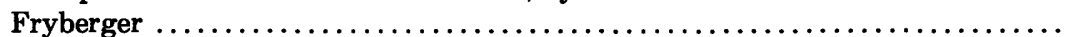

(B) Paleoecology of nonmarine Mollusca from some paleointerdune deposits in the Nebraska Sand Hills, by John H. Hanley .........................

(C) Late Quaternary vegetation history of the central Great Plains and its relationship to eolian processes in the Nebraska Sand Hills, by J. Platt Bradbury ............. 



\section{Eolian Deposits in the Nebraska Sand Hills}

By THOMAS S. AHLBRANDT and STEVEN G. FRYBERGER

GEOLOGIC AND PALEOECOLOGIC STUDIES OF THE NEBRASKA SAND HILLS

GEOLOGICAL SURVEY PROFESIONAL PAPER $1120-$ A 


\section{CONTENTS}

Page

Abstract

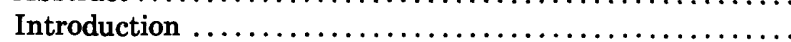

Distribution of the dune types . . . . . . . . . . . . . . . . . .

Thickness of the eolian sand $\ldots \ldots \ldots \ldots \ldots \ldots \ldots \ldots \ldots \ldots$

Past sand transport directions $\ldots \ldots \ldots \ldots \ldots \ldots \ldots \ldots \ldots$

Relationship of past sand transport to present wind ........

Orientation of laminae within dunes . . . . . . . . . . . . . . . .

Sedimentary structures in dunes.

Primary structures
1

1

3

5

5

7

7

8
Sedimentary structures in dunes-Continued

Secondary structures . ......................... 13

Dissipation structures $\ldots \ldots \ldots \ldots \ldots \ldots \ldots \ldots \ldots \ldots . \ldots \ldots$

Interdune deposits $\ldots \ldots \ldots \ldots \ldots \ldots \ldots \ldots \ldots \ldots \ldots \ldots, \quad 15$

Degradational processes in the Sand Hills ............ $\quad 19$

Sedimentary petrography ....................... 19

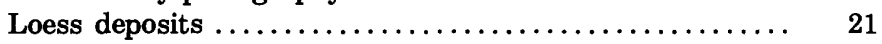

Acknowledgments ............................. 23

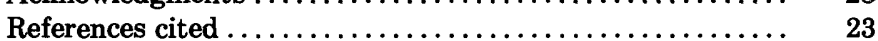

\section{ILLUSTRATIONS}

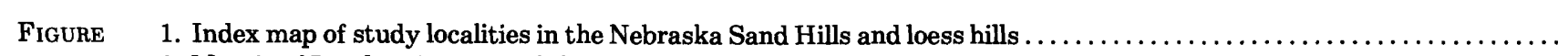

2. Mosaic of Landsat imagery of the snow-covered Nebraska Sand Hills during winter $\ldots \ldots \ldots \ldots \ldots \ldots \ldots \ldots \ldots$

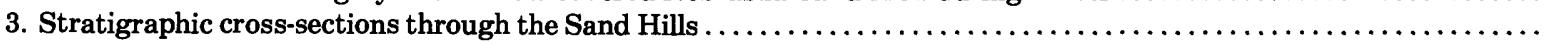

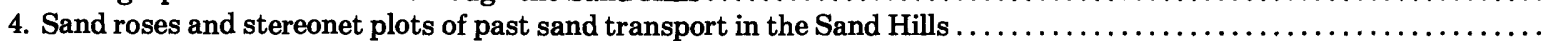

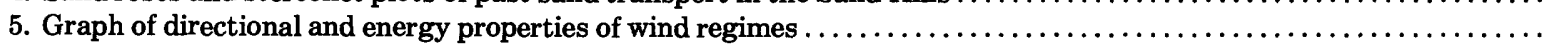

6. Stereonets and histograms of strike and dip data for barchan, transverse ridge, and blowout dunes $\ldots \ldots \ldots \ldots \ldots \ldots$

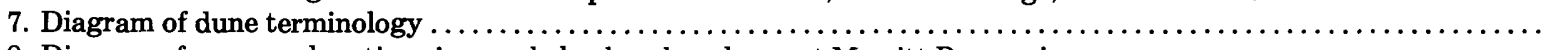

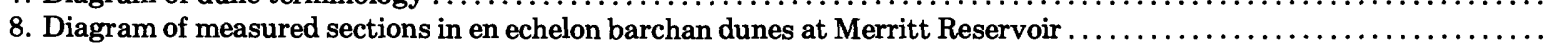
9-12. Photographs of:

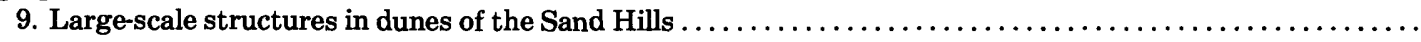

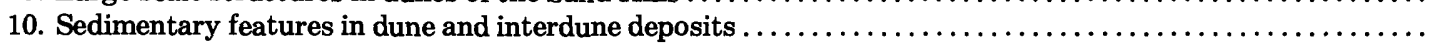

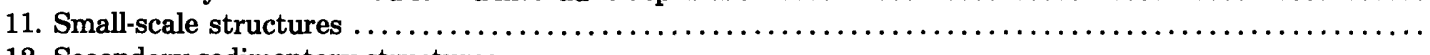

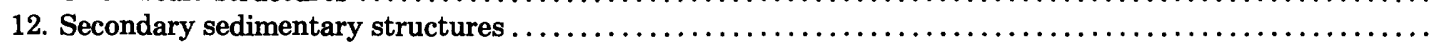

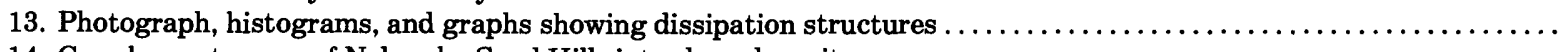

14. Gas chromatogram of Nebraska Sand Hills interdune deposit $\ldots \ldots \ldots, \ldots, \ldots, \ldots, \ldots, \ldots, \ldots \ldots \ldots \ldots \ldots$

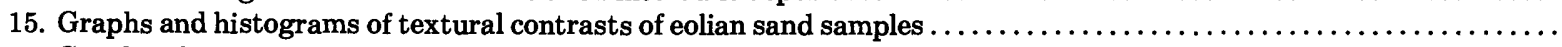

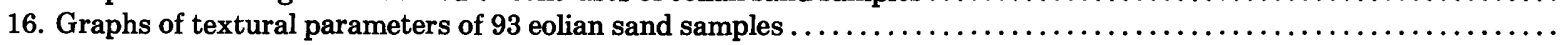

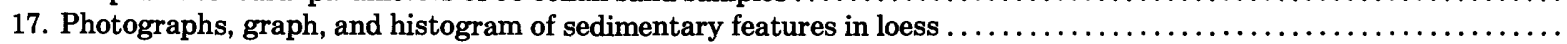

18. Well logs and lithologies of cross section showing loess deposits

\section{TABLE}




\title{
EOLIAN DEPOSITS IN THE NEBRASKA SAND HILLS
}

\author{
By Thomas S. AhlbrandT and Steven G. Fryberger
}

\begin{abstract}
The Nebraska Sand Hills are an inactive, late Quaternary, most probably Holocene, dune field (covering $57,000 \mathrm{~km}^{2}$ ) that have been eroded along streams and in blowouts, resulting in excellent lateral and vertical exposures of the stratification of dune and interdune sediments. This paper presents new data on the geometry, primary sedimentary structures, modification of sedimentary structures, direction of sand movement, and petrography of these eolian deposits.

Eolian deposits of the Sand Hills occur as relatively thin (9-24 m) "blanket" sands, composed of a complex of dune and discontinuous, diachronous interdune deposits unconformably overlying fluviolacustrine sediments. The internal stratification of large dunes in the Sand Hills (as high as $100 \mathrm{~m}$ ), is similar to the internal stratification of smaller dunes of the same type in the Sand Hills, differing only in scale. Studies of laminae orientation in the Sand Hills indicate that transverse, barchan, and blowout dunes can be differentiated in rocks of eolian origin using both the mean dip angle of laminae and the mean angular deviation of dip direction.
\end{abstract}

A variety of secondary structures modify or replace primary eolian stratification in the Sand Hills, the more common of which are dissipation structures and bioturbation. Dissipation structures in the Sand Hills may develop when infiltrating water deposits clay adjacent to less permeable layers in the sand, or along the upper margins of frozen layers that form in the sands during winter.

Cross-bed measurements from dunes of the Nebraska Sand Hills necessitate a new interpretation of the past sand transport directions. The data from these measurements indicate a general northwest-to-southeast drift of sand, with a more southerly drift in the southeast part of the Sand Hills. A large area of small dunes $(<100 \mathrm{~m}$ high) described by Smith (1965) as linear or seif in the central part of the Sand Hills was interpreted by him on the basis of morphology only. We interpret these as transverse-ridge dunes that were generally moving to the south. Further, our measurements indicate that dunes in the western part of the Sand Hills did not develop in response to present-day effective wind regimes. The presence of "transverse" and en echelon barchan dunes in the Sand Hills corresponds to a developmental sequence of barchan to linear dunes proposed by Tsoar (1978).

Dune and interdune deposits of the Sand Hills are subfeldsarenites to feldsarenites. Sand grains are commonly coated with montmorillonitic clay, which may be the local source of the clay concentrated in the dissipation structures. Textures of sand samples taken from adjacent layers within a dune were as dissimilar as textures of samples taken from widely separated dunes. This common occurrence indicates that textural data must be used carefully and in combination with other data to recognize ancient rocks of eolian origin.

Organic material derived from a variety of flora and fauna that inhabit the interdunes (chapters B and C) generated both oil and gas upon heating. Thus, interdune sediments may be an indigenous hydrocarbon source if buried in eolianites.

The twofold stratigraphy of loess and correlative dune deposits in the Sand Hills proposed by Reed and Dreeszen (1965) could not be confirmed by the present study. Rather, available data indicate that the dunes represent a single formation as suggested by Lugn (1935).

\section{INTRODUCTION}

The Nebraska Sand Hills are the largest dune field in the Western Hemisphere, occupying $57,000 \mathrm{~km}^{2}$ in central Nebraska (fig. 1). The dune field is now stabilized by vegetation, and erosion of the Sand Hills has produced many large outcrops that permit the detailed examination of the stratification of eolian deposits in this inland sand sea. In this paper, we present new data on the geometry, direction of sand transport, sedimentary structures, and modification of structures and petrography of these dunes and interdune deposits. These data should be useful to geologists in interpreting eolianites.

The Sand Hills are bordered by through-flowing streams-the Niobrara River to the north and the North Platte and Platte Rivers to the south. Some perennial streams originate within the dune field (for example, the Snake River, Middle and North Loup Rivers, and Dismal River) (fig. 1). Precipitation in the Sand Hills ranges from $406 \mathrm{~mm} / \mathrm{yr}$ on the western margin of the dune field to $610 \mathrm{~mm} / \mathrm{yr}$ on the eastern margin of the dune field. The dunes occur at an elevation of from 670.5 to $1,310.6 \mathrm{~m}$ in a semiarid, cool climate with a mean annual temperature of $8.9^{\circ} \mathrm{C}$ and a range of $-40^{\circ} \mathrm{C}$ to $43.3^{\circ} \mathrm{C}$ (Keech and Bentall, 1971).

The Sand Hills seem to have developed in the late Pleistocene, probably during the late Wisconsin or Holocene. $\mathrm{A}{ }^{14} \mathrm{C}$ date of 12,600 years B.P. (before the present), obtained for basal sediments in a core hole, is 


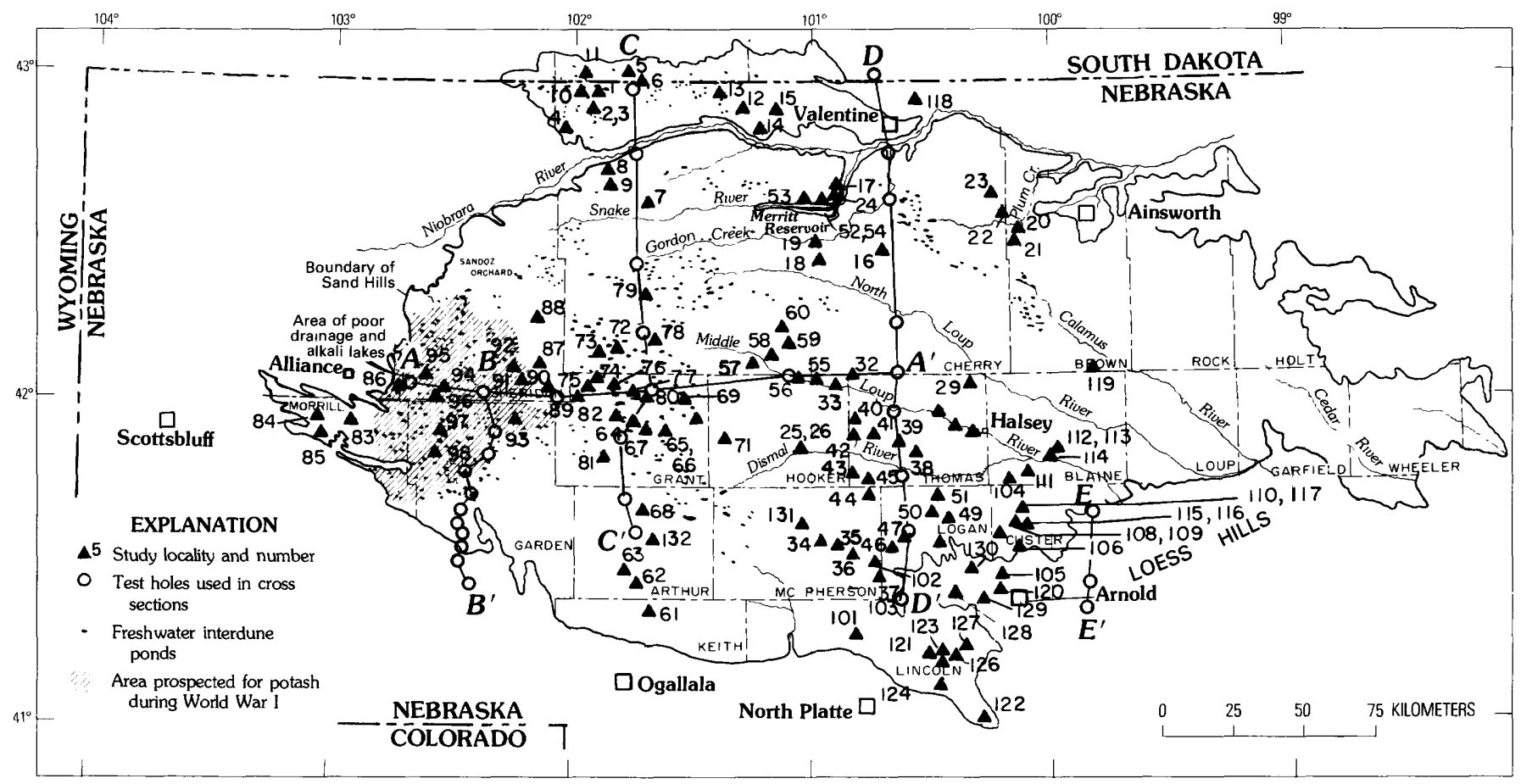

Figure 1.-Study localities in the Nebraska Sand Hills and loess hills. Base modified from Keech and Bentall (1971).

the oldest age of dated material of which we are aware in the Sand Hills (Watts and Wright, 1966). Valley fill beneath dune sand along the southeastern margin of the Sand Hills in Blaine County was dated by ${ }^{14} \mathrm{C}$ at $8,400 \pm 250$ yrs. B.P. by Brice (1964). During our field work, two nondiagnostic fragments of bison bones were collected in place at two dune localities (loc. 32 and 89). The bones from both localities were identified as ?Bison (Bison) bison (Linnaeus) of probable Holocene age by G. E. Lewis (written commun., 1975) of the U.S. Geological Survey. Faunal and floral analyses of samples from three interdune ponds at higher elevations than those of the present interdune surface provide data on the more recent history of the Sand Hills (chapters B and C) and indicate a Holocene age for the Sand Hills.

The upper Tertiary Ogallala Formation in original or reworked form has been suggested as the source of the dune sand by Lugn $(1935,1960,1962)$. Stanley and Wayne (1972) and Reed and Dreeszen (1965), among others, suggested a lower Pleistocene alluvial source. We conducted a mineralogic study of 7 dune and interdune sand samples, and textural analyses were made of 93 samples. Available mineralogic and textural data are too limited to ascertain the source sediments for the Sand Hills.

Several studies of dunes in the Sand Hills describe mainly dune morphology (Lugn, 1935; and Smith, $1965,1968)$ or morphology and texture of the dune sand (Warren, 1968). The interdune areas, in particular freshwater and alkaline ponds and lakes, have been studied both hydrologically and geologically. The works of Condra $(1918,1932)$ and Hicks (1921) summarize the economic importance of the alkaline lakes in the production of potash during World War I. Freshwater ponds have been analyzed for mollusks (chapter B), for pollen and seed profiles (Sears, 1961; Watts and Wright, 1966; chapter C), and for algae and water chemistry (Anderson and Walker, 1920; Bradley and Rainwater, 1956).

Lugn (1935) named the dune sand in the Sand Hills the Sand Hills Formation. Reed and Dreeszen (1965) divided the dune sand into the Peoria Dunesand and Bignell Dunesand, which they correlated with the medial Wisconsin Peoria Loess and the upper Wisconsin and Holocene Bignell Loess; the fluviatile equivalents were called the Peoria Formation and Bignell Formation respectively. The question of whether the loess is genetically related to the Sand Hills or to some other source (such as glacial or fluvial) is widely debated. The source of the loess and relative ages of the loess and dune sand are discussed by E. C. Reed and A. L. Lugn (in Schultz and Frye, 1968). Lugn (1968) and Wehrman (1961) indicated that loess and dune sand are interlayered within a transition zone between the Sand Hills and Loess Hills in central Nebraska (figs. 1, 2). We studied this transition zone in Custer and Logan Counties in an attempt to define the loess-dune sand relationship. 


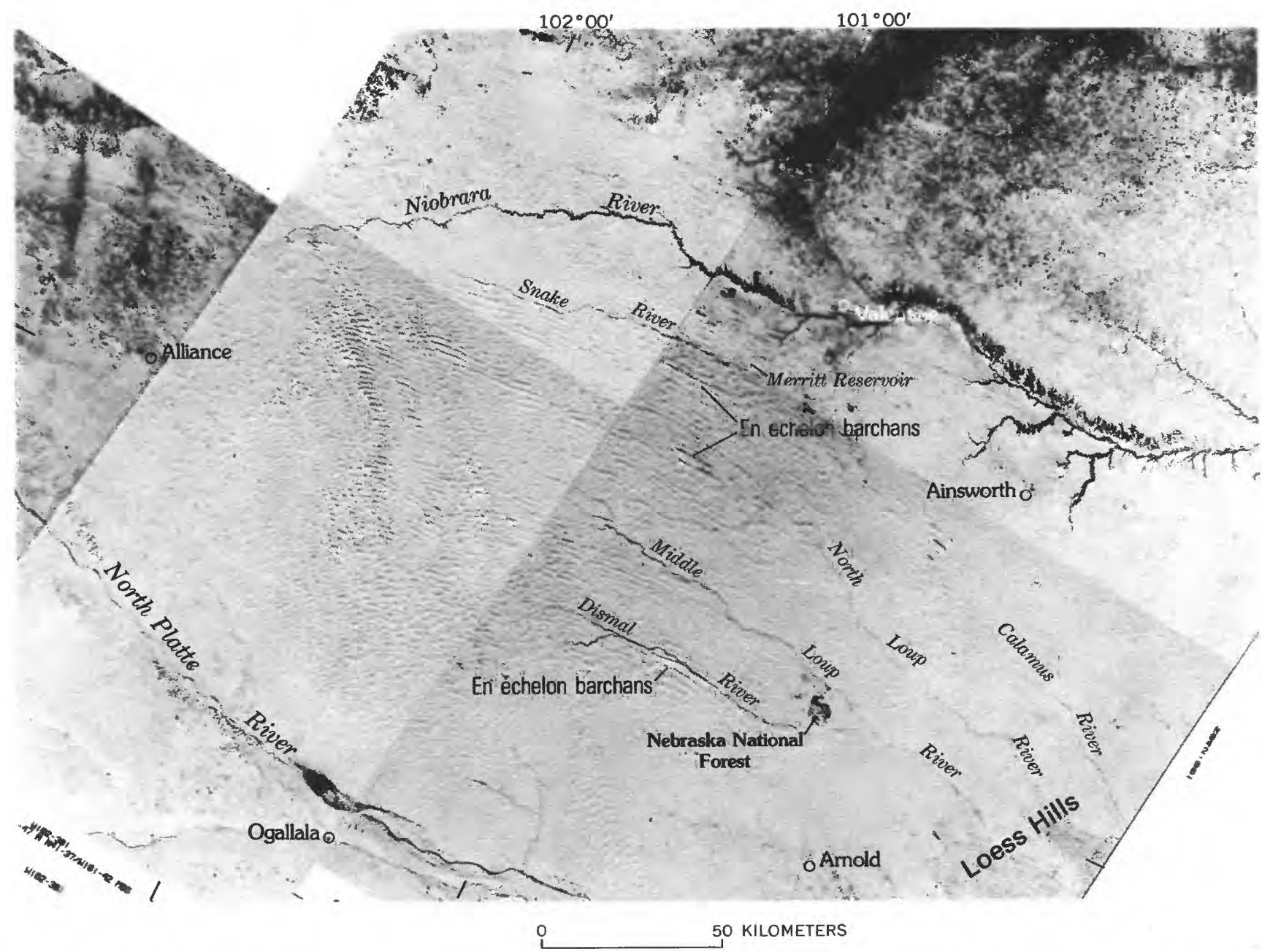

Figure 2.-Mosaic of Landsat imagery of the snow-covered Nebraska Sand Hills during winter. Both large dunes (Series I of Smith, 1965) and relatively smaller dunes (Series II of Smith, 1965) can be seen between the North Platte and Niobrara Rivers. Note the en echelon arrangement of barchan and barchanoid-ridge dunes, suggesting an early stage of evolution of barchan dunes to linear dunes.

\section{DISTRIBUTION OF THE DUNE TYPES}

The Sand Hills dunes can be classified as simple or compound (primarily transverse) types including dome (the small variety described by McKee, 1966; Ahlbrandt, 1975), barchan, barchanoid-ridge (McKee and Moiola, 1975), transverse-ridge, parabolic, and blowout. Some dunes in Custer County have two slipfaces dipping in opposite directions and may be reversing dunes, but internal stratification of these dunes were not well enough exposed for certain identification.

Barchan, barchanoid-ridge, and transverse-ridge dunes as high as $91 \mathrm{~m}$ are widespread throughout the Sand Hills region (fig. 3). A group of the largest of these dunes extends roughly from north-northwest to south-southeast across the western part of the dune field. Dune heights are greatest in the central part of the dune field, decreasing in size to the north and south (fig. 3, section $D-D^{\prime}$ ). The large dunes are compound in form; for example, small transverse-ridge dunes occur on large transverse-ridge dunes. Large barchans are common at the margins of the dune field, as well as in the interior (fig. 2). Some large dunes, straight or gently curving in plan view (fig. 2), superficially resemble linear or seif dunes; but their internal stratification indicates that they are barchanoid-ridge and transverseridge dunes. Some of these dunes are alined oblique to the regional direction of the sand transport. Many developed from en echelon barchans (fig. 2) and may represent an early stage of evolution of barchan dunes to sinuous-crested linear dunes, a hypothesis proposed by Tsoar (1978).

Many low mounds as much as $\mathbf{5} \mathrm{m}$ high, with gently dipping, curved, parallel internal stratification, occur throughout the Sand Hills atop larger dunes. They may represent remnants of windward-slope or crestal deposits of older dunes, blowout deposits, or small 

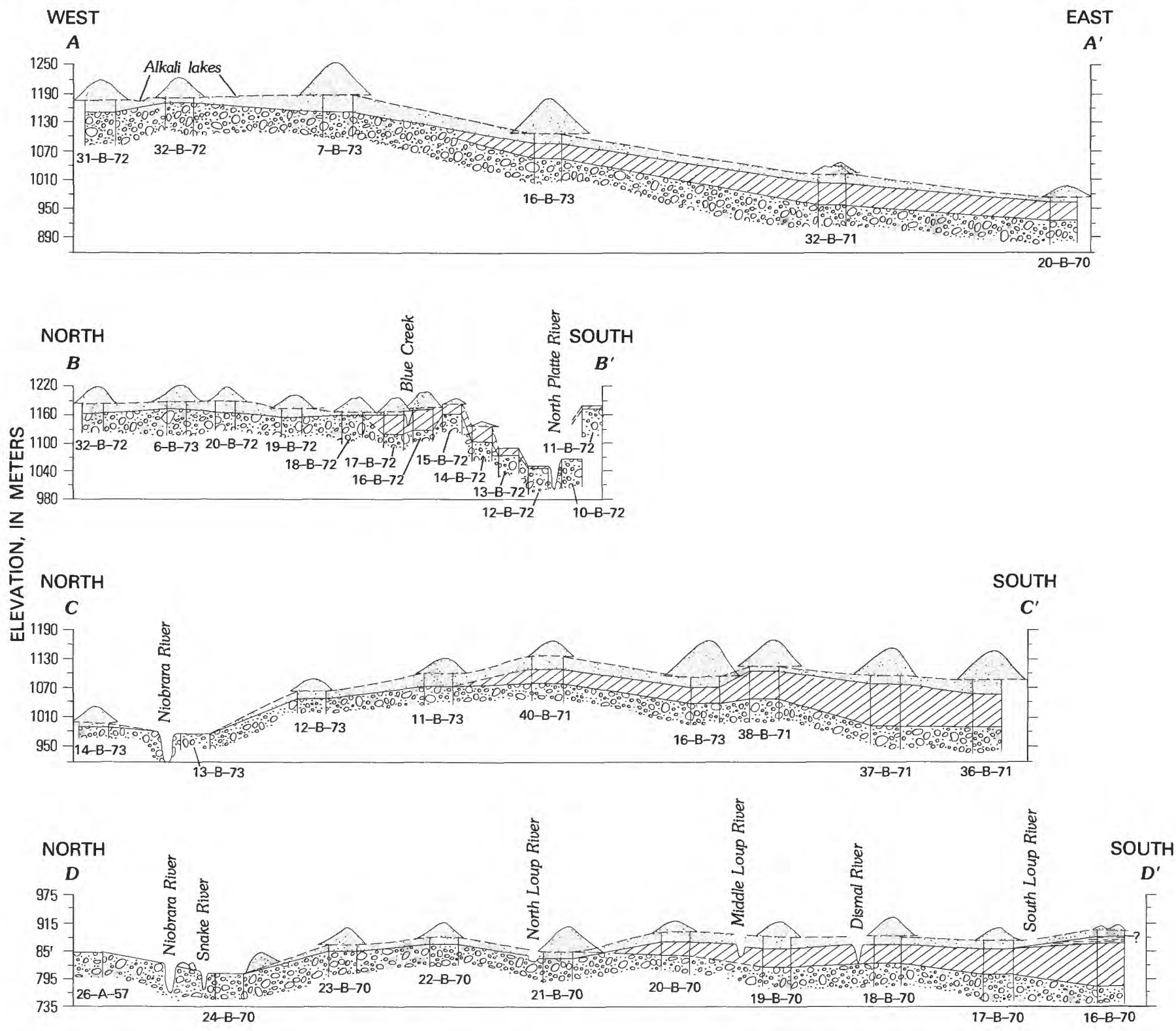

EXPLANATION
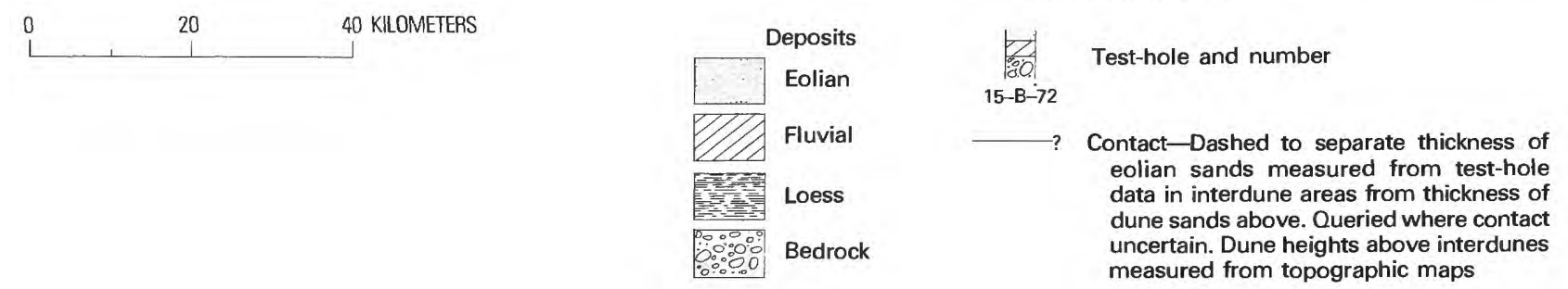

FIGURE 3.-Stratigraphic cross sections through the Nebraska Sand. Hills. The test-hole numbers used in the cross section are from data available at the Conservation and Survey Division, University of Nebraska, Lincoln. The height of dunes at each test-hole site is shown on each section. Vertical exaggeration X 86.

dome dunes, although dome dunes have not previously been described in compound association with other dune types.
The larger dunes visible in figure 2 are the Series I (large-scale transverse) dunes of Smith (1965). The Series II dunes (narrow longitudinal dunes of Smith, 
1965) were examined in trenches and road cuts throughout McPherson, Logan, Custer, Thomas, and Hooker Counties, where they are best developed. In all examples, the Series II dunes seem to be normal transverse-ridge dunes with nearly all cross-beds dipping steeply southward; thus they are not modified upsiloidal (parabolic) or longitudinal (seif) dunes as suggested by Smith (1965). The large dunes north of the Niobrara River (fig. 2), described by Smith (1968) as possibly analogous to large dome dunes (probably star dunes) in North Africa, are here interpreted as intensely reworked barchan dunes. The horns of several barchans can be distinguished in an illustration by Smith (1968, p. 40) and also in figure 2.

Blowout and parabolic dunes, the Series III of Smith (1965), are ubiquitous in the Sand Hills. They are secondary features that developed after the largest dunes were formed. Most blowouts are 3-5 m deep, although some are deeper. The maximum depth measured in a blowout was $12 \mathrm{~m}$. Blowouts and resulting deposits are oriented in many directions throughout the dune field, reflecting the present-day complex wind distributions over much of the Sand Hills.

\section{THICKNESS OF THE EOLIAN SAND}

The Sand Hills of Nebraska form a thin "blanket" deposit unconformably overlying either a southwardthickening wedge of unconsolidated Pleistocene fluvial deposits or consolidated sediments primarily of the Tertiary Ogallala Formation (fig. 3; Swinehart, 1972). In the southeastern portion of the dune field (Custer and Logan Counties), dune sand overlies loess in both outcrop and subsurface (fig. 3, Section $D-D^{\prime}$, test-hole 16-B-70). In general, the height of the dunes above the interdune surfaces is greater than the depth of eolian sand beneath the interdune surfaces.

The thickness of eolian sand below interdune surfaces generally ranges from 9 to $24 \mathrm{~m}$, with an observed maximum thickness of $37 \mathrm{~m}$ (fig. 3, 7-B-73), as determined by analyses of lithologic descriptions and of electric logs of 35 test holes along the four cross sections. Spontaneous potential and resistivity electrical logs from the test holes were calibrated with lithologic descriptions. The depth at which pebbles, silts, clays, or indurated rocks were found was used as a lower boundary of eolian sand. The inferred sand thicknesses were then checked by measuring sections of complete exposures of dune and underlying material along the major streams. Along the Middle and North Loup Rivers and Dismal River, dune sand rests on fluvial sand. These test holes and lithologic descriptions are part of a cooperative drilling program by the U.S. Geological Survey and the Conservation and Survey
Division of the University of Nebraska. Test-hole data is available at the Conservation and Survey Division, University of Nebraska, Lincoln.

Dunes and eolian sand deposits do not occur at many localities south of the present-day through-flowing Niobrara River and North Platte and Platte Rivers (fig. 3, 13-B-73, 24-B-70). Dunes north of the Niobrara River are more heavily reworked than are those to the south.

Interdune deposits that contain abundant organic material are widespread throughout the Sand Hills, but with the exception of silty layers in some test holes in the western part of the Sand Hills, they are not extensive in the subsurface. This indicates that the organic-rich interdune deposits, although diachronous (chapter C), represent culminating events in the history of the dune field, and that such deposits did not occur or were not preserved extensively during the development of the dune field. Fine-grained, evaporitic paleointerdune deposits, where preserved as in the western Sand Hills, are local permeability barriers (Bradley and Rainwater, 1956).

\section{PAST SAND TRANSPORT DIREGTIONS}

The direction of dune-building winds and the inferred sand transport directions in a dune field are indicated both by the external morphology of a dune-in particular, the directions of dip of the slipface in transverse forms - and by the direction of dip of internal cross-bedding. Internal dip direction is more reliable than slipface orientation, because internal structures constitute a record of dune deposits preserved through time and thus represent a more complete record than does the slipface. The slipface of a stabilized dune may represent the effects of the last dune-building storm or even later reworking.

Data for analysis of sand tranport directions in figure 4 are based on approximately 1,000 strike and dip measurements of cross-beds in deep exposures within the dunes, along streams, in road excavations, in gullies, and in a few deep blowouts. All measurements were made on bedding exposed in trenches cut at one-meter vertical intervals. Although measurements were made in dunes north of the Niobrara River and in the western part of the Sand Hills, these data are not considered reliable owing to the intensive reworking of dunes in those regions. Only data from cross-beds deep within dunes and overlain by soil at least $0.6 \mathrm{~m}$ thick were used in the analysis. These deposits were distinctly more indurated than those in recently active or surficially reworked dune sand. These data then were plotted on stereonets (fig. 4). 


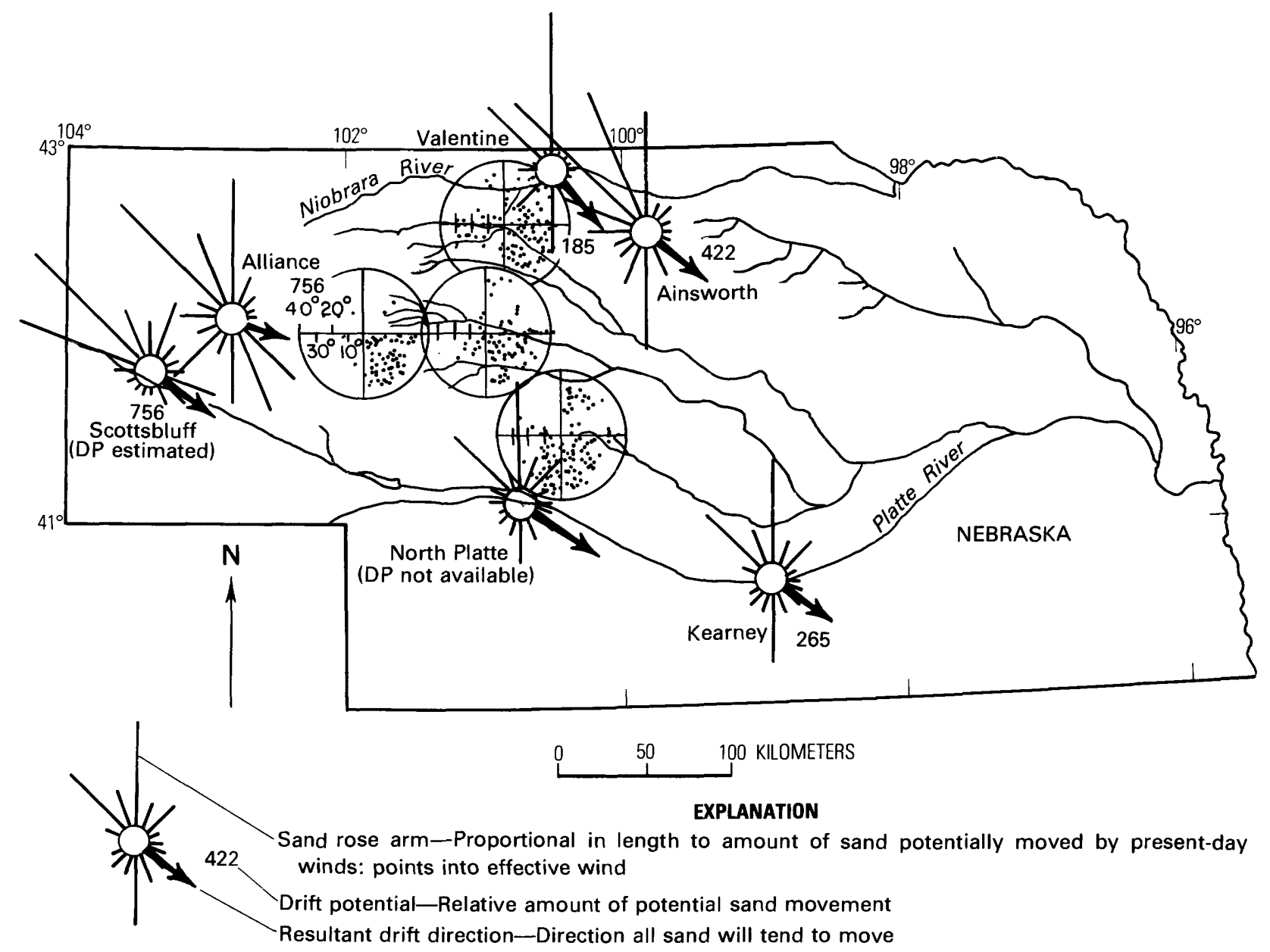

FIgURE 4.-Past sand transport in the Sand Hills shown on lower hemisphere stereonet plots of dip-and-strike data from internal dune cross-beds. Stereonets cover the portion of the map area from which data were collected. Present effective wind regimes are indicated by sand rose (Fryberger, 1979).

Analysis of the stereonet plots indicates a general northwest-to-southeast drift of sand, except in the vicinity of North Platte where the drift was southward. Our interpretation differs from previous interpretations of the past sand transport in the Sand Hills. Two principal directions of sand transport-to the southwest and directly to the east-were inferred by Smith (1965) from dune morphology. We now interpret the large area of small linear or seif dunes in the southeastern part of the Sand Hills, described by Smith (1965), to be transverse-ridge dunes that migrated predominantly to the south.

Despite the great length of many dunes with straight or gently curving plans, none were found to be linear (seif) dunes in the sense that they were constructed from major sets of opposite-dipping slipface deposits as described by McKee and Tibbitts (1964). At some locations, dip directions of cross-beds suggested slipface growth at an angle oblique to the trend of the dune as a whole (compare resultant drift direction, fig. 4, with dunes near Valentine, fig. 2). These data, as well as morphological evidence, show that some seemingly straight dunes have developed from en echelon barchans (fig. 2), as previously discussed, and perhaps represent an early stage of evolution of barchan dunes into linear dunes using Tsoar's (1978) concepts as to the origin and relative age of linear dunes.

The bimodal dip-directions in the North Platte and Arnold vicinity (fig. 2) reflect the occurrence of sets of small transverse ridge dunes facing in nearly opposite directions.

The trend of past sand transport direction in the Sand Hills is roughly similar in magnitude and curvature to similar trends south of latitude $30^{\circ}$ north in Algeria and at latitude $30^{\circ}$ north in Saudi Arabia (Fryberger, 1979). These trends parallel circulation patterns of typical midlatitude high pressure cells. 


\section{RELATIONSHIP OF PAST SAND TRANSPORT TO PRESENT WIND}

Present-day effective winds were evaluated using sand roses-circular histograms (fig. 4) in which the "arms" of each rose are proportional in length to the amount of sand that can be moved by the wind from a given direction toward the center of the rose (Fryberger, 1979). The arrow near each rose indicates the net direction of sand transport, or resultant drift direction. The terms used to describe relative amounts of sand potentially moved by winds at a station are drift potential, which is the total potential sandmoving power of all winds, and resultant drift potential, which is the magnitude of the net potential sand transport in a given direction when the effects of wind from various directions are considered as vectors. The principal advantage of using sand roses is that wind regimes can be described quantitatively and classified according to properties of direction and energy (fig. 5).

If present-day wind regimes are compared with dune types in the Sand Hills, a wide discrepancy is found for some stations (fig. 5). For example, the wind regime at Alliance, a short distance from transverse dunes along the western margin of the dune field, is more compatible with the star-dune type than with the transverse type (fig. 5). Similarly, the present-day wind regime at Ainsworth seems more compatible with linear dunes than with the transverse dunes in this area. Presentday wind regimes in the Sand Hills mostly have high drift potentials $(>400)$ and low resultant drift potentials. Were it not for the rainfall of the region, which

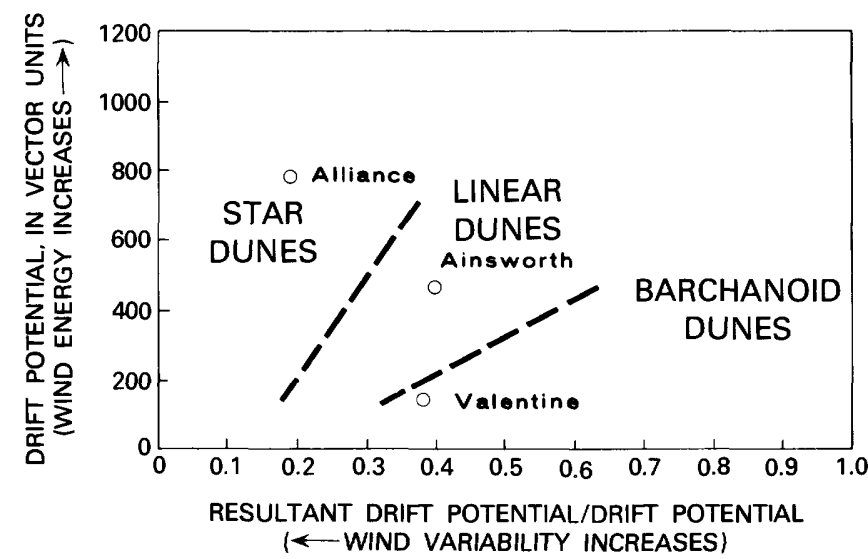

Figure 5.-Approximate directional versus energy properties of wind regimes associated with transverse, linear, and star dunes, based on data from Fryberger (1979). Low-energy wind regimes are 0-199 vector units (V.U.); intermediate energy, 200-399 V.U.; and high energy, 400 V.U. or greater. Present-day wind regimes in the Nebraska Sand Hills are indicated by dots. Present wind regimes are more characteristic of star or linear dunes than of the transverse type preserved in the Sand Hills. Dashed lines indicate approximate boundaries of dune type with wind regime. supports a stabilizing vegetation, the sand sea would be very active, and, in some areas, the dune forms would be different from those existing today.

The nature of the change in wind circulation from the time of the dune building to the present cannot be determined from available data. However, if the southerly to southeasterly component of the modern wind regimes were not present, wind regimes would be compatible with the regionally common transverse dune types. A shift from an older regime of westerly effective winds to a younger regime of southerly effective winds has been documented for southern Oklahoma, western Texas, and southeastern New Mexico by Melton (1940). The wind drift type dunes built by an older westerly wind regime were considered by Melton (1940) to have formed at least 15,000 years B.P. (although this figure is not based on a radiometric determination), so possibly the introduction of the southerly-southeasterly component of the wind regimes in the region Melton studied and in Nebraska may have been roughly contemporaneous but more recent than previously reported (chapter $\mathbf{C}$ ).

If the southerly component of present-day winds were removed, resultant drift directions would be more southerly (fig. 4). Present-day resultant drift directions compare favorably, although not perfectly, with transport directions indicated by internal stratification of the Sand Hills dunes. The present analysis of internal cross-stratification does not agree with the suggestion by Smith (1965) that a major shift in effective wind direction occurred during the building of the sand sea. Our interpretation is that resultant drift directions remained steady during the growth of the dunes, forming an arc from southeast through south. Anomalous trends of transport, such as that indicated by northeast-facing dunes in the Arnold area (loc. 110, fig. 1; see also stereonet for dunes near North Platte, fig. 4), may represent the results of a single storm (perhaps the later southerly effective winds) prior to dune stabilization. Although blowout deposits (Series III, Smith, 1965) clearly are younger than the Series I and II dunes, we found no evidence to indicate that larger dunes (Series I, Smith, 1965) represent a different period or cycle to activity than that of the smaller dunes (Series II of Smith, 1965).

\section{ORIENTATION OF LAMINAE WITHIN DUNES}

Detailed analysis of laminae dip direction and degree was undertaken in this study for barchan, transverseridge, and blowout deposits to see if any diagnostic strike and dip relationships would emerge. These data are similar to those typically available from cores and 
dip-meter logs. Strike and dip measurements from a number of sites in the same dune type were combined as shown in figure 6. Dune type in each area was diagnosed on the basis of both external morphology and internal structure as revealed in the best exposures. Topset deposits were not used in this analysis, because they conform to the topography of the dune and are rarely preserved within dunes. Failure to recognize upwind-dipping topset beds in shallow exposures may result in transverse dunes being incorrectly identified as linear dunes. The relation of topset and slipface deposits is schematically shown in figure 7.

Strike and dip were measured systematically along the entire length and height of a dune outcrop. To avoid apparent-dip problems, measurements were made in pits dug at 1-m vertical intervals and spaced at equal horizontal intervals to cover the entire exposure at $30.5-\mathrm{m}$ spacings.

The mean dip and mean angular deviation of dip, as computed by the statistical method described by Till (1974, p. 38-42), are as follows (see also fig. 6):

\begin{tabular}{cccc} 
Dune type & Mean dip $\left(^{\circ}\right)$ & $\begin{array}{c}\text { Mean angular } \\
\text { deviation }\left({ }^{\circ}\right)\end{array}$ & $\begin{array}{c}\text { Total dip } \\
\text { spread }\left({ }^{\circ}\right)\end{array}$ \\
\hline Transverse-ridge $\ldots \ldots \ldots \ldots \ldots$ & 24 & 32 & 90 \\
Barchan $\ldots \ldots \ldots \ldots \ldots \ldots \ldots$ & 22 & 54 & 180 \\
Blowout $\ldots \ldots \ldots \ldots \ldots \ldots \ldots$ & 16 & 54 & 180 \\
\hline
\end{tabular}

Transverse-ridge dunes have a narrower spread of dip directions than do barchan dunes. The wide spread of dips in barchan dunes reflects the curvature of the slipface of that type of dune. The narrow spread of dips in the transverse-ridge dune similarly is the result of a relatively straight slipface.

Although laminae within blowout dunes have the same mean angular deviation of dip directions as those in barchan dunes, the mean dip is much lower than that of laminae within either barchan or transverseridge dunes. The low mean dip value of laminae within blowout dunes reflects the general lack of slipface development on blowout dunes. The $180^{\circ}$ total spread of dip directions of laminae in blowout dunes is considerably less than the $270^{\circ}$ total spread of dip directions observed in parabolic dunes by McKee (1966) and by Bigarella (1975), although the growth of both blowout and parabolic dunes in the Sand Hills is controlled by vegetation. The narrower spread of dip directions in blowout dunes, of the Sand Hills relative to parabolic dunes elsewhere, may reflect the absence of long trailing arms (which characterize parabolic dunes), and the concentration of accretion deposits on the dune noses of the blowouts. Thus, identification of dune type in the rock record, or when unknown, may be ascertained by determining both the mean dip angle and mean angular dip deviation of laminae.
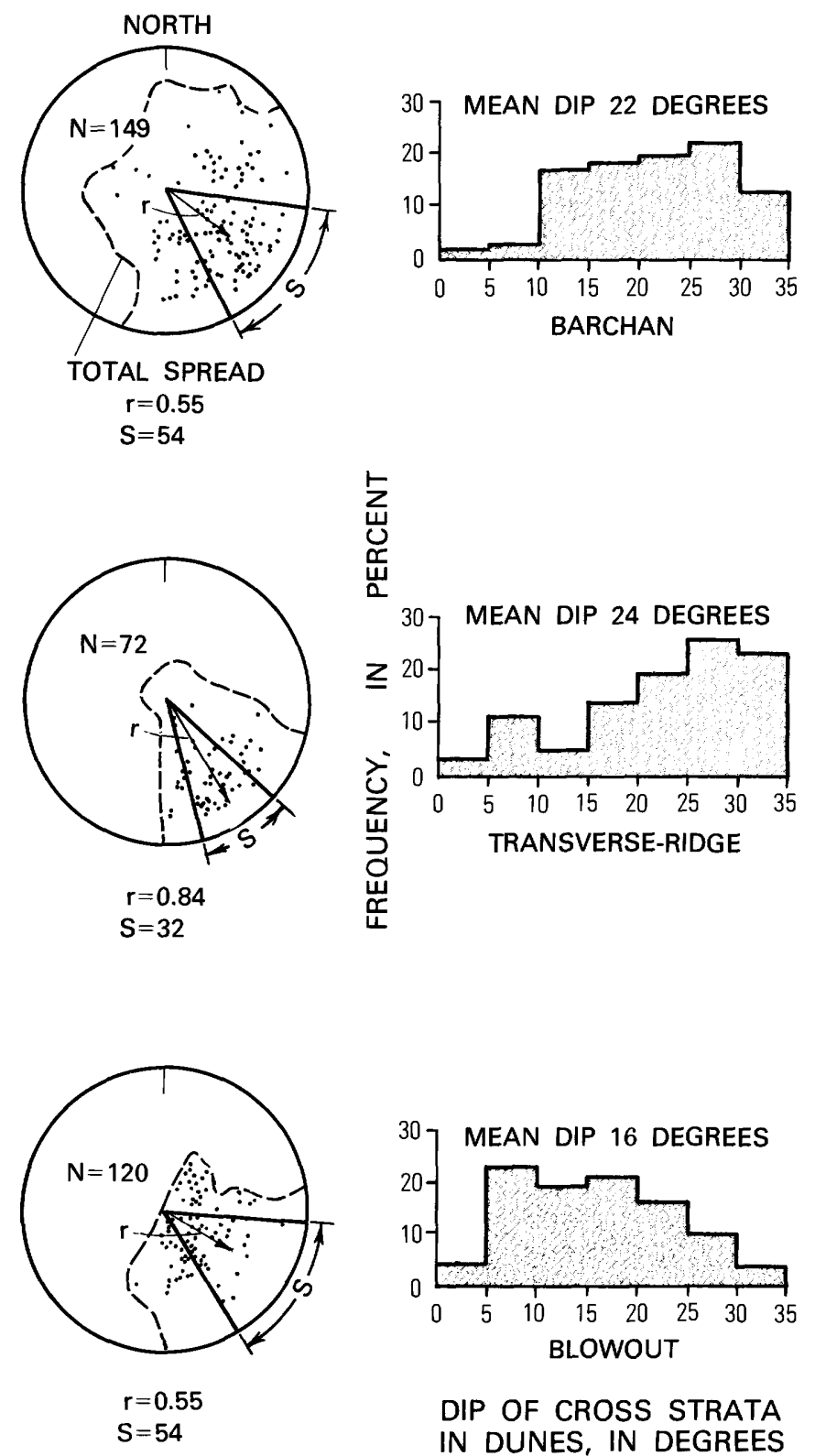

DIP OF CROSS STRATA

IN DUNES, IN DEGREES

FIGURE 6.-Mean angular deviation $(S)$ in degrees; estimate of spread of angular values around unit circle (r); and histograms of dip distribution for strike and dip data in selected barchan, transverse-ridge, and blowout dunes. Statistical computations are described in Till (1974, p. 38-43). Stereonet plots (dots) depict intersection of plunge of lamination dip with lower hemisphere. Outer margin of stereonet circle is 40 degrees.

\section{SEDIMENTARY STRUCTURES IN DUNES} PRIMARY STRUCTURES

Many excellent exposures of internal structure of the dunes were examined throughout the Sand Hills. The best exposures are along the margins of Merritt Reservoir in Cherry County, southwest of Valentine, Nebraska (loc. 17, 24, 52-54), where the dunes have 


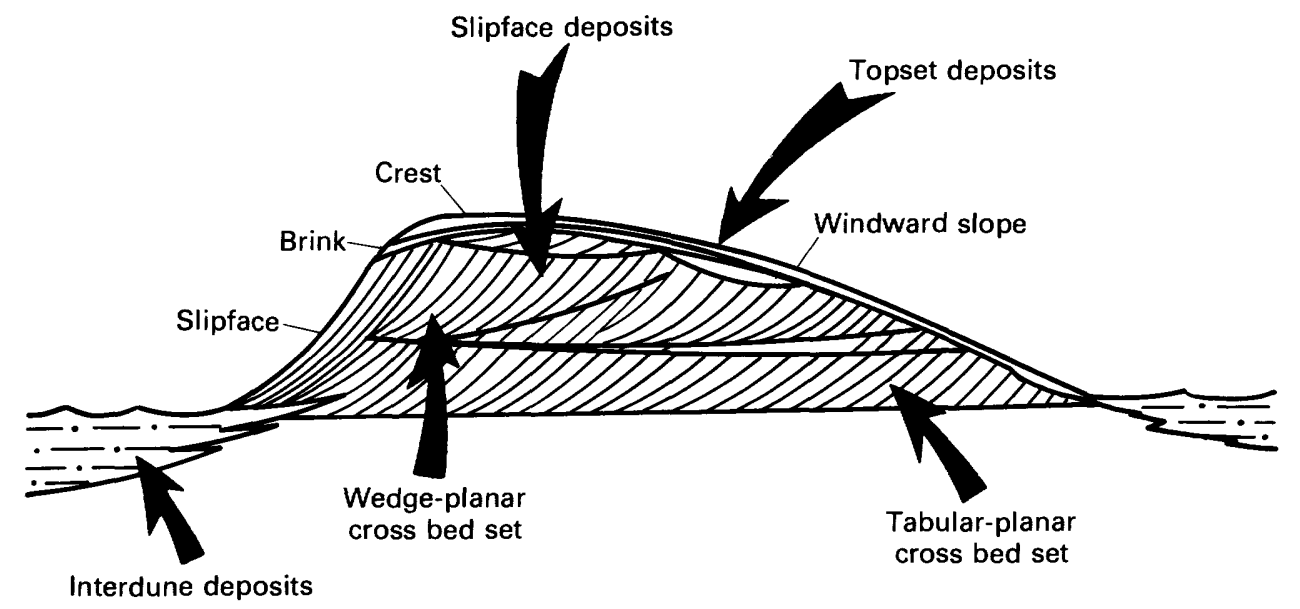

DIRECTION OF DUNE MIGRATION

FIGURE 7.-Schematic diagram illustrating terminology used in this report and internal stratification in dunes that have one slipface and migrate principally in one direction, such as barchan, barchanoid-ridge and transverse-ridge dunes in the Sand Hills.

been undercut by the Snake River. Vertical outcrops as high as $37 \mathrm{~m}$ expose the structures within en echelon barchan dunes for several kilometers along the northern margin of the reservoir (fig. 8). Exposures also were examined at many localities along the North, Middle, and South Loup, Dismal, Niobrara, Snake, and North Platte Rivers.

In general, the two types of deposits originally called "avalanche" and "accretion" deposits by Bagnold (1941) are easily recognized in dunes of the Sand Hills. Observations by a number of workers have shown that deposition on the lee side of a dune ("avalanche" deposits) may occur in a number of ways, including (1) avalanching (both slumps and grain flows; McKee and others, 1971); (2) direct fall of grains (Hunter, 1977); and (3) minor reworking of these two types of deposits by ripples oriented up and down the slipface that migrate normal to the direction of dune migration. Similarly, "accretion" deposits may form by saltation or by grain fall. "Accretion" deposits may dip either upwind or downwind. In this paper, the general descriptive terms "slipface" and "topset" are used to avoid the genetic implications of the definite processes of origin that are ascribed to "avalanche" and "accretion" by Bagnold (1941).

Topset deposits are common in dunes of the Sand Hills. Where present in barchan, barchanoid-ridge, or transverse-ridge dunes, they constitute a small percentage of the dune relative to slipface deposits; but they may still be very thick (as much as $10 \mathrm{~m}$ ) in a large dune. Dune types such as dome, blowout, and parabolic may not develop slipface deposits and may be composed almost entirely of topset deposits. Topset deposits are rarely preserved in dunes containing slipface deposits, because they are very susceptible to reworking (Reiche, 1938; McKee, 1934). Topset deposits in the Sand Hills form a relatively thin blanket over the top of a dune and may dip upwind (windward-slope deposits) or downwind (to the brink) from the crest (fig. 7). Laminae within topset beds have dips less than $25^{\circ}$, and thus do not contain avalanche structures. Laminae within topset deposits commonly are gently curving and conform to the topography of the dune or may dip at a low angle to the dune topography. Topset deposits may unconformably overlie slipface deposits.

Figure 7 illustrates the vertical sequences of deposits that can be preserved within a dune having one slipface and migrating principally in one direction. A complete vertical succession would contain slipface deposits overlain successively by downwind-dipping topset and finally upwind-dipping topset deposits (fig. $9 A$ ). However, slipface deposits may be buried by only one topset sequence or topsets may be absent (fig. 9B, $9 D$ ). The maximum observed thicknesses of upwinddipping topset beds, downwind-dipping topset beds, and slipface beds are $2.1 \mathrm{~m}$ (loc. 68), $10.4 \mathrm{~m}$ (loc. 68), and $26.2 \mathrm{~m}$ (loc. 54), respectively.

Slipface deposits in the Sand Hills are wedge- or tabular-shaped and generally comprise most of a dune. 


\section{Strike and dip of lamination,} in degrees

N. 18 W., 24 S. Strike and dip of erosional bounding surface between sets of laminations, in degrees

\section{$\longrightarrow \begin{gathered}\text { Bounding surface-Dashed } \\ \text { where estimated }\end{gathered}$}
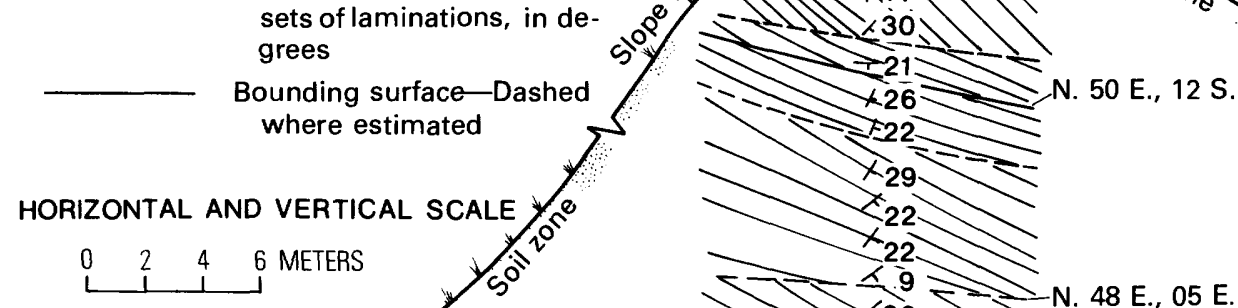

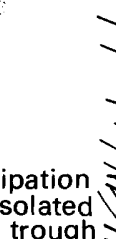
Weak dissipation
structures. Isolated
medium-scale trough

$+\quad \begin{aligned} & x_{29} \\ & \times 22\end{aligned}$

$+\quad \begin{aligned} & 22 \\ & x_{22} \\ & x_{2}\end{aligned}$

$\rightarrow-x .9$

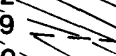

N. 48 E., $05 \mathrm{E}$.

Bounding surfaces dip

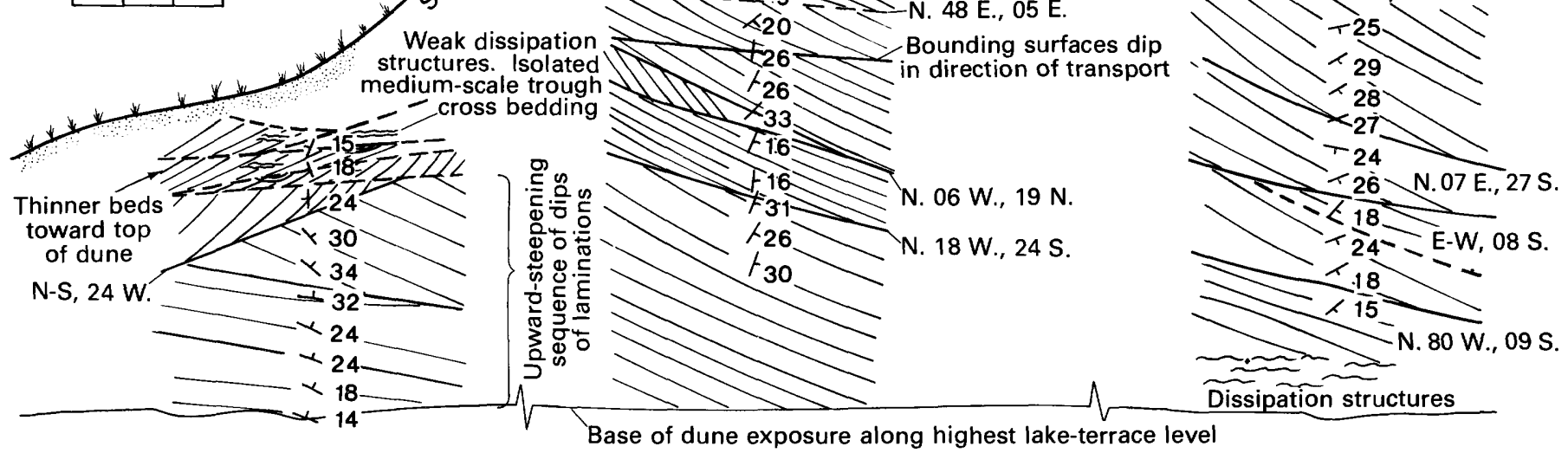

FIGURE 8.-Measured sections in en echelon barchan dunes at Merritt Reservoir (loc. 54). Sections shown in close proximity on diagram were measured on different dunes along the lake front.

Slipface deposits mostly consist of even parallel laminae, which become tangential at the lower bounding surface and are convex downward. Sand-flow lobes or toes are distinguishable near the lower bounding surface of such deposits (fig. 10A). Convex upward cross-bed sets occur in blowout and parabolic dunes, which are the result of vegetational control and general lack of slipfaces on the lee side (nose) of these dunes.

On a large scale, bounding surfaces between crossbed sets may be broadly curving and troughlike (McKee, 1966; and fig. 8); however, laminae between such surfaces meet the lower bounding surface and not the upper bounding surface and are more properly referred to as wedge-planar cross-bed sets. Although some bounding surfaces are flat, most show gentle, convex-downward curvature in the direction of dune migration, at angles less than those of enclosing laminae, and are continuous over distances of $6 \mathrm{~m}$ or more (fig. 8).

Trough (festoon) cross-bedding is uncommon in the Sand Hills (fig. 10B). The trough cross-bed set shown in figure $10 B$ resulted from reworking (scour and fill) of the uppermost part of a dune. Stacked small- to medium-scale troughs, such as those described in aqueous deposits by Harms, MacKenzie, and McCubbin (1963), were not observed in the Sand Hills dunes.

Sets of cross-strata generally are progressively thinner toward the top of a dune, their dip directions are more variable, and their dip inclinations are lower (fig. 8). The laminae within a cross-bed set generally are steepest near the top of the set (fig. 8).

A wide variety of small-scale primary structures occur in dunes of the Sand Hills. Common primary sedimentary structures include normally graded, inversely graded, and nongraded beds and laminae, and

FIgURE 9.(facing page).-Large-scale structures in dunes of the Sand Hills. $A$, Slipface deposits dipping to the left, overlain successively by downwind-dipping topset deposits and upwind-dipping topset deposits (loc. 15). B, Slipface deposits dipping to the right, not overlain by topset deposits (loc. 45). C, A "nickline" (Walker and Harms, 1972) in topset deposits is shown in a barchan dune (loc. 132). $D$, Slipface deposits overlain by downwinddipping topset deposits (loc. 77). $E$, Three sets of wedge-planar cross-bed sets, one dipping to the left, one toward the reader, and one to the right (loc. 54). The latter cross-bed set is a slipface deposit which is little affected by dissipation structures. $F$, Detail of $E$ showing dissipation structures in a cross-bed set. Note clipboard for scale in $A, D, E$, and $F$; the bar on the clipboard is $20 \mathrm{~cm}$ long. 

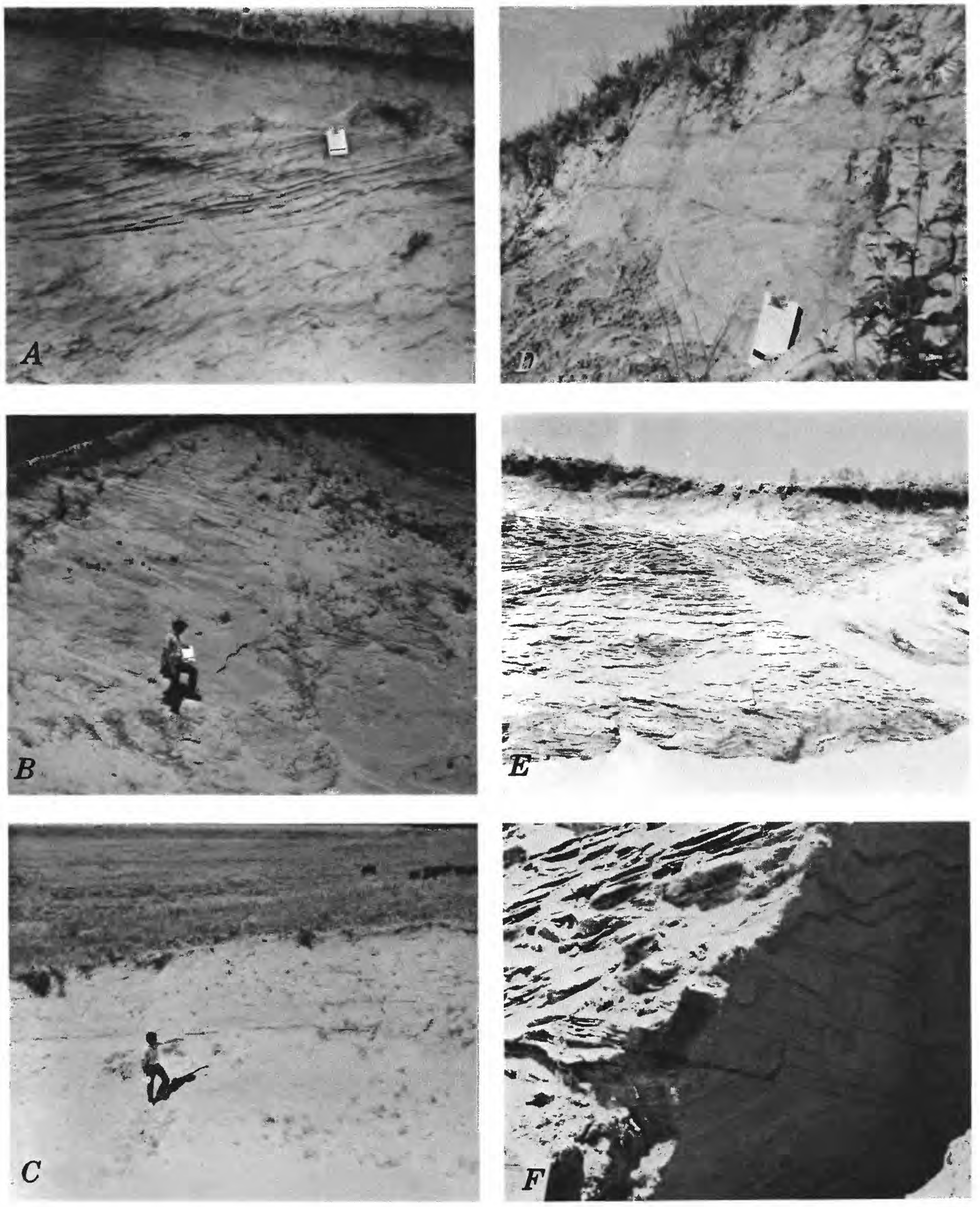

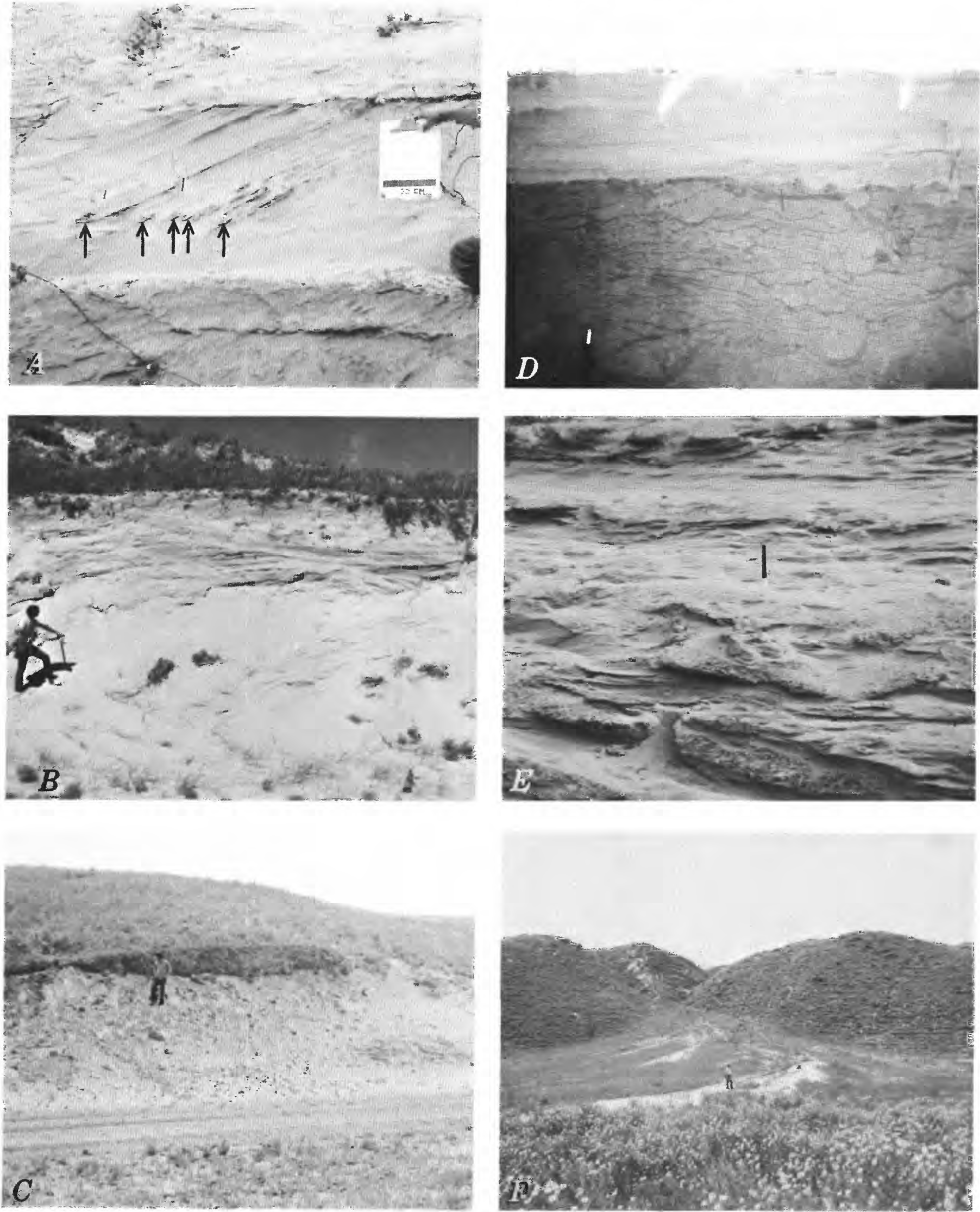
coarse-textured deposits along erosional surfaces within dunes. The few ripples observed were in flatbedded interdune deposits. Ripple laminae (McKee, $1957)$ and adhesion ripples were relatively common, the latter in interdune sediments only (fig. 10E). Graded, laminated, and unlaminated beds commonly are juxtaposed. Thinning-upward inversely graded beds occur in topset deposits (fig. 11A) and overlie thicker, normally graded beds in slipface deposits (fig. $11 B)$.

\section{SECONDARY STRUCTURES}

Secondary structures that have modified or destroyed primary dune structures, are common in the Sand Hills. Modification of primary structures ranges from slight to complete. Secondary structures include faults; contorted bedding; dissipation structures (discussed in the following section); desiccation cracks; and biogenic structures such as burrows, dikaka (root tubules), and other tubular structures. Bioturbation traces are of many sizes and shapes, and burrows are infilled in a variety of ways. For example, the large burrow in figure $12 A$ is unstratified and contains fecal pellets. The small-diameter tubular structures in figure $12 C$ have a meniscate internal structure. Burrows are both normal (fig. 12C) and oblique to bedding (fig. $12 A$ ), and some traces (dikaka) have spiral forms (fig. $12 B$ ). The surface features shown in figure $12 F$ are not burrows or dikaka but freeze-thaw-induced structures produced at the brink of an active dune which formed along the shoreline of Merritt Reservoir. Structures of unknown origin (fig. 12E) are present in flat-bedded dune sand and may reflect snow melt. Infilled desiccation cracks(?) also were observed within dunes (fig. 12D).

Contorted beds occur at the base of some slipface deposits, reflecting compressional deformation of cohesive sand similar to that described by McKee, Douglass, and Rittenhouse (1971; fig. 11D). Contorted beds caused by loading were more common in interdune deposits than in dune deposits (fig. 10D). Primary dune bedding is preserved in the contorted bed shown

Figure 10 (facing page).-Sedimentary features in dune and interdune deposits. $A$, Tabular planar cross-bed with pronounced sand-flow toes (arrows) (loc. 68). B, Rare occurrence of trough cross-bedding, in this case due to reworking (loc. 27). C, Lenticular organic-rich interdune deposit (loc. 71; sample NP-7 was taken from this deposit). $D$, Interdune deposits containing dissipation structures overlain by unaffected dune sand; contorted bedding occurs at the dune-interdune contact. Pencil is $13 \mathrm{~cm}$ long. $E$, Interbedded adhesion-rippled layers (ledges) with flat-bedded interdune sediments (loc. 68). Pen is $13 \mathrm{~cm}$ long. F, Alluvial-sand fan filling interdune (loc. 62). in figure $11 D$, but in figure $11 C$ it has been destroyed by dissipation structures. A topset bed with burrows, dissipation structures, and contorted bedding, is shown in figure $11 F$.

\section{DISSIPATION STRUCTURES}

Throughout the Sand Hills, the laminae and bedding in the upper parts of a dune exposure commonly are in various stages of modification by "dissipation structures" a term originally used by Bigarella (1975) to describe this feature in Brazilian coastal dunes. The dissipation structures from a series of dark, discontinuous, wavy bands that superficially resemble contorted bedding (figs. $9 E, 9 F, 10 D, 11 C$ ) but have a different origin. Dissipation structures are layers resulting from the concentration of fine material, and are superimposed upon original stratification. They do not result from the contortion of previously existing laminations. In the tropical climate of Brazil, Bigarella (1975) observed dissipation structures that formed in response to infiltrating waters from heavy rains causing the redistribution of colloidal material within eolian deposits.

During winter field investigations in the Sand Hills, dissipation structures were observed along the upper margins of frozen sand layers (fig. 13). Textural analyses for three samples from adjacent frozen, unfrozen, and dissipation structure layers were made using sieves (weight frequency) and a Quantimet 720 Automatic Image Analyzer (A.I.A) ${ }^{1}$. The grain shape, (area/perimeter ${ }^{2}$ ), is similar for each of the three samples (fig. 13), but texture, size, and sorting are different. The material within the dissipation structures contains 3.1 percent silt and clay, whereas the frozen sand layer contains 0.4 percent silt and clay, and the unfrozen layer contains 0.75 percent silt and clay. Another dissipation structure layer contains 16.1 percent silt and clay, compared to an adjacent unaltered layer with 2.6 percent silt and clay. Thus, dissipation structures are finer grained and more poorly sorted than are adjacent layers as determined by both weightand number-frequency data (fig. 13). The silt and clay fraction is the pan fraction of the sieve that is predominantly clay as determined by the Automatic Image Analyzer following disaggregation of this fraction with an ultrasonic device.

A source of clay which may become concentrated within dissipation structure layers is present within the dunes as clay coatings on sand grains. These coatings are mainly montmorillonite with some mixed-

${ }^{1}$ Use of trade or company names is tor descriptive purposes only and does not constitute an endorsement of the product or company by the U.S. Geological Survey. 

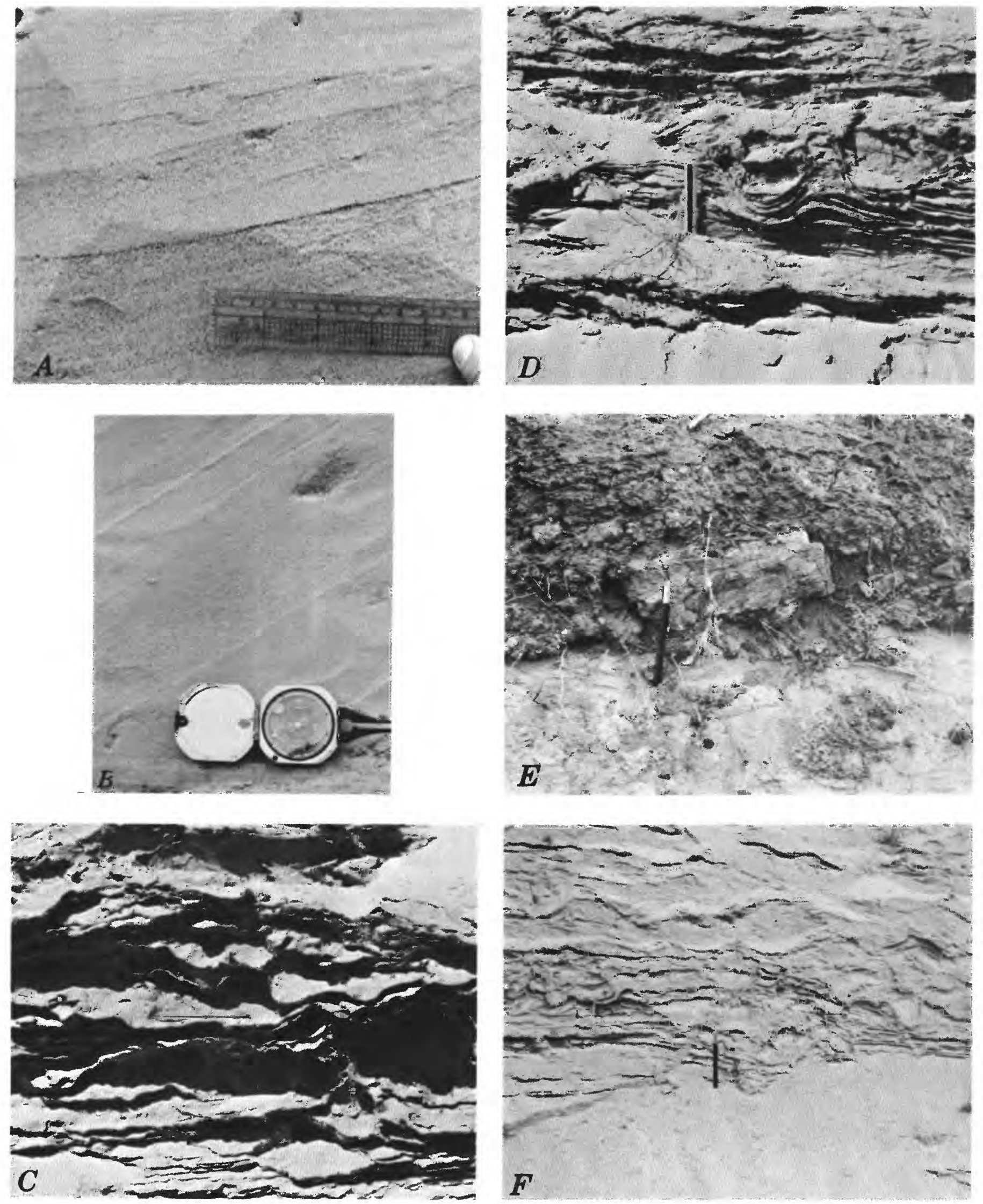
layer montmorillonite-illite as determined by X-ray diffraction and scanning electron microscope techniques. Dissipation structures most commonly occur in the upper part of an outcrop and along the upper margin of frozen sand layers. Infiltration of water may concentrate clay preferentially in or along less permeable layers within the dune sands. Frozen sand layers may form a barrier to such infiltration and cause clay to be deposited above them. After the frozen layer melts, the dissipation structure (layer) is less permeable than surrounding layers due to increased clay content. This process would promote the continued deposition of clay in and adjacent to the dissipation structure. The reduced permeability in dissipation structure layers relative to surrounding unaffected layers is discussed in the Sedimentary Petrography section of this chapter.

\section{INTERDUNE DEPOSITS}

A continuing question in eolian studies is whether interdune deposits are extensive or strictly local (McKee and Moiola, 1975). Interdune pond deposits and waters comprise a total of $266.33 \mathrm{~km}^{2}$ in the Sand Hills (Steen, 1961). Interdune pond deposits that crop out in the Sand Hills seem to be isolated and lenticular at localities 2, 60, and 71 , where they intertongue with dune sand. A 2,590- $\mathrm{km}^{2}$ area of enclosed drainage and alkaline interdune pond deposits in the western Sand Hills was drilled extensively in search of potash during World War I (hachured area, fig. 1). In test holes, two or three buried hardpan layers were separated by sands containing alkaline water, but no continuous hardpan horizon in the western part of the Sand Hills was found (Condra, 1918; Bradley and Rainwater, 1956; fig. 3, this chapter).

For this study, samples from three interdune deposits were collected for paleontological, palynological, and organic-geochemical analyses. Two samples are from an alkaline interdune deposit in northwestern Cherry County (NS-2, 3, loc. 2), and the third sample is from a lenticular, organic interdune deposit in Hooker County (NP-7, loc. 71). The results of the analyses of mollusks from these samples are

FIGURE 11 (facing page).-Small-scale structures in the Nebraska Sand Hills. $A$, Inversely graded, thinning-upwad beds in topset deposits (loc. 116); centimeter rule shown for scale. $B$, Normally graded slipface deposits underlying deposits shown in $11 \mathrm{~A}$ (loc. 116). $C$, Intense development of dissipation structures; relict laminae near bottom of photograph (loc. 52). $D$, Contorted bed at base of slipface deposit (loc. 52). $E$, Brecciation of interdune sediment (loc. 71). $F$, Intense disruption of topset deposits by contorted bedding, dissipation structures, tensional fault (just left of pencil), and meniscate burrow (loc. 70). discussed in chapter B, and the analyses of diatoms, ostracodes, and pollen for the same samples are discussed in chapter $\mathbf{C}$.

Interdune deposits in the Sand Hills differ from nearby dune sands in color, thickness, texture, internal structures, and composition. Interdune pond deposits are commonly richer in organic matter than are dune topset and slipface deposits (fig. 14); they are dark gray to black, whereas the dune sands have lighter hues. Thickness of interdune sediments in the Sand Hills ranges from a few meters in surface exposures (fig. $10 \mathrm{C}$ ) to $15 \mathrm{~m}$ in some core samples (see chapter C). Nearby dunes have thicknesses of 60-90 m. The depth of organic silt, sand, and other sediment was $6.5 \mathrm{~m}$ (Watts and Wright, 1966), and $5 \mathrm{~m}$ (Sears, 1961). Interdunes with similar deposits were cored to depths of 3.5 $\mathrm{m}$ in Krause and Jesse Lakes in Sheridan County in 1953 (H. S. Tourtelot, oral commun., 1976).

Interdune deposits generally are finer grained and more poorly sorted than are dune deposits. (Interdune samples shown in figure 16 are plotted for their sand fractions only; compare with figure $15 C$ which includes the silt and clay fractions; also see McKee and Moiola, 1975.) The adverse effects of interdunes as permeability barriers on sandstone reservoirs (for both water and petroleum) are described by Bradley and Rainwater (1956).

Horizontal to subhorizontal laminae are numerous in the interdune deposits of the Sand Hills. Interdune deposits commonly contain adhesion ripples (fig. 10E), dissipation structures, and convolute bedding (fig. 10D). The interdune sample from Hooker County (NP-7) was analyzed for organic content by combustion and a thermal analysis-gas chromatography technique. The results of analyses of coarse- and fineorganic fractions by G. E. Claypool (written commun., 1975) are shown in table 1.

TABLE 1.-Organic analyses of interdune sample NP-7

\begin{tabular}{|c|c|c|c|c|}
\hline & \multicolumn{2}{|c|}{$\begin{array}{c}\text { Carbon (in } \\
\text { weight percent) }\end{array}$} & \multicolumn{2}{|c|}{ Oil yield } \\
\hline & Total & Organic & Galiton & Weight percent \\
\hline $\begin{array}{l}\text { Whole rock .............. } \\
\text { Organic concentrates: }\end{array}$ & 1.71 & 0.9 & 0.25 & 0.1 \\
\hline 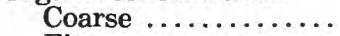 & $\ldots$ & $\ldots \ldots$ & 14.1 & 5.4 \\
\hline Fine......... & $\ldots \ldots$ & $\ldots \ldots$ & 6.7 & 2.6 \\
\hline
\end{tabular}

The sample was heated from $30^{\circ}$ to $355^{\circ} \mathrm{C}$ and produced 8-10 major hydrocarbon compounds distilled from the organic matter. A second analysis was performed on material evolved from the sample at temperatures of $355^{\circ}-800^{\circ} \mathrm{C}$ (fig. 14). The decomposition of the solid organic matter during the second analysis produced the whole range of normal paraffin hydrocarbons, and, thus, could produce petroleum 

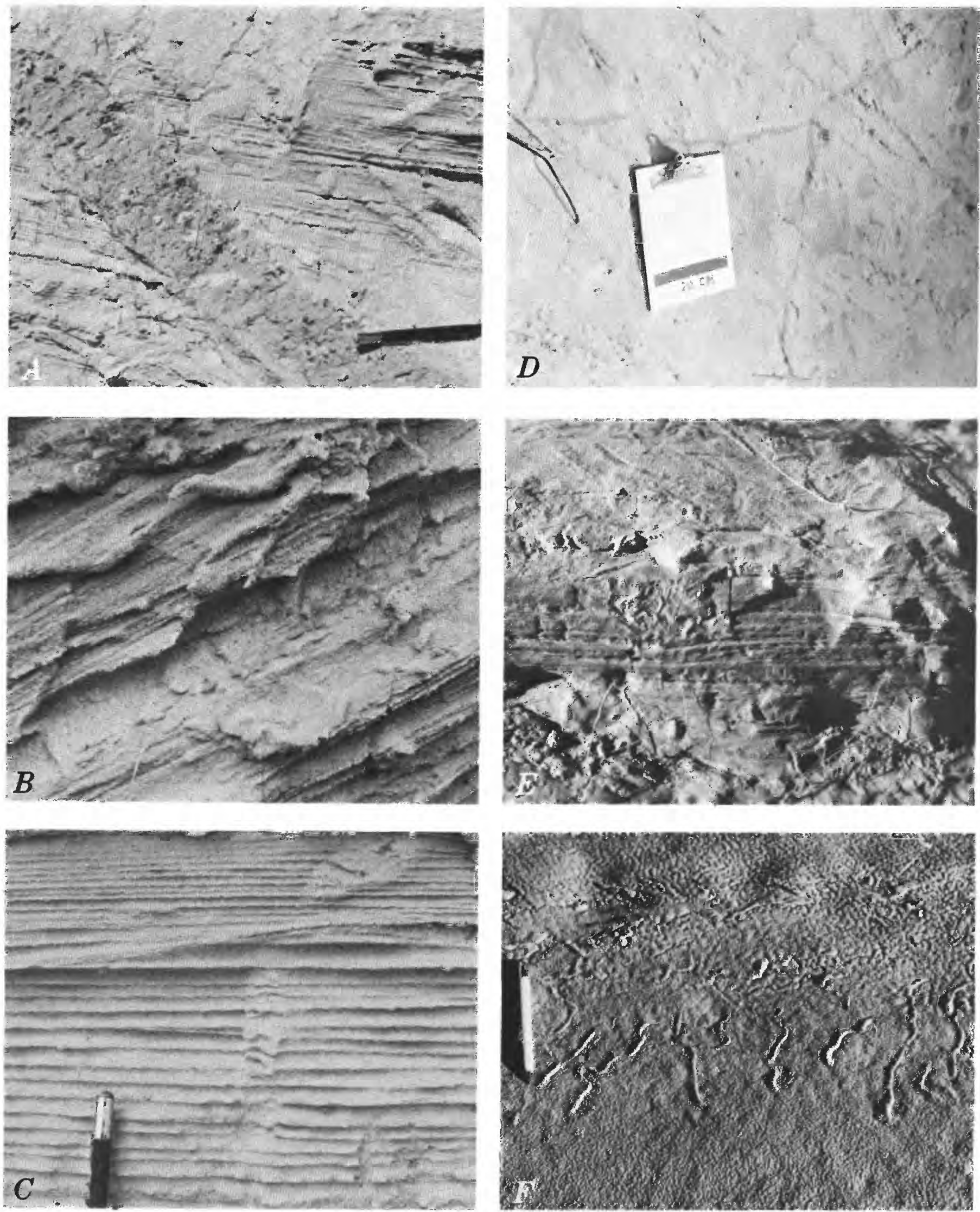

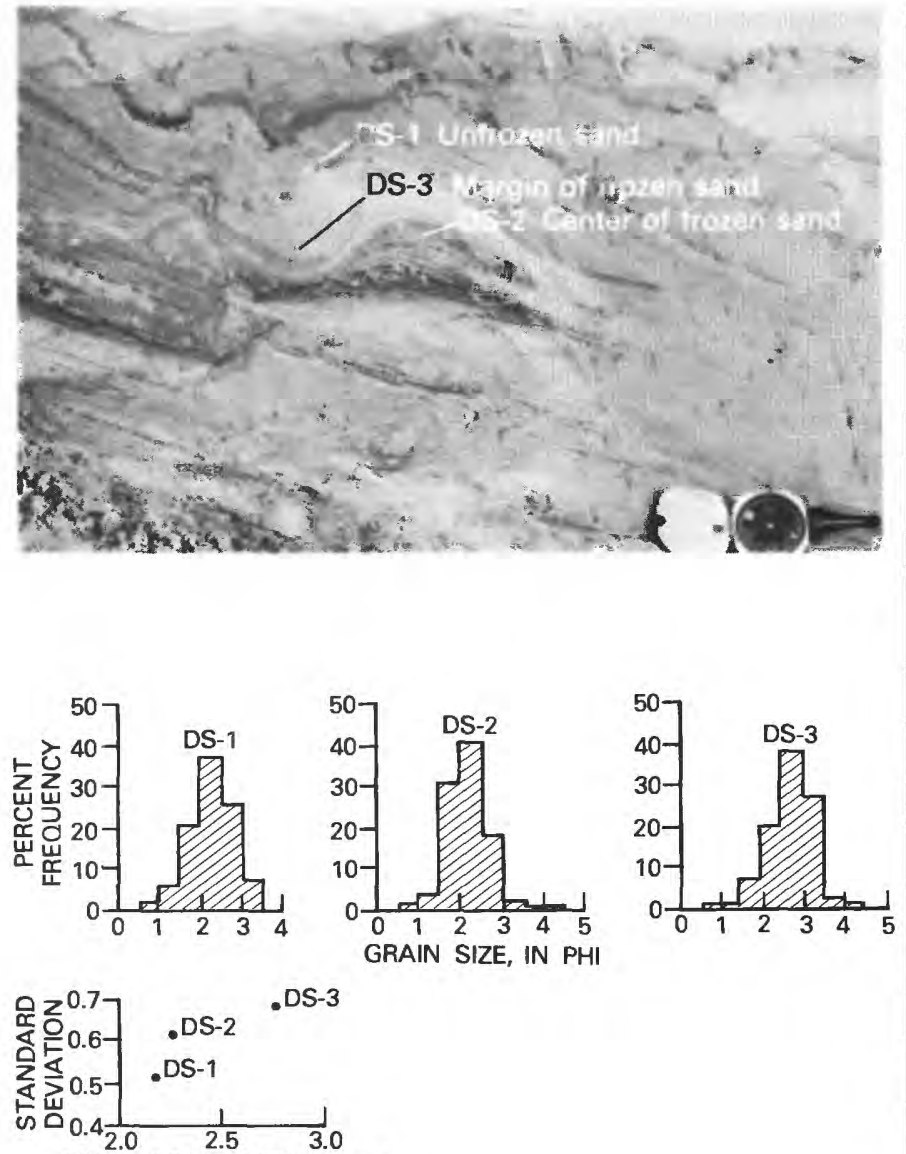

MEAN GRAIN SIZE, IN PHI
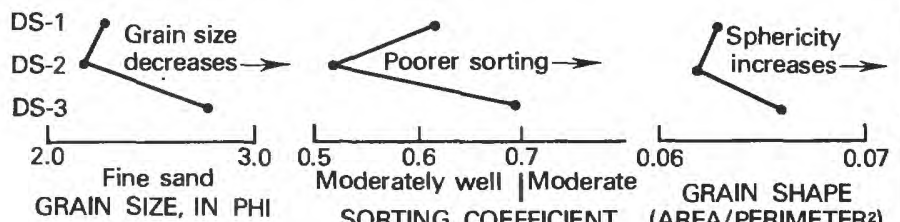

FIGURE 13.-A dissipation structure along the upper margins of a frozen sand layer. Mean grain size, sorting, and shape factors for three adjacent samples are shown. Sample DS-3, from the margin of the frozen sand, is finer grained and more poorly sorted than either unfrozen sand (DS-1) or sand from the center of the frozen layer (DS-2).

Figure 12 (facing page).-Secondary sedimentary structures. $A$, Fecal pellets within unstratified, filled, large-diameter burrow (loc. 52). B, Spiral bioturbation traces and plant molds; area shown is $12 \mathrm{~cm}$ across (loc. 116). $C$, Small-diameter meniscate burrow crossing a preserved ripple (loc. 52). $D$, Infilled desiccation cracks exposed in bottom of blowout near base of transverse dune (loc. 68). E, Collapse structure(?) in flat-bedded dune sand (loc. 54). $F$, Top view of freeze-thaw structure produced by melting of a thin layer of snow beneath a 5-cm-thick layer of sand. upon burial and heating (G. E. Claypool, written commun., 1975) (fig. 14).

The pyrolysis product of the interdune sediment (sample NP-7) is comparable to hydrocarbons produced from lacustrine deposits of the Eocene Green River Formation in the western United States. Pyrolysis products from interdune sediments and from the Green River Formation may have a common organic source; namely, nonmarine algae (G. E. Claypool, written commun., 1975). The presence of 326 species of algae in the Sand Hills lakes has been established by Anderson and Walker (1920). The pyrolysis products of interdune sediments resemble saturated hydrocarbons in crude oils from the Pineview Field in Wyoming, which produces from the Triassic(?) and Jurassic(?) Nugget Sandstone, considered to be, in part, an eolian deposit.

Using a pyrolytic oil yield for the coarse organic concentrate of $14.1 \mathrm{gal} / \mathrm{ton}$ (60 liters/metric ton) and a 0.9 percent organic carbon content for the whole rock will give a pyrolytic oil yield for the original sediment sample of about $0.25 \mathrm{gal} /$ ton (1.07 liters/metric ton). If a density of $0.08 \mathrm{lb} / \mathrm{in}^{3}\left(2.2 \mathrm{~g} / \mathrm{cm}^{3}\right)$ is assumed, then 436 unit volumes of source rock would be required to produce one unit volume of oil. If expulsion of oil is inefficient, then 2 to 4 times more rock volume (872 to 1,744 unit volumes) would be required to produce one unit volume of oil (G. E. Claypool, written commun., 1975).

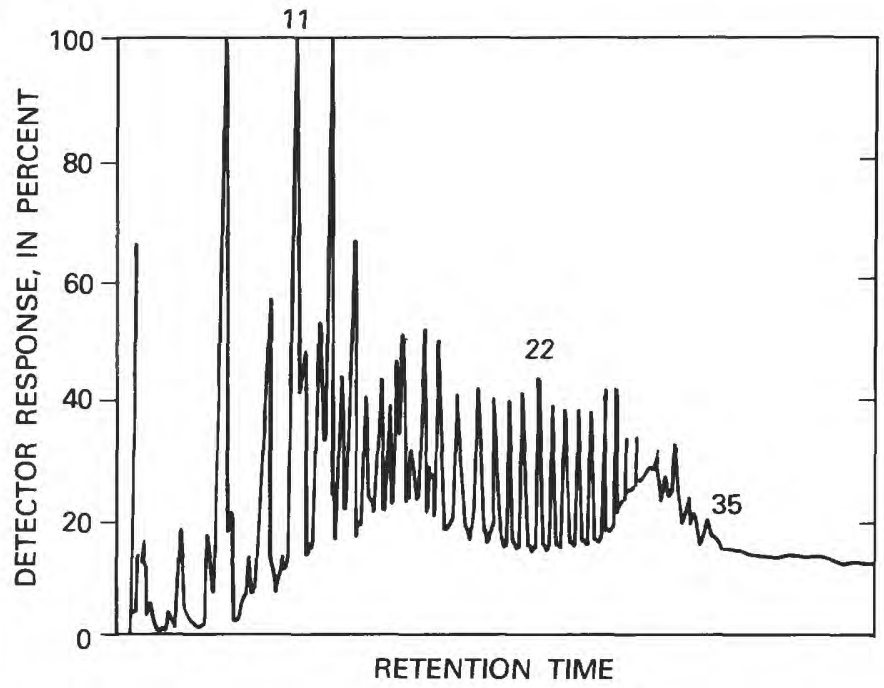

FIgURE 14.-Gas chromatogram of Nebraska Sand Hills interdune deposit (NP-7, loc. 71). The sample was heated from $355^{\circ}$ to $800^{\circ}$ C. Numbers along selected peaks refer to the number of carbon atoms per molecule of normal-paraffin hydrocarbons. The whole range of normal-paraffin hydrocarbons, both oil and natural gas, was generated. 

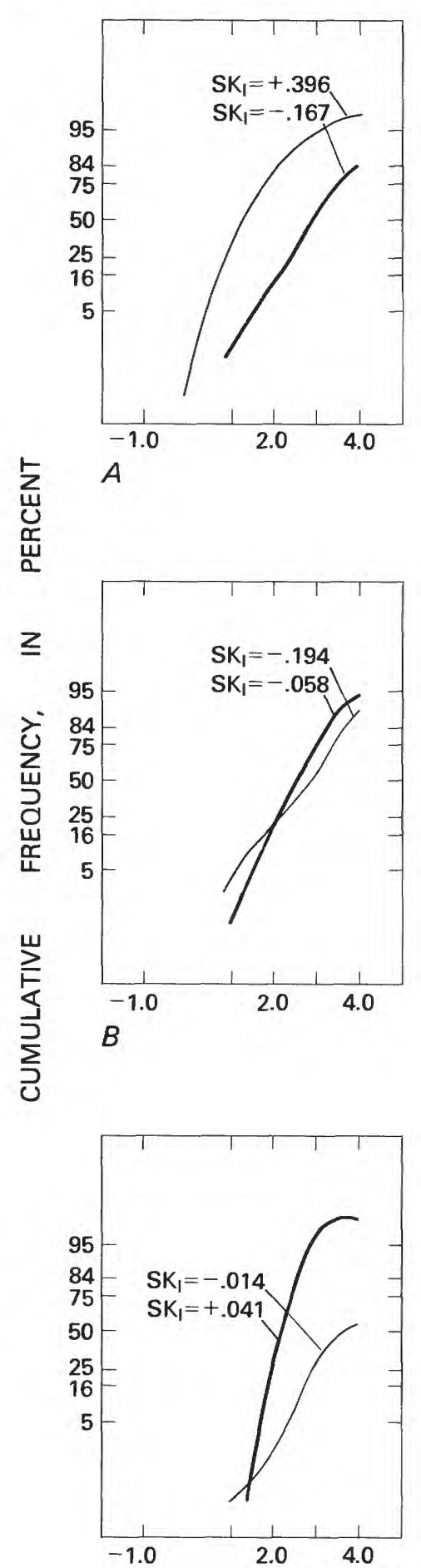
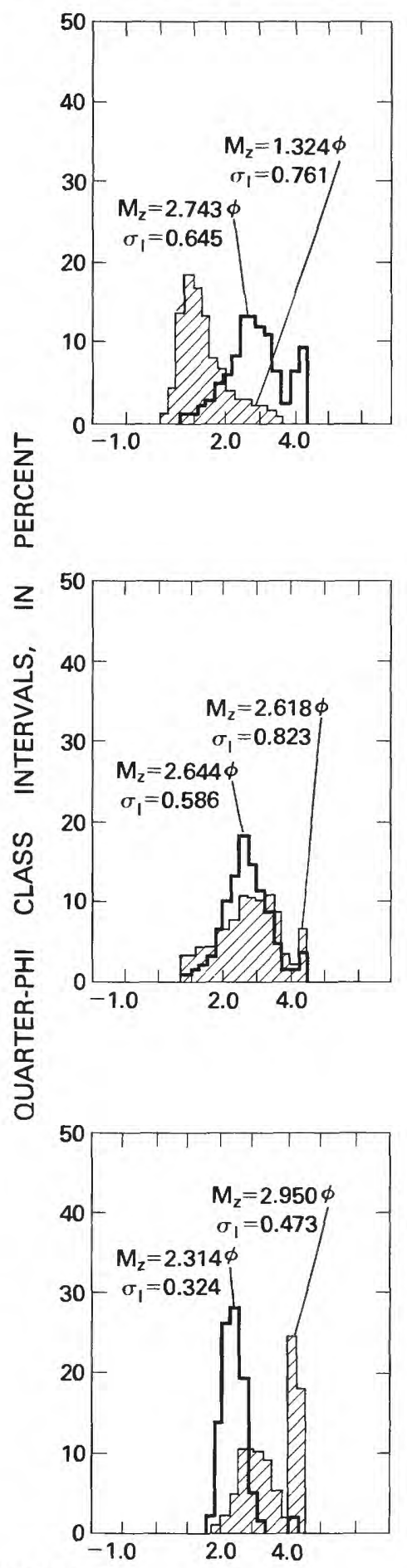

GRAIN SIZE, IN PHI $(\phi)$

\section{EXPLANATION}

$\geq 4.0$ Silt and clay fraction combined

SK Skewness

$M$ Mean grain size

$\sigma$ Standard deviation
Figure 15.-Textural contrasts of eolian sand samples. $A$, Adjacent topset deposits, loc. 75; a light-colored layer (thin line on cumulative curve, patterned area on histogram) adjacent to a darkcolored layer that contains dissipation structures (thick line). B, Loc. 40; topset deposits (thin line, patterned histogram) compared with slipface deposits (thick line). $C$, Poorly sorted, sandy mud from interdune deposit (thin line, patterned histogram, loc. 25) versus very well sorted slipface sand (thick line, loc. 10). Cumulative frequency curves were recalculated on the sand fraction if either gravel or pan fraction was greater than five percent. 


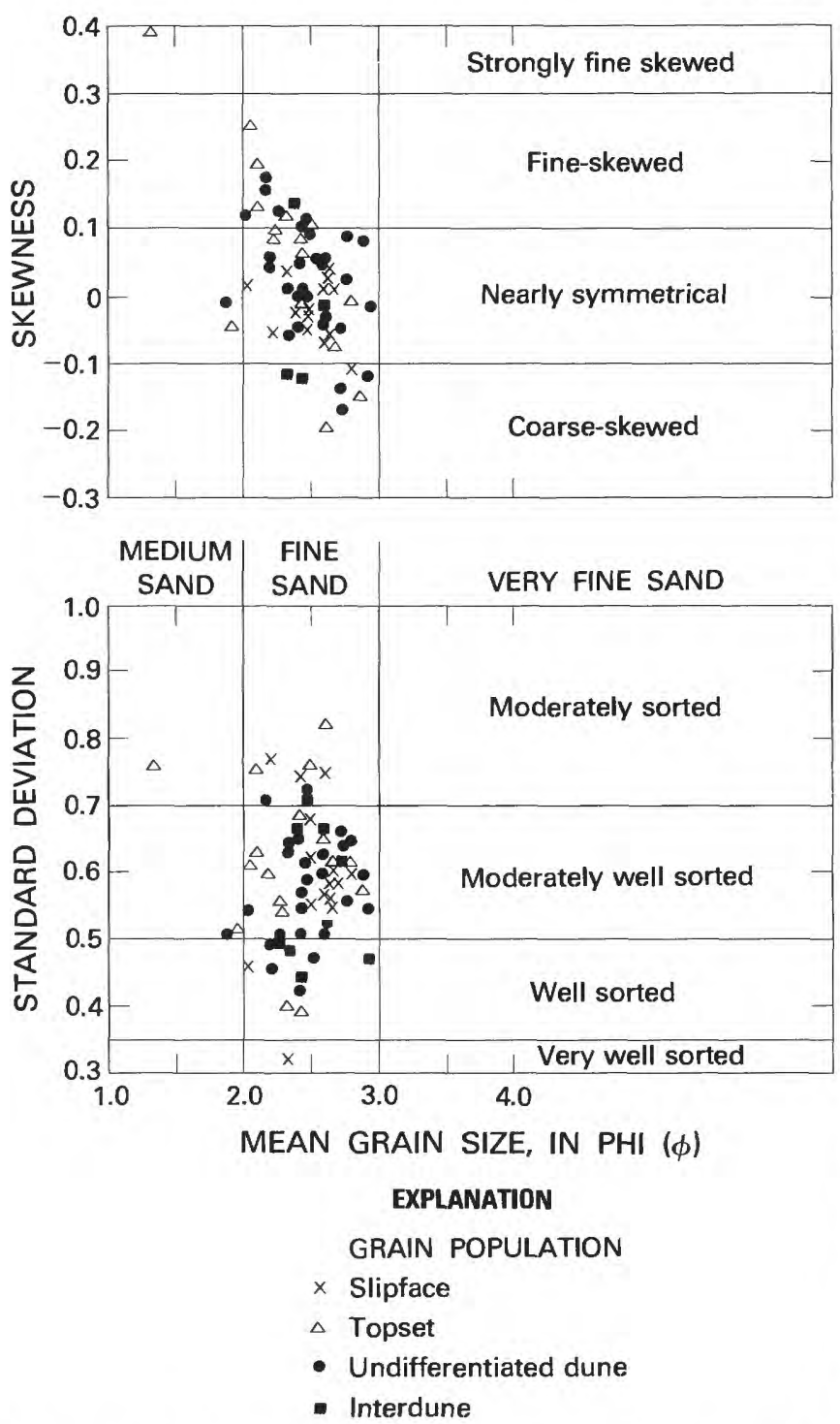

Figure 16.-Textural parameters of 93 eolian-sand samples divided into topset, slipface, undifferentiated dune, and interdune populations. Values for interdune samples reflect the sand fraction only.

An indigenous hydrocarbon source for the eolian Nugget Sandstone in western Wyoming has been proposed by Picard (1975). He found that many reservoirs in the Nugget are not filled to their spill points; that is, the effective pay zone is much less than subsurface closure. He further suggested that the characteristic of the Nugget oils indicate an indigenous source; namely, lacustrine intervals in the basal part of the Nugget Sandstone. Interdune sediments in the Nebraska Sand Hills could possibly provide upon burial a source of petroleum for nearby surrounding reservoir rocks.
Thus, these interdune deposits are possible analogs for source rocks in the Nugget.

\section{DEGRADATIONAL PROCESSES IN THE SAND HILLS}

Although much of the Sand Hills region is covered by a protective mantle of grass, the forming of soil, erosion by wind and water, and mass wasting are continually modifying the landscape and internal structures of the dunes.

Wind erosion produces parabolic dunes and blowout dunes (previously described) and, in general, reduces the relief of the old dune topography. In some places, wind erosion results in yardangs, and, in the western Sand Hills, the denudation of dry salt-encrusted interdunes in summer.

Water erosion probably is the most important cause of landscape alteration. Dissection of the steeper lee slopes and slipfaces of dunes by gullies is a common occurrence and deposition from these gullies creates alluvial fans, particularly in front of the dune slipface (fig. 10F). The sand deposited as alluvial fans was originally accumulated through eolian processes and has been moved only a short distance by water. When carried to extremes, the dissection results in slumping. Abundant rainfall has caused the formation of organicrich interdune ponds and the development of thin soils on the dune sands. Thus, both aqueous and subaerial processes are currently eroding the dunes and infilling the topographically low interdune areas.

\section{SEDIMENTARY PETROGRAPHY}

A suite of 93 samples from topset, slipface, undifferentiated dune, and interdune deposits was collected from below the soil zone in outcrops throughout the Sand Hills. The samples were sieved on $1 / 4 \phi$ intervals; and graphic measures of mean grain size $\left(M_{z}\right)$, sorting $\left(\sigma_{I}\right)$, skewness $\left(S K_{I}\right)$ and kurtosis (both $K_{G}$ and transgraphic kurtosis $K_{G}^{1}$ ), as defined by Folk (1968), were determined.

The analysis of 93 sand samples showed that there is as much textural variation from one bed to another within a single dune as among dunes in widely separated localities (fig. 15A). One layer of topset beds (fig. 15A) is a moderately sorted, strongly fine skewed, medium-grained sand with a silt and clay content of 2.6 percent. The overlying topset bed, containing incipient dissipation structures, is noticeably darker and is a moderately well sorted, coarse-skewed, finegrained sand with a silt and clay content of 16.1 per- 

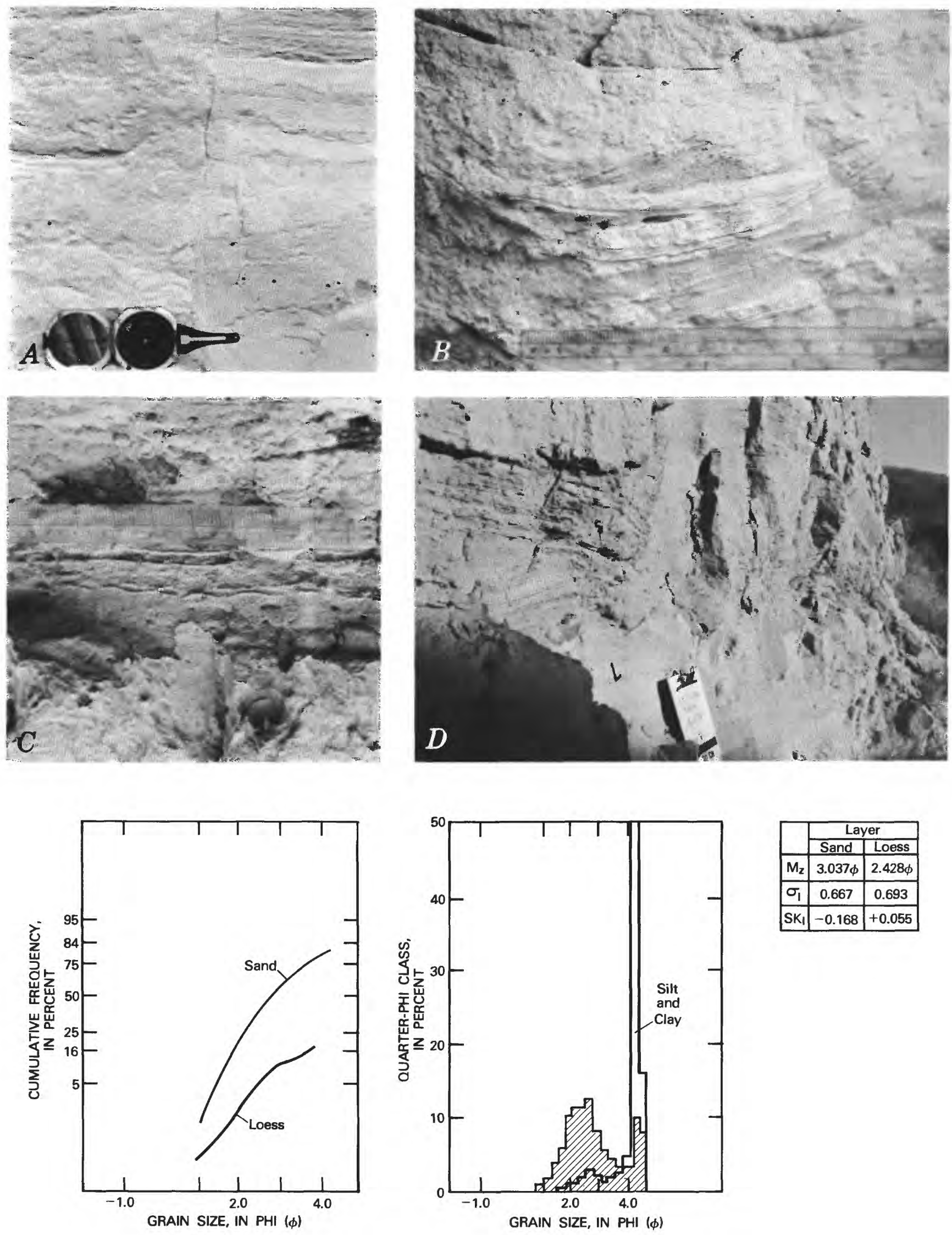

\begin{tabular}{|c|c|c|}
\hline & \multicolumn{2}{|c|}{ Layer } \\
\cline { 2 - 3 } & Sand & Loess \\
\hline $\mathrm{M}_{\mathbf{z}}$ & $3.037 \phi$ & $2.428 \phi$ \\
\hline$\sigma_{1}$ & 0.667 & 0.693 \\
\hline $\mathrm{SK}_{1}$ & -0.168 & +0.055 \\
\hline
\end{tabular}


cent. Textural differences are also found between topset and slipface sand (fig. 15B). The extreme sorting differences between very poorly sorted sandy interdune mud and very well sorted slipface sand are shown in figure $15 \mathrm{C}$. The sample of slipface sand shown in figure $15 C$ is the only very well sorted sand sample of the entire 93-sample suite.

The plot of mean grain size versus sorting demonstrates that the samples are predominantly finegrained, moderately well sorted sands (fig. 16). The plot of skewness versus mean grain size shows a wide distribution of values, both positive and negative (fig. 16), and is a characteristic of other inland dune fields (Ahlbrandt, 1974). Kurtosis values were widely scattered and will not be presented.

Seven thin sections were cut from $2.5-\mathrm{cm}$-diameter plugs taken in the field for permeability tests. The field sampling procedure consisted of a standard softsediment-permeability sampling device provided by Core Laboratories, Inc. After the permeability of a sample was determined, the plug was injected with blue epoxy, thin-sectioned, and stained for K-feldspar; 600 grains per slide were counted.

The sand that composes both dune and interdune deposits is predominantly a feldsarenite as defined by Folk, Andrews and Lewis (1970). The sandy interdune samples have more feldspar (36.1 percent feldspar average for four interdune samples) than the dune sands (19.3 percent feldspar average for three samples). The detrital components of these eolian deposits in decreasing frequency include quartz (50-75 percent), feldspar (about equal amounts of K-feldspar (9-25 percent) and plagioclase (5-24 percent)), chert (3-9 percent), rock fragments (1-4 percent), and clay (trace-4 percent in dune sand, 2-32 percent in interdune sand). Montmorillonite clay coatings occur on grains of all compositions.

The permeability of 13 dune-sand samples ranged from 2.4 to 9.9 darcies (D). Large permeability differences were found during a bed-to-bed comparison. For example, analysis of adjacent samples from a topset deposit showed 5.1-D permeability for a fine sand, whereas the medium sand bed below had 9.4-D permeability (see fig. 15A). A similar contrast was present in slipface deposits; a fine sand bed had 2.8-D

FIGURE 17 (facing page).-Sedimentary features in loess (loc. 128). $A$, Loess deposits before smoothing and brushing, left, and after, right. $B$,Scour-and-fill features in loess (numbers on scale in centimeters). $C$, Low-index ripples in sandy loess. $D$, Scour feature along base of sand intercalated in loess. Textural analyses for a sand sample within a loess sequence and loess sample subjacent to the sand in $D$. Cumulative frequency curves were recalculated on the sand fraction if either gravel or pan fraction was greater than five percent. permeability whereas a medium sand bed $5.1 \mathrm{~cm}$ below had 6.6-D permeability. Although the internal permeability contrasts initially seemed of little importance, their influence on the development of secondary structures was recognized later. The finer grained, less permeable layers were the first to develop dissipation structures, as discussed in a preceding section. The differential cementation of laminae observed in eolianites may relate to these initial permeability (and presumably porosity) contrasts.

\section{LOESS DEPOSITS}

The stratigraphic relationship of the loess sequence to the eolian deposits in the Sand Hills (fig. 1) was determined in a subsidiary study. After a summer of field investigations, an aerial reconnaissance showed the closest proximity of dune and loess deposits to be in the vicinity of Arnold, Nebraska, in Custer and Logan Counties. Subsequent field investigations of these areas indicate that the dunes overlie the eroded remnants of the loess. For example, dunes occur in the valley below the cliffs of the loess hills northwest of Arnold and also on top of the cliffs (fig. 3, section $D-D$ ). Whereas datable material to relate the two was not available, the only evidence that directly related the loess and eolian deposits was the presence of sands intercalated within the loess section. Lugn $(1935,1960$, 1962, 1968), Wehrman (1961), and Reed and Dreeszen (1965) considered these sands to be eolian, and assigned these deposits to the Peorian Loess and Peorian Dunesand and the Bignell Loess and Bignell Dunesand.

Although loess has generally been described as structureless, we observed loess in this area with both large- and small-scale sedimentary structures intercalated with sequences of structureless loess. Largescale laminations inclined as much as $10^{\circ}$ with an apparent dip to the south were in loess at localities 120 , 128, 129 in Custer and Logan Counties. After scraping an outcrop with a machete and then brushing it with a soft-bristled paint brush, numerous small-scale structures were apparent (fig. 17A). Small-scale structures such as high-amplitude ripples (fig. $17 B$ ), scourand-fill structures with well-preserved foresets (fig. $17 C$ ), parallel to discontinuous wavy nonparallel laminae, and small-scale channel-fill structures were present. Structureless loess occurred at many localities where burrows and dikaka (oxidized root tubules) had destroyed primary bedding. Mollusks were present in such sequences as further described by Frye, Willman, and Glass (1968) and Frankel (1957a, b).

Sands intercalated in the loess may reflect only locally reworked deposits; but, where we observed them, 
they are not eolian deposits and are most probably fluvial deposits. The scour along the base of one such sand bed is shown in figure $17 D$ (note the local relief and abrupt textural change at the loess-sand contact). Within the sand deposits are small-scale structures that confirm a subaqueous origin. Figure $17 D$ shows a channel, which is locally filled with trough crossbedding and contains high-amplitude ripples (fig. 17C). The sands grade vertically upward into loess with intercalated sand and loess, and above these only loess (fig. $17 D$ ). The correlation of such sands within the loess sequence is difficult, as is illustrated in figure 18 where three test holes extend through a loess section (Section $E-E$ '). Sand occurrence is sporadic and therefore suggestive of channel-sand development.

Lugn (1968) and Wehrman (1961) suggested that loess and dune deposits were intercalated. However, our observations in Logan and Custer Counties suggest that younger dune sand unconformably overlies loess deposits: (1) sedimentary structures in loess out- crops in the Arnold area (Logan and Custer Counties) demonstrate that those sands intercalated in the loess were deposited in a subaqueous, not subaerial, environment; (2) sand dunes override the eroded loess topography in the Arnold area; (3) a twofold stratigraphy in the dune sand cannot be traced laterally through the Sand Hills, as evidenced by analysis of test- hole data (figs. 3, 18). A similar relationship of younger dune sand mantling loess deposits that are "remarkably free of interbedded dune sand" is noted by Brice (1964, p. D9) in the Brewster area (Blaine County). He further noted that dune sand overlies valley fill of Peoria (Illinoian) age. We suggest that Lugn's (1935) original term for the dune sand in the Sand Hills, the Sand Hills Formation, be used (although not adopted by the U.S. Geological Survey ${ }^{2}$ ) until the problems just mentioned are resolved.

${ }^{2}$ Since this paper was originally completed in 1976 , new radiometric age determinations of sediment beneath the Sand Hills Formation by University of Nebraska personnel confirm a Holocene age for the Sand Hills (James B. Swinehart II, oral commun., 1978).

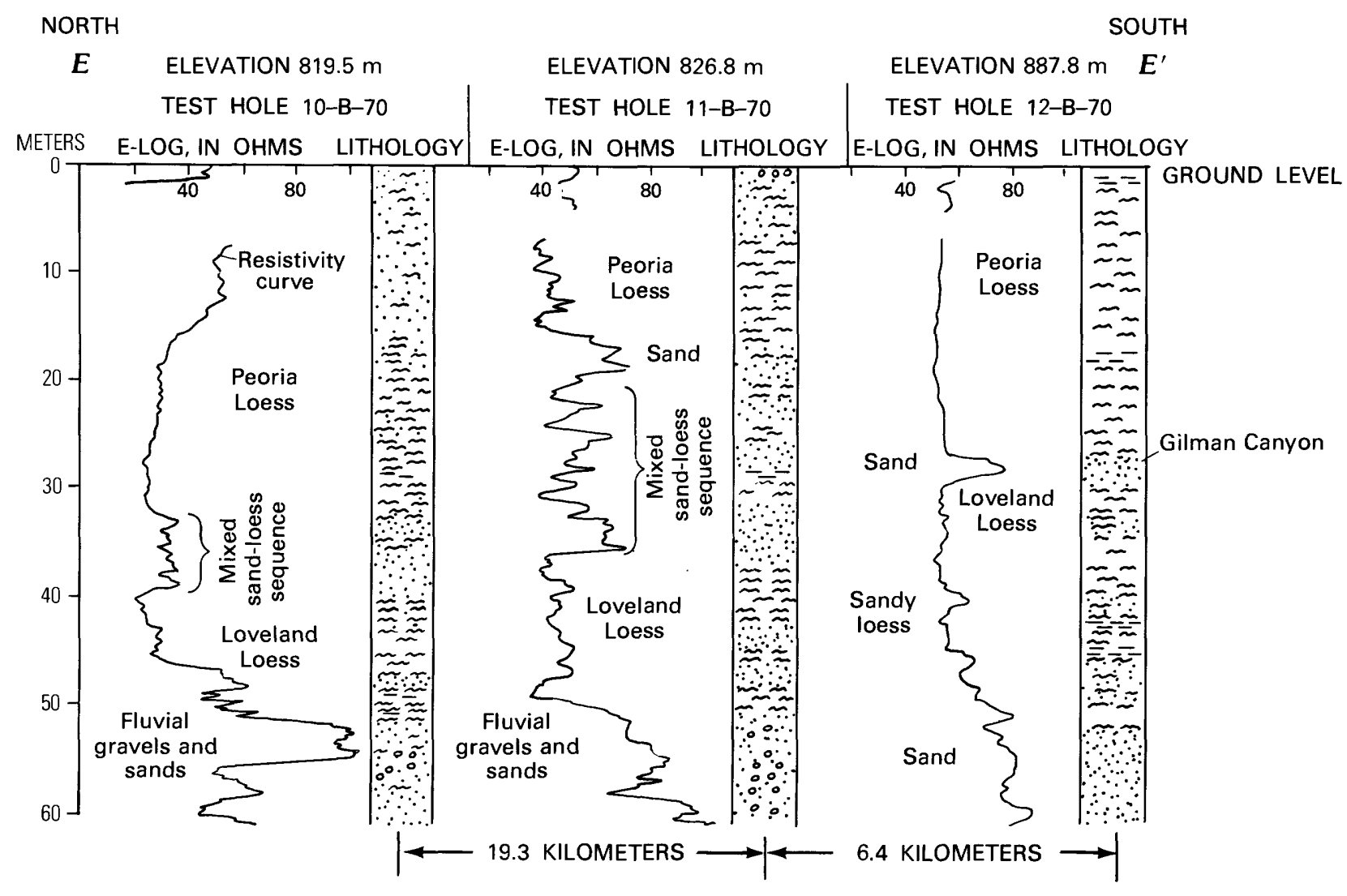

\section{EXPLANATION}




\section{ACKNOWLEDGMENTS}

Textural analyses were graciously provided by R. J. Moiola and W. Phillips of Mobil Research and Development Corporation. This paper was improved by the careful reviews of James B. Swinehart II and Vincent $H$. Dreeszen of the Conservation and Survey Division of the University of Nebraska, Ray Bentall, and Edwin D. McKee of the U.S. Geological Survey, and James R. Steidtmann of the University of Wyoming. The director and staffs of the Nebraska Geological Survey and the Conservation and Survey Division of the University of Nebraska were most helpful during all phases of this study.

\section{REFERENCES CITED}

Ahlbrandt, T. S., 1974, The source of sand for the Killpecker sanddune field, southwestern Wyoming: Sed. Geology, v. 11, no. 1, p. 39-57.

1975, Comparison of textures and structures to distinguish eolian environments, Killpecker dune field, Wyoming: Mtn. Geologist, v. 12, no. 2, p. 61-73.

Anderson, E. N., and Walker, E. R., 1920, An ecological study of the algae of some Sand Hills lakes: Am. Microscop. Soc. Trans., v. 39, p. $51-85$.

Bagnold, R. A., 1941, The physics of blown sand and desert dunes: Methuen \& Co., London, $265 \mathrm{p}$.

Bigarella, J. J.,1975, Lagoa dune field, State of Santa Catarina, Brazil-A model of eolian and pluvial activity, in International symposium on the Quaternary, southern Brazil, July 15-31, 1975: Boletim Paranaense Geociências, no. 33, p. 133-167.

Bradley, Edward, and Rainwater, F. H., 1956, Geology and groundwater resources of the upper Niobrara River basin, Nebraska and Wyoming: U.S. Geol. Survey Water-Supply Paper 1368, $70 \mathrm{p}$.

Brice, J. C., 1964, Channel patterns and terraces of the Loup Rivers in Nebraska: U.S. Geol. Survey Prof. Paper 422-D, 41 p.

Condra, G. E., 1918, Preliminary report on the potash industry of Nebraska: Lincoln, Nebr., Nebraska Conservation and Soil Survey Bull. 8, $39 \mathrm{p}$.

1932, The ground waters and lakes of the Sand Hills region, Nebraska: Nebraska Irrigation Assoc. Proc., p. 42-48.

Folk, R. L., 1968, Petrology of sedimentary rocks: Austin, Tex., Hemphill, $170 \mathrm{p}$.

Folk, R. L., Andrews, P. B., and Lewis, D. W., 1970, Detrital sedimentary rock classification and nomenclature for use in New Zealand: New Zealand Jour. Geology and Geophysics., v. 13, no. 4, p. 937-968.

Frankel, L., 1957a, The value of Pleistocene mollusks as index fossils of Wisconsin sub-ages in Nebraska: Jour. Paleontology, v. 31, no. 3, p. 641-647.

1957b, Nebraska's loess deposits-grassland or woodland environment?: Jour. Paleontology, v. 32, no. 3, p. 638-639.

Fryberger, S. G., 1979, Dune forms and wind regime, in McKee, E. D., ed., A study of global sand seas: U.S. Geol. Survey Prof. Paper 1052, p. 137-169.

Frye, J. C., Willman, H. B., and Glass, H. D., 1968, Correlation of midwestern loesses with the glacial sequence, in Schultz, C. B., and Frye, J. C., eds., Loess and related eolian deposits of the world: Lincoln, Nebr., Nebraska Univ. Press, p. 3-22.
Harms, J. C., MacKenzie, D. B., and McCubbin, D. G., 1963, Stratification in modern sands of the Red River, Louisiana: Jour. Geology, v. 71, no. 5, p. 566-580.

Hicks, W. B., 1921, 'The potash resources of Nebraska: U.S. Geol. Survey Bull. 715-I, p. 125-139.

Hunter, R. E., 1977, Basic types of stratification in small eolian dunes: Sedimentology, v. 24, no. 3, p. 361-387.

Keech, C. F., and Bentall, Ray, 1971, Dunes on the plains-The Sand Hills region of Nebraska: Nebraska Univ., Conserv. and Survey Div. Resource Rept. 4, $18 \mathrm{p}$.

Lugn, A. L., 1935, The Pleistocene geology of Nebraska: Nebraska Geol. Survey Bull. 10, 2nd ser., 223 p.

1960, The origin and sources of loess in the Great Plains in North America: Internat. Geol. Cong., 21st, Copenhagen, 1960, Rept., pt. 21, p. 223-235.

1962, The origin and sources of loess in the central Great Plains and adjoining areas of the central lowland: Nebraska Univ. Studies. new ser., no. 26, Pt. XI, 105 p.

1968, The origin of loesses and their relation to the Great Plains in North America, in Schultz, C. B., and Frye, J. C., eds., Loess and related eolian deposits of the world: Lincoln, Nebr., Nebraska Univ. Press, p. 139-182.

McKee, E. D., 1934, The Coconino Sandstone-Its history and origin: Carnegie Inst. Washington, Pub. 440, p. 77-115.

1957, Primary structures in some recent sediments: Am. Assoc. Petroleum Geologists Bull., v. 41, no. 8, p. 1704-1747.

1966, Structures of dunes at White Sands National Monument, New Mexico (and a comparison with structures of dunes from other selected areas): Sedimentology, v. 7, no. 1, Spec. Issue, p. 3-69.

McKee, E. D., Douglass, J. R., and Rittenhouse, Suzanne, 1971, Deformation of lee-side laminae in eolian dunes: Geol. Soc. America Bull., v. 82, no. 2, p. 359-378.

McKee, E. D., and Moiola, R. J., 1975, Geometry and growth of the White Sands dune field, New Mexico: U.S. Geol. Survey Jour. Research, v. 3, no. 1, p. 59-66.

McKee, E. D., and Tibbetts, G. C., Jr., 1964, Primary structures of a seif dune and associated deposits in Libya: Jour. Sed. Petrology, v. 34, no. 1, p. 5-17.

Melton, F. A., 1940, A tentative classification of sand dunes-Its application to dune history in the southern High Plains: Jour. Geology, v. 48, no. 2, p. 113-174.

Picard, M. D., 1975, Facies, petrography and petroleum potential of Nugget Sandstone (Jurassic), southwestern Wyoming and northeastern Utah, in Bolyard, D. W., ed., Symposium on deep drilling frontiers in the central Rocky Mountains: Denver, Colo. Rocky Mtn. Assoc. Geol., p. 109-128.

Reed, E. C., and Dreeszen, V. H., 1965, Revision of the classification of the Pleistocene deposits of Nebraska: Nebraska Geol. Survey Bull. 23, 65 p.

Reiche, Parry, 1938, An analysis of cross-lamination-the Coconino sandstone: Jour. Geology, v. 46, no. 7, p. 905-932.

Schultz, C. B., and Frye, J. C., eds., 1968, Loess and related eolian deposits of the world: Lincoln, Nebr., Nebraska Univ. Press, $345 \mathrm{p}$.

Sears, P. B., 1961, A pollen profile from the grassland province: Science, v. 134, no. 3495, p. 2038-2039.

Smith, H. T. U:, 1965, Dune morphology and chronology in central and western Nebraska: Jour. Geology, v. 73, no. 4, p. 557-578.

1968, Nebraska dunes compared with those of North Africa and other regions, in Schultz, C. B. and Frye, J. C., eds., Loess and related eolian deposits of the world: Lincoln, Nebr., Nebraska Univ. Press, p. 29-47. 
Stanley, K. O., and Wayne, W. J., 1972, Epeirogenic and climatic controls of early Pleistocene fluvial sediment dispersal in Nebraska: Geol. Soc. America Bull., v. 83, no. 12, p. 3675-3690.

Steen, M. O., 1961, Sand Hill Lake survey: Nebraska Game, Forestation and Parks Commission Rept. for period July 1954 to Dec. $31,1960$.

Swinehart, J. B., 1972, Preliminary results of shallow drilling in the Nebraska Sand Hills: Nebraska Acad. Sci. Proc., no. 82, p. 83.

Till, Roger, 1974, Statistical methods for the earth scientist, an introduction: New York, John Wiley, 154 p.

Tsoar, Haim, 1978, The dynamics of longitudinal dunes: Hebrew University, Ph.D. thesis, 250 p.
Walker, T. R., and Harms, J. C., 1972, Eolian origin of flagstone beds, Lyons Sandstone (Permian), type area, Boulder County, Colorado, in Environments of sandstone, carbonate, and evaporite deposition: Mtn. Geologist, v. 9, no. 2-3, p. 279-288.

Warren, Andrew, 1968, Dune volume and trend measurements in the Nebraska Sand Hills [abs.]: Nebraska Acad. Sci. Proc., v. 78, p. 23.

Watts, W. A., and Wright, H. E., Jr., 1966, Late-Wisconsin pollen and seed analysis from the Nebraska Sand Hills: Ecology, v. 47, no. 2 , p. 202-210.

Wehrman, K. C., 1961, A study of the transition zone between the Loess Hills and Sand Hills in central Nebraska: Nebraska Univ. M. S. thesis. 


\section{Paleoecology of Nonmarine Mollusca from some Paleointerdune Deposits in the Nebraska Sand Hills}

By JOHN H. HANLEY

GEOLOGIC AND PALEOECOLOGIC STUDIES OF THE NEBRASKA SAND HILLS

GEOLOGICAL SURVEY PROFESIONAL PAPER $1120-$ B 


\section{CONTENTS}

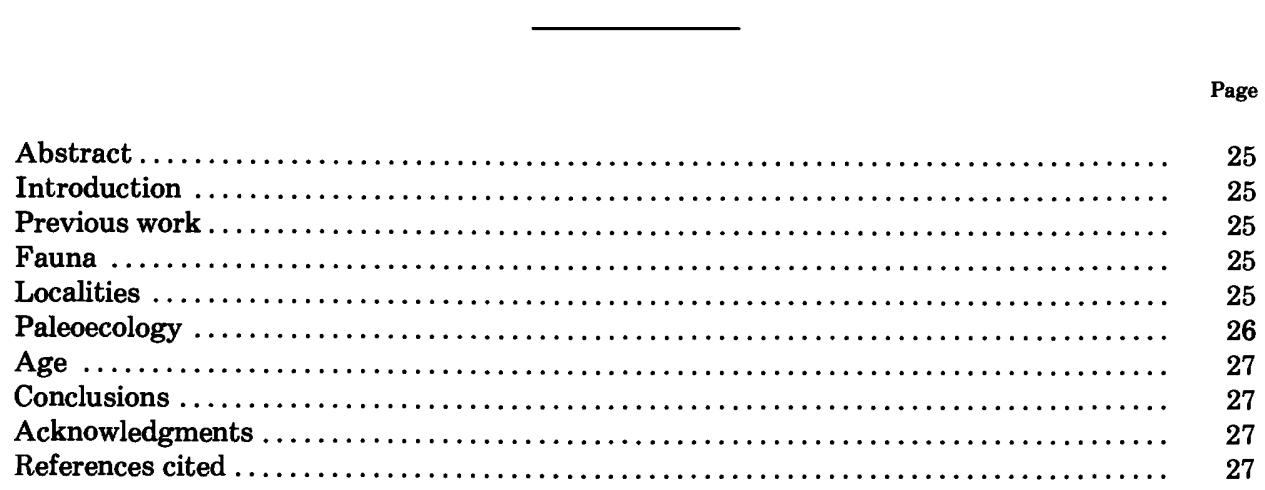

\section{ILLUSTRATIONS}

[Plates follow index]

Plates 1-2. Mollusks from paleointerdune deposits in the Nebraska Sand Hills.

\section{TABLES}

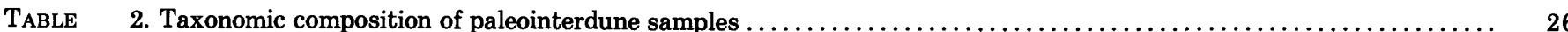
3. Habitat indications of paleointerdune mollusks 


\title{
PALEOECOLOGY OF NONMARINE MOLLUSCA FROM SOME PALEOINTERDUNE DEPOSITS IN THE NEBRASKA SAND HILLS
}

\author{
BY JOHN H. HANLEY
}

\begin{abstract}
Three assemblages of nonmarine Mollusca from paleointerdune deposits in the Nebraska Sand Hills inhabited shallow, quiet, vegetated, subpermanent or temporary, freshwater interdune ponds and adjacent terrestrial habitats. Analysis of factors affecting the taxonomic composition, diversity, and abundance of species in living assemblages of mollusks support this interpretation. The mollusks have long biostratigraphic ranges and broad biogeographic distributions. They fail to establish precise age relations of the faunas other than middle or late Pleistocene to Holocene.
\end{abstract}

\section{INTRODUCTION}

This paper documents the molluscan fauna of some paleointerdune deposits in the Nebraska Sand Hills and interprets their paleoecology. Such documentation is needed to clarify depositional environments within interdune areas that have been inadequately studied and are of potential economic significance (chapter A).

\section{PREVIOUS WORK}

Pleistocene and Holocene mollusks of the Great Plains have been studied extensively. (Taylor, 1975, includes index of genera and species and extensive bibliography.) Although the Quaternary mollusks of Nebraska have been discussed by many authors (Taylor, 1975, p. 14-15, summary), the mollusks of the Nebraska Sand Hills have not been adequately studied. Taylor's summary $(1960$, p. 42-44) of Holocene mollusks from 14 aquatic and terrestrial habitats in the Nebraska Sand Hills and adjacent High Plains, and his discussion (Taylor, 1960, p. 32-36; 1966, p. 95-96) of the Sand Draw local fauna (preNebraskan?) of north-central Nebraska provide im- portant faunal and habitat data for interpretation of paleointerdune mollusks.

\section{FAUNA}

Taxonomy of mollusks reported here has been discussed by many authors, including Herrington and Taylor (1958), Taylor (1960), Hibbard and Taylor (1960), Herrington (1962), Miller (1966), and LaRocque (1968, 1970). The taxonomic composition, rank abundance, and number of specimens of each species in a collection are summarized in table 2 . The fauna is illustrated in plates 1 and 2 (following index).

\section{LOGALITIES}

Following is a summary of locality and lithologic and stratigraphic data for the paleontologic samples from interdune deposits. The distribution of localities in central and north-central Nebraska is shown in figure 1 of chapter $\mathrm{A}$.

USGS Cenozoic locality D1116NM:

$\mathrm{NE}^{1 / 4}, \mathrm{SW}^{1 / 4}$, Sec. 19 , T. 34 N., R. 39 W., Cherry County,

Nebraska; Irwin 15-minute quadrangle. Feldsarenite collected $1.2 \mathrm{~m}$ below surface of ground from second inferred interdune deposit above base in a series of five inferred interdune deposits that are interbedded with dure sand. Locality 2 (sample NS 2) of Ahlbrandt and Fryberger (chapter A). The deposit yielding the fauna is unnamed.

USGS Cenozoic locality D1117NM:

$\mathrm{NE}^{1 / 4}, \mathrm{SW}^{1 / 4}$, Sec. 19, T. 34 N., R. 39 W., Cherry County, Nebraska; Irwin 15-minute quadrangle. Muddy sand feldsarenite collected $0.9 \mathrm{~m}$ below surface of ground from third inferred interdune deposit above base in a series of five inferred interdune deposits that are interbedded with dune sand. Locality 2 (sample NS 3) of Ahlbrandt and Fryberger (chapter A). The deposit yielding the fauna is unnamed and is $0.3 \mathrm{~m}$ stratigraphically above sample D1116NM. 
USGS Cenozoic locality D1119NM:

$\mathrm{SE}^{1 / 4}, \mathrm{NW}^{1 / 4}$, Sec. 10, T. 22 N., R. 35 W., Hooker County, Nebraska; Dismal River 15-minute quadrangle. Claystone collected from inferred interdune deposit which is interbedded with unconsolidated dune sand. Locality 71 (sample NP-7) of Ahlbrandt and Fryberger (chapter A). The deposit yielding the fauna is unnamed.

TABLE 2.-Taxonomic composition of paleointerdune samples. The two numbers given for each species indicate the rank abundance and number of specimens in a collection, respectively

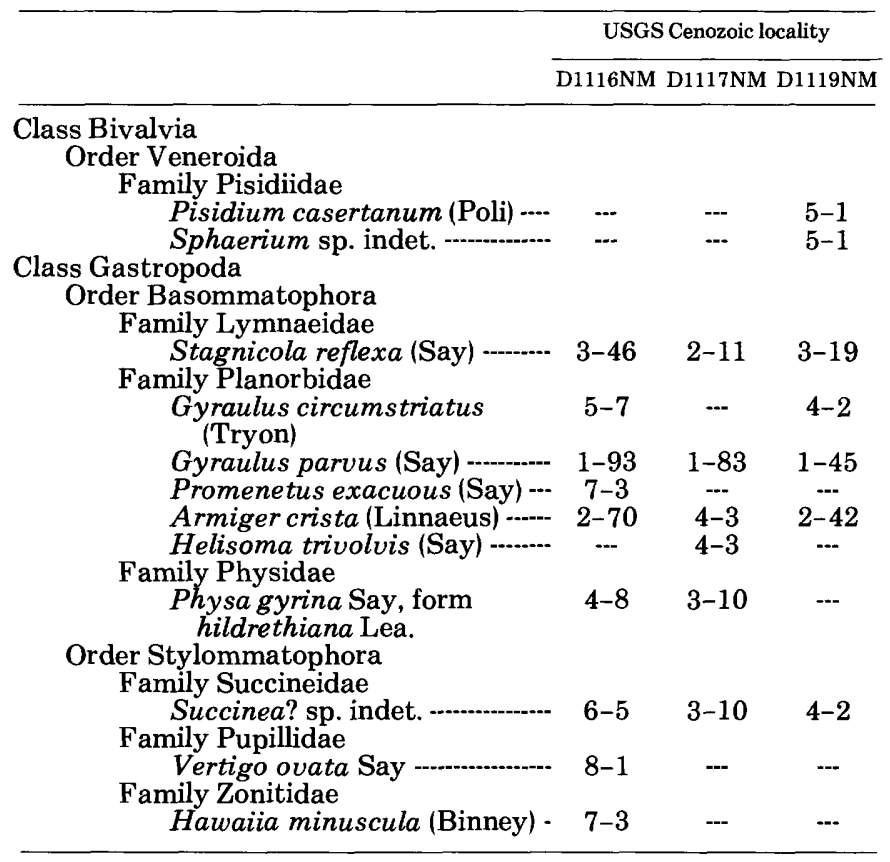

\section{PALEOECOLOGY}

Analysis of factors affecting the taxonomic composition, diversity, and abundance of Mollusca is critical in the interpretation of nonmarine paleoenvironments. Paleoecologic interpretations should be preceded by reconstruction of the pre- and post-burial history (taphonomy) of the fossil assemblage, to determine if the mollusks could have lived in the same habitat and if they were preserved in the environment in which they had lived (that is, whether they represent a biocoenosis or life-association). Taylor $(1960,1965)$ provided an excellent review of principles of paleoecologic interpretation of late Pliocene and Pleistocene nonmarine mollusks.

Although the taphonomy of mollusks in the paleointerdune samples is poorly documented, several factors suggest that reliable paleoecologic interpretations can be made. All taxa in table 2 are extant, have broad biogeographic distributions, and have been reported from Pleistocene and Holocene deposits in Nebraska. The ecologic compatibility of these living species is well documented and suggests that the samples differ from molluscan biocoenoses only in the minor admixture of terrestrial gastropods (Succinea, Vertigo ovata, and Hawaiia minuscula) from adjacent habitats.

The habitat distributions of the mollusks are discussed by many authors, but are concisely summarized by Hibbard and Taylor (1960), Taylor (1960), and LaRocque $(1968,1970)$. Primarily on the basis of Taylor's work (1960), habitat preferences are summarized in table 3 . The mollusks from the three paleointerdune deposits inhabited shallow, quiet, vegetated, subpermanent or temporary freshwater, interdune ponds. The presence of Pisidium casertanum and(or) Armiger crista suggests that the ponds may have been seasonally ephemeral. Vertigo ovata probably lived in moist leaves and humus at the margin of the pond. Hawaiia minuscula, which can withstand arid conditions, also lived adjacent to the pond but in a somewhat drier terrestrial habitat under leaves, logs, or rocks.

Aquatic pulmonate gastropods (Planorbidae, Lymnaeidae, and Physidae), which dominate the collections (rank abundances of taxa, table 2), are excellently adapted for life in local, even ephemeral, aquatic habitats. The mantle cavity, which normally contains the gills, has been modified into a pulmonary sac. The gills are replaced by a plexus of blood vessels in the roof of the pulmonary sac. Oxygen may pass into the sac through a single opening, the pneumostome. Physidae and Lymnaeidae come to the surface and obtain atmospheric oxygen by bringing the pneumostome into contact with the air-water interface. This trait is advantageous in allowing them to tolerate reduced oxygen concentration in their aquatic habitat. Lymnaeid gastropods can also breathe oxygen directly from the water through their skins by a process termed cutaneous respiration. Planorbidae also exhibit a secondary, external gill termed the pseudobranch. These gastropods are able to respire subaqueously using their false gills.

Aquatic pulmonates often exhibit remarkable tolerance to environmental stress, such as desiccation of their aquatic habitat (for example, Helisoma trivolvis). Many are able to reduce their metabolism and aestivate, as do terrestrial pulmonate gastropods. Some pisidiid bivalves (for example, Pisidium casertanum) are also able to withstand desiccation of their habitat by burrowing into moist sediment, often beneath stones. Their ovoviviparity promotes survival of offspring in that the young are released from the parent as fully developed juvenile bivalves.

High-dispersal potential of aquatic pulmonates and pisidiids promotes rapid colonization of local habitats. 
TABLE 3.-Habitat indications of paleointerdune mollusks, and comparison with a portion of the Sand Draw local fauna and Holocene mollusks from northern Nebraska, based on Taylor $(1960$, p. 36)

\begin{tabular}{|c|c|c|c|c|c|c|}
\hline \multirow{3}{*}{ Habitat } & \multirow{3}{*}{ Species } & \multicolumn{5}{|c|}{ Occurrence } \\
\hline & & \multicolumn{3}{|c|}{ USGS Cenozoiclocality } & \multirow[b]{2}{*}{$\begin{array}{l}\text { Sand Draw } \\
\text { local fauna }\end{array}$} & \multirow[b]{2}{*}{ Recent } \\
\hline & & D1116NM & D1117NM & D1119NM & & \\
\hline \multirow{2}{*}{$\begin{array}{l}\text { Permanent to temporary water } \\
\text { Permanent or subpermanent }\end{array}$} & \multirow{7}{*}{ 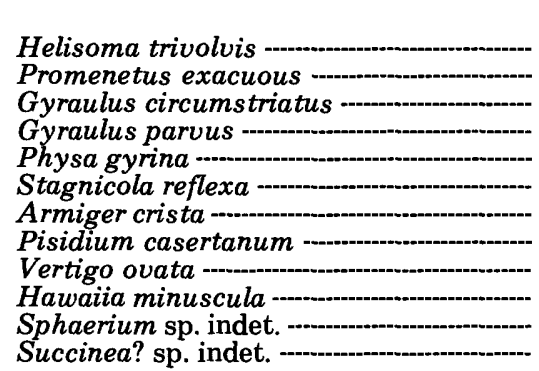 } & \multirow{7}{*}{\begin{tabular}{l}
$\bar{X}$ \\
$\mathrm{X}$ \\
$\mathrm{X}$ \\
$\mathrm{X}$ \\
$\mathrm{X}$ \\
$\mathrm{X}$ \\
\hdashline $\bar{X}$ \\
$\mathrm{X}$ \\
- \\
$\mathrm{X}$
\end{tabular}} & \multirow{7}{*}{\begin{tabular}{l}
$\mathrm{X}$ \\
\hdashline- \\
$\overline{\mathrm{X}}$ \\
$\mathrm{X}$ \\
$\mathrm{X}$ \\
$\mathrm{X}$ \\
$\cdots-$ \\
\hdashline- \\
\hdashline- \\
$\overline{\mathrm{X}}$
\end{tabular}} & \multirow{7}{*}{$\begin{array}{l}\overline{-} \\
\bar{X} \\
\mathrm{X} \\
\overline{\mathrm{X}} \\
\mathrm{X} \\
\mathrm{X} \\
\overline{--} \\
\overline{\mathrm{X}} \\
\mathrm{X}\end{array}$} & \multirow{7}{*}{\begin{tabular}{l}
$\cdots$ \\
$\cdots$ \\
\hdashline- \\
$X$ \\
$X$ \\
$\mathrm{X}^{1}$ \\
\hdashline $\bar{X}$ \\
$\mathrm{X}$ \\
$\mathrm{X}$ \\
$\mathrm{X}$ \\
$\mathrm{X}$
\end{tabular}} & \multirow{7}{*}{$\begin{array}{l}\mathrm{X} \\
\mathrm{X} \\
\mathrm{X} \\
\mathrm{X} \\
\mathrm{X} \\
-\mathrm{X} \\
\mathrm{X} \\
\mathrm{X} \\
\mathrm{X} \\
\mathrm{X} \\
\mathrm{X}\end{array}$} \\
\hline & & & & & & \\
\hline Permanent or temporary & & & & & & \\
\hline Temporary pond or marginal pool & & & & & & \\
\hline Moister humus & & & & & & \\
\hline Damp to dry ground & & & & & & \\
\hline Uncertain ---ar & & & & & & \\
\hline
\end{tabular}

Aquatic pulmonates typically lay their eggs on shallow aquatic vegetation, thereby increasing the chance of aerial dispersal on the legs of water birds (Rees, 1965). Pisidiids are known to be locally dispersed by insects (Fernando, 1954; Rees, 1965). The abundance of aquatic pulmonates in the presumed interdune pond habitat is enhanced by their hermaphroditic reproduction.

\section{AGE}

Table 3 illustrates the similarity between the paleointerdune faunas, a portion of the Sand Draw local fauna, and Holocene mollusks reported from northern Nebraska by Taylor (1960). Helisoma trivolvis, Promenetus exacuous, Gyraulus circumstriatus, and Armiger crista are unknown in deposits as old as the Sand Draw local fauna (preNebraskan?) in North America.

The paleointerdune mollusks are all extant and have long biostratigraphic ranges and broad biogeographic distributions. They are of little utility in determining precise age relations of the paleointerdune deposits, as summarized below:

USGS Cenozoic locality D1116NM: The presence of Promenetus exacuous (equivalent to $P$. exacuous form exacuous of Miller, 1966 , p. 233-235) suggests that this fauna is late Pleistocene (Illinoian) to Holocene in age.

USGS Cenozoic locality D1117NM: Armiger crista is unknown in North America in deposits older than middle Pleistocene (Hibbard and Taylor, 1960). This fauna is middle Pleistocene to Holocene in age.

USGS Cenozoic locality D1119NM: Gyraulus circumstriatus is unknown in deposits older than middle Pleistocene (Kansan) (Hibbard and Taylor, 1960). G. circumstriatus in association with Armiger crista suggests that this fauna is of middle Pleistocene (Kansan) to Holocene age. The deposit yielding this fauna is $\mathrm{C}^{14}$ dated at $500 \pm 200$ years B.P. (before the present) (USGS Sample No. W-185).

\section{GONGLUSIONS}

Three assemblages of nonmarine Mollusca from paleointerdune deposits in the Nebraska Sand Hills inhabited shallow, quiet, vegetated, subpermanent or temporary freshwater interdune ponds and adjacent terrestrial habitats. Ecology and adaptations of living representatives of these species support this interpretation. The mollusks have long biostratigraphic ranges and fail to establish precise age relations of the faunas.

\section{AGKNOWLEDGMENTS}

Thomas S. Ahlbrandt and Bruce R. Wardlaw reviewed the manuscript and offered suggestions for its improvement. Leonard A. Wilson, Robert O'Donnell, and Robert E. Burkholder assisted in photography of mollusks. I am especially grateful to Aurèle LaRocque, Ohio State University, who examined gastropods and provided insight into problems of molluscan taxonomy and paleoecology. However, the responsibility for taxonomy of the mollusks and paleoecologic interpretation rests solely with the author.

\section{REFERENCES CITED}

Fernando, C. H., 1954, The possible dispersal of Pisidium by Corixidae (Hemiptera): Jour. Conch., v. 24, p. 17-19.

Herrington, H. B., 1962, A revision of the Sphaeriidae of North America (Mollusca; Pelecypoda): Michigan Univ. Mus. Zoology Misc. Pub. 118, 74 p.

Herrington, H. B., and Taylor, D. W., 1958, Pliocene and Pleistocene Sphaeriidae (Pelecypoda) from the central United States: Michigan Univ. Mus. Zoology Occasional Paper 596, 28 p.

Hibbard, C. W., and Taylor, D. W., 1960, Two late Pleistocene faunas from southwestern Kansas: Michigan Univ. Mus. Paleontology Contr., v. 16, no. 1, 223 p. 
LaRocque, Aurèle, 1968, Pleistocene Mollusca of Ohio: Ohio Div. Geol. Survey Bull. 62, pt. 3 (of 4 parts), p. 357-553.

1970, Pleistocene Mollusca of Ohio: Ohio Div. Geol. Survey Bull. 62 , pt. 4 (of 4 parts), p. 555-800.

Miller, B. B., 1966, Five Illinoian molluscan faunas from the southern Great Plains: Malacologia, v. 4, no. 1, p. 173-260.

Rees, W. J., 1965, The aerial dispersal of Mollusca: Malacological Soc. London, Proc., v. 36, p. 269-282.

Taylor, D. W., 1960, Late Cenozoic molluscan faunas from the High Plains: U.S. Geol. Survey Prof. Paper 337, 94 p.
1965, The study of Pleistocene nonmarine mollusks in North America, in Wright, H. E., Jr., and Frey, D. G., eds., The Quaternary of the United States: Princeton, N.J., Princeton Univ. Press, p. 597-611.

1966, Summary of North American Blancan nonmarine mollusks: Malacologia v. 4, no. 1, p. 1-172.

1975, Index and bibliography of late Cenozoic freshwater Mollusca of western North America: Michigan Univ. Papers on Paleontology 10, $384 \mathrm{p}$. 


\section{Late Quaternary Vegetation History of the Central Great Plains and its Relationship to Eolian Processes in the Nebraska Sand Hills}

By J. PLATT BRADBURY

GEOLOGIC AND PALEOECOLOGIC STUDIES OF THE NEBRASKA SAND HILLS

GEOLOGICAL SURVEY PROFESSIONAL PAPER $1120-\mathrm{C}$ 


\section{CONTENTS}

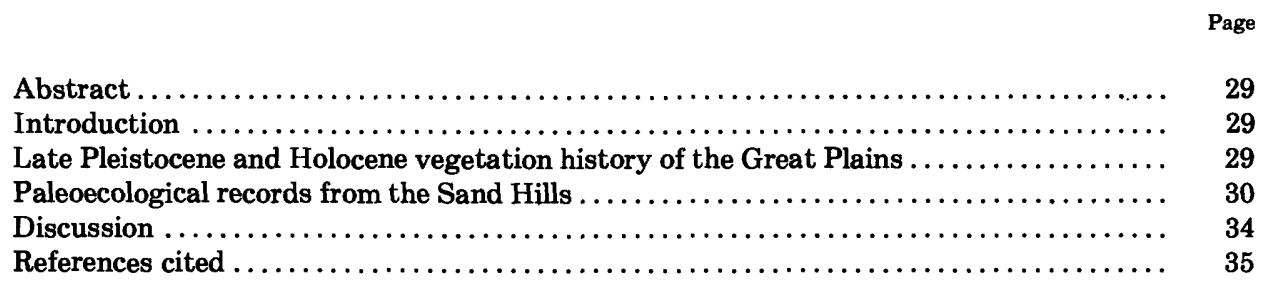

\section{ILLUSTRATIONS}

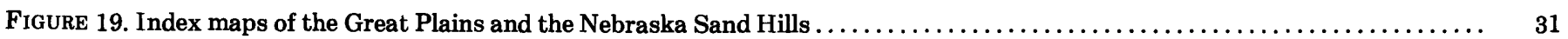

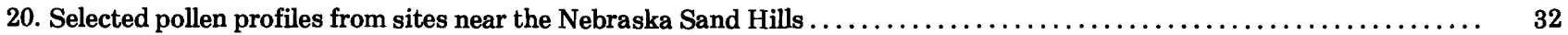

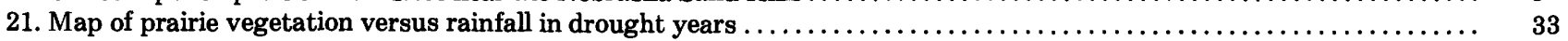

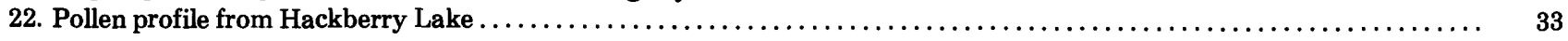

\section{TABLES}

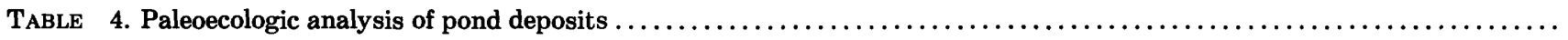




\title{
LATE QUATERNARY VEGETATION HISTORY OF THE GENTRAL GREAT PLAINS AND ITS RELATIONSHIP TO EOLIAN PROCESSES IN THE NEBRASKA SAND HILLS
}

\author{
By J. Platt Bradbury
}

\begin{abstract}
A review of the vegetation history of the Great Plains during the late Pleistocene indicates that boreal coniferous forests containing substantial amounts of spruce (Picea) surrounded the Nebraska Sand Hills. Probably similar vegetation existed in the Sand Hills as well. The eolian mechanisms that produced the present Sand Hills topography could not operate compatibly with forest vegetation, and it is hypothesized that the latest major epoch of sand dune formation occurred after the forests left, in the middle Holocene. Perhaps this eolian activity coincided with the Altithermal, a warm and dry period between 8,000 and 4,000 years B.P. (before the present) that is recorded in pollen records of the eastern Great Plains. $\mathrm{C}^{14}$ dates in the Sand Hills suggest that sand movement and deposition occurred in different areas at different times, and that the dune field has a complex history.
\end{abstract}

\section{INTRODUCTION}

The environmental history of the Nebraska Sand Hills (fig. 19) can be considered from two viewpoints. The first involves the eolian processes that transported and deposited the sand across northern Nebraska, and the second concerns the biological environments that existed during and after the time of dune deposition. To a large extent, the geomorphology, internal structure, thickness and distribution of the eolian deposits provide the most relevant information about the nature of the processes involved in sand deposition. However, information about the absolute timing of such events must come from biological materials synchronously deposited within the dunes that can be radiocarbon dated, or from dated fossil sequences near the dune fields that suggest paleoenvironments appropriate to eolian deposition. Traditionally, pollen sequences from lake sediments and fossil molluscan faunas in loess and pond muds provide biological evidence for paleoecological analysis of these environments, and thus form the basis for dating by correlation. Unfortunately, Pleistocene and Holocene environments are not well studied in the Sand Hills or in the areas immediately surrounding them, and ecological inferences and correlations suffer because of the great distances that separate the Sand Hills from better known regions in the eastern and southern portions of the Great Plains. A compounding problem is that the paleoecological records, especially for pollen, are mostly restricted to late Wisconsin and Holocene times, whereas the Sand Hills dune deposits perhaps extend to the early Wisconsin (Smith, 1965), or medial Wisconsin (Reed and Dreeszen, 1965). A brief review of relevant late Wisconsin and Holocene paleoecology will, nevertheless, provide a framework in which Sand Hills paleoenvironments can be studied.

The paleoecological discussion deals with eight sites within the Sand Hills-Rosebud, Swan Lake, Hackberry Lake, the North Loup River peat deposits, and four pond deposits associated with sand dunes or alluvium in Hooker, Cherry, and Thomas Counties, Nebraska (fig. 19). A regional vegetation history is derived from pollen sites in South Dakota, Minnesota, Iowa, Kansas, Missouri, Nebraska, and Texas.

\section{LATE PLEISTOCENE AND HOLOCENE VEGETATION HISTORY OF THE GREAT PLAINS}

Late Pleistocene vegetation records derived from pollen analysis of lake and bog sediments in the central Great Plains (fig. 19) indicate that at the close of the Wisconsin glacial maximum (about 12,000 years ago) boreal forests covered much of the area. The sediment records contain as much as 80 percent spruce (Picea) 
pollen (fig. 20) and, because most authorities acknowledge that only very small quantities of spruce pollen are subject to long distance transport, closed spruce forests are thought to have occurred during this time in southern Minnesota (Jelgersma, 1962; Waddington, 1969), southern South Dakota (Watts and Bright, 1968; Watts and Wright, 1966), northeastern Kansas (Gruger, 1973), west-central Missouri (King and Lindsay, 1976), and northwestern Iowa (Van Zant, 1976). Even values of 10-15 percent spruce pollen, which occur in the late Wisconsin pollen records at Vigo Park of the Llano Estacado, Texas (fig. 19), reflect a substantial colonization of spruce in the immediate area (Oldfield and Schoenwetter, 1975).

With the close of the Pleistocene, the spruce forests retreated northward. They disappeared from Kansas (Gruger, 1973), and, presumably, also from Missouri (King and Lindsay, 1976), about 12,000 years ago, and left South Dakota and southern Minnesota about 10,000 years ago (Jelgersma, 1962; Watts and Bright, 1968; Waddington, 1969). To the east (Kansas, Minnesota, and Iowa), the boreal forests were replaced by deciduous forests (Gruger, 1973; Jelgersma, 1962; Van Zant, 1976), while on the Llano Estacado, pine forests persisted after spruce disappeared (Oldfield and Schoenwetter, 1975). The boreal spruce forest of Manitoba, near the northern edge of the Great Plains was replaced about 9,500 years ago directly by prairie vegetation (Wright, 1970).

The warming trend that was responsible for the deterioration of the boreal forests and their replacement by thermophilous forests of deciduous trees and pine continued into the early Holocene. Between 8,000 and 4,000 years ago prairie vegetation expanded eastward into southern Minnesota and Iowa (Wright, 1968; Van Zant, 1976). A shrunken remnant of this expansion exists today-the so-called Prairie Peninsula-(fig. 21), which corresponds geographically with the position of a mass of dry western air that lies between areas of heavy winter precipitation to the northeast and to the southeast. When this air is not displaced during the summer by moist Gulf of Mexico air masses moving northward, drought conditions follow, and summer precipitation deficiencies increase to the west (fig. 21) (Wright, 1968). The eastward expansion of prairie vegetation 8,000 to 4,000 years ago-the middle Holocene xeric interval-climaxed about 7,000 years ago, and it probably correlates with an increase in the number and intensity of summer droughts (Wright, 1968). Establishment of modern vegetation in the Great Plains began about 4,000 years ago.

\section{PALEOECOLOGICAL RECORDS FROM THE SAND HILLS}

Rosebud is the only site within the Sand Hills that provides a pollen record of late Pleistocene vegetation. The Rosebud site is near the northern edge of the Sand Hills on the Nebraska-South Dakota border at about $101^{\circ} \mathrm{W}$. longitude (fig. 19). The pollen and plant macrofossil records from this site indicate that a boreal spruce forest existed at that location about 12,600 years ago, and that soon after that time a pine forest and then prairie vegetation rapidly replaced the spruce (Watts and Wright, 1966, fig. 20). Seeds and leaves of aquatic macrophytes at the Rosebud site suggest that a fresh, open-water basin existed when spruce was prevalent, and that conditions changed to a species-poor, alkaline reed swamp with the change to prairie vegetation. This vegetation and limnologic history implies a change from cooler, probably somewhat moister climates to one of increased aridity and higher temperatures that characterizes the Sand Hills today. The pollen record of prairie vegetation at Rosebud does not significantly differ from that of modern surface samples in this area (Watts and Wright, 1966).

Subsequent vegetation history at Rosebud is difficult to interpret because the upper sediments lack pollen and do not provide a continuous record. The rapid disappearance of spruce pollen and its immediate replacement by pollen of pine and prairie herbs (fig. 20) suggest a depositional hiatus, although apparently no other stratigraphic or chronologic evidence supports this. All that is clear is that prairie vegetation existed sometime after 12,600 years ago, and that the lake subsequently dried up and either the upper pollenbearing sediments were destroyed, or intermittent fluvial deposition with poor pollen preservation occurred.

FIGURE 19 (facing page).-Index maps of the north-central Great Plains $(A)$ and the Nebraska Sand Hills (shaded, $B$ ). Site localities (A): Pi, Pickerel Lake; Ma, Madelia; Rb, Rosebud; WO, West Lake Okoboji; Mus, Muskotah; BS, Boney Spring; and VP, Vigo Park. Localities in the Nebraska Sand Hills include deposits (NP-4, NP-7, NS-2, and NS-3), pollen sites (Hackberry Lake and Rosebud), and organic deposits (Swan Lake and North Loup River peat deposit). The pond deposits correspond to the following study localities of Ahlbrandt and Fryberger, chapter A, fig. 1: NS-2, loc. 2; NS-3, loc. 3, NP-4, loc. 32; and NP-7, loc. F1. The figures on the Nebraska Sand Hills sites indicate the radiocarbon age, in years, at the base of the deposit. $A$ is modified from Wright (1970), and $B$ from Keech and Bentall (1971). 
VEGETATION HISTORY AND ITS RELATIONSHIP TO EOLIAN PROCESSES
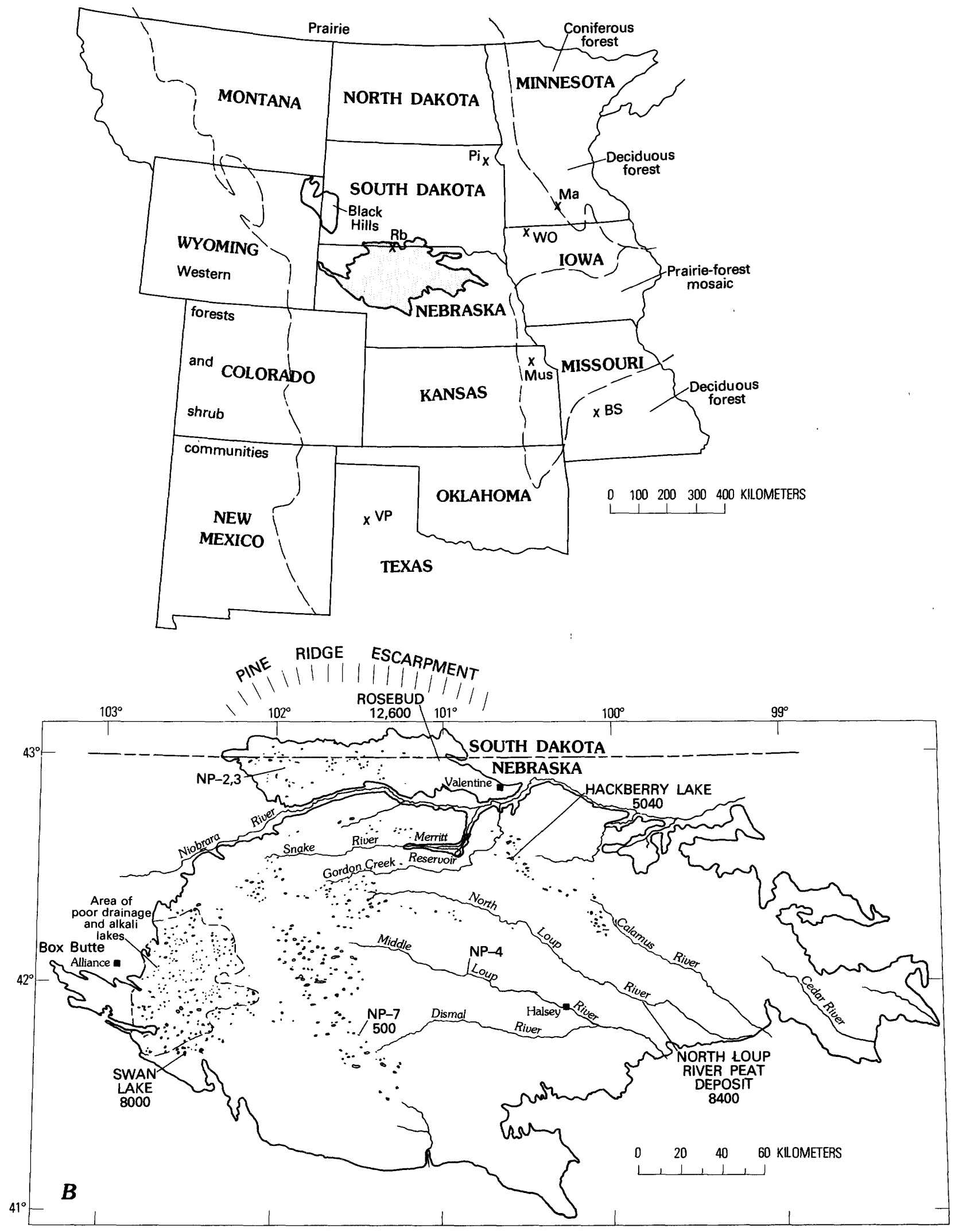


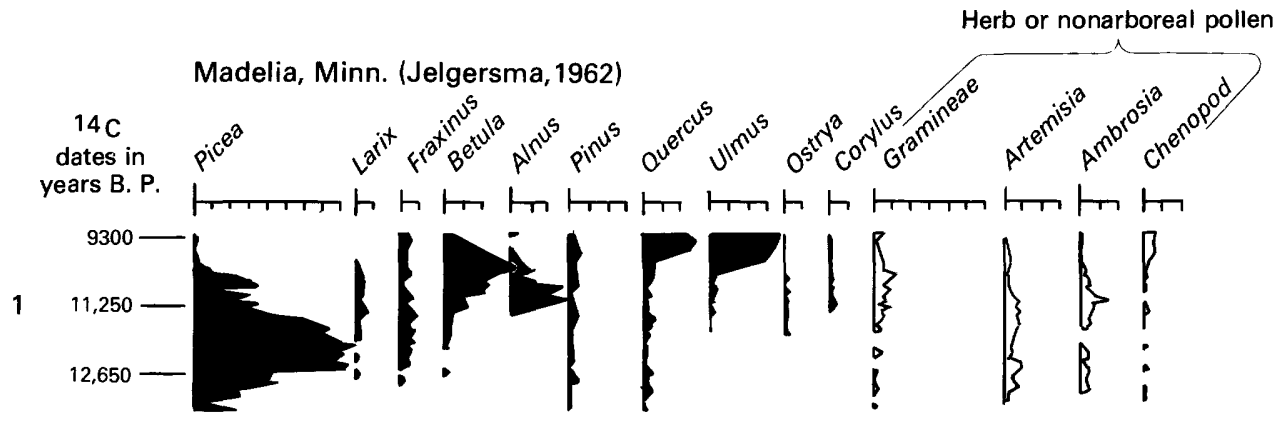

Pickerel, S. Dak. (Watts and Bright, 1968)

2

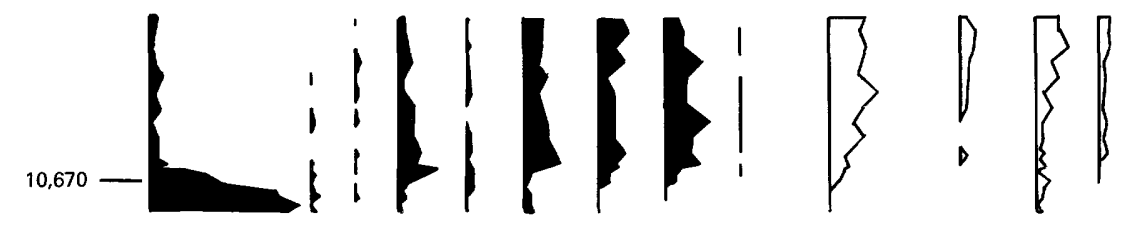

Rosebud, S. Dak. (Watts and Wright, 1966)

3

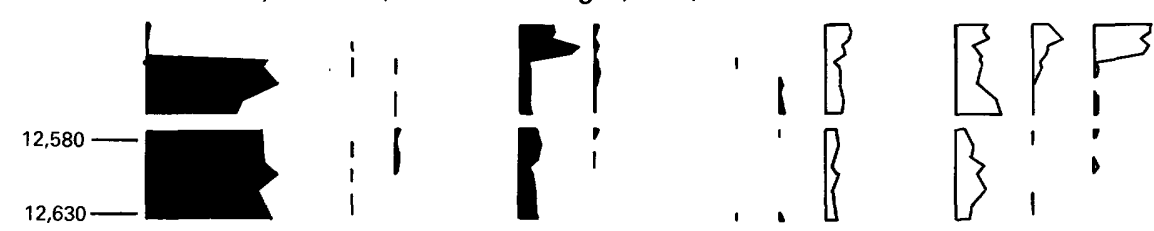

4

Muskotah, Kans. (Grüger, 1973)

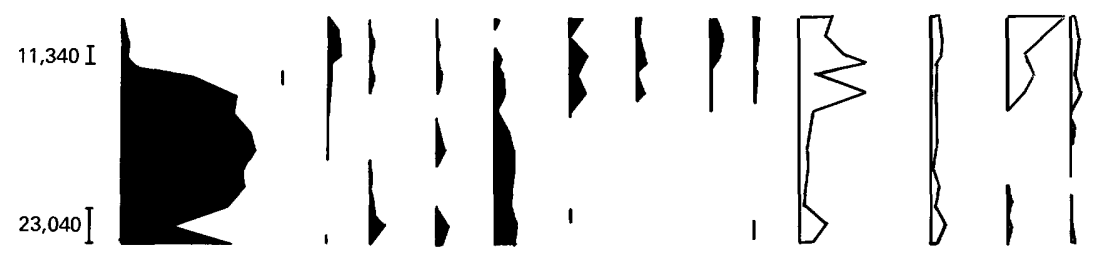

5

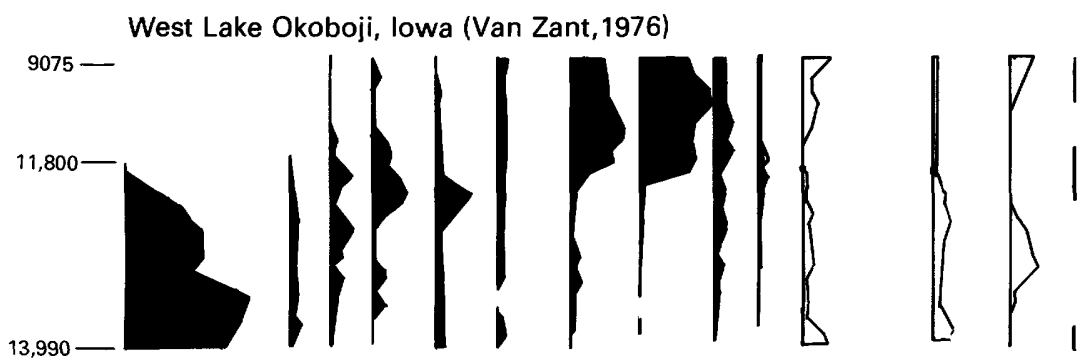

Boney Spring, Mo. (Mehringer and others, 1968)

6

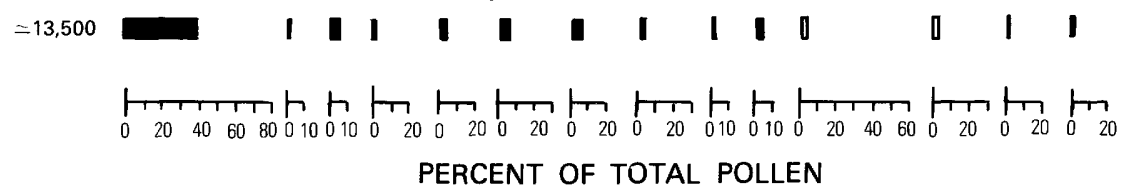

FIGURE 20.-Selected pollen profiles from sites near the Nebraska Sand Hills. 1-4, 6 modified from Wright (1970); 5, modified from Van Zant (1976). 


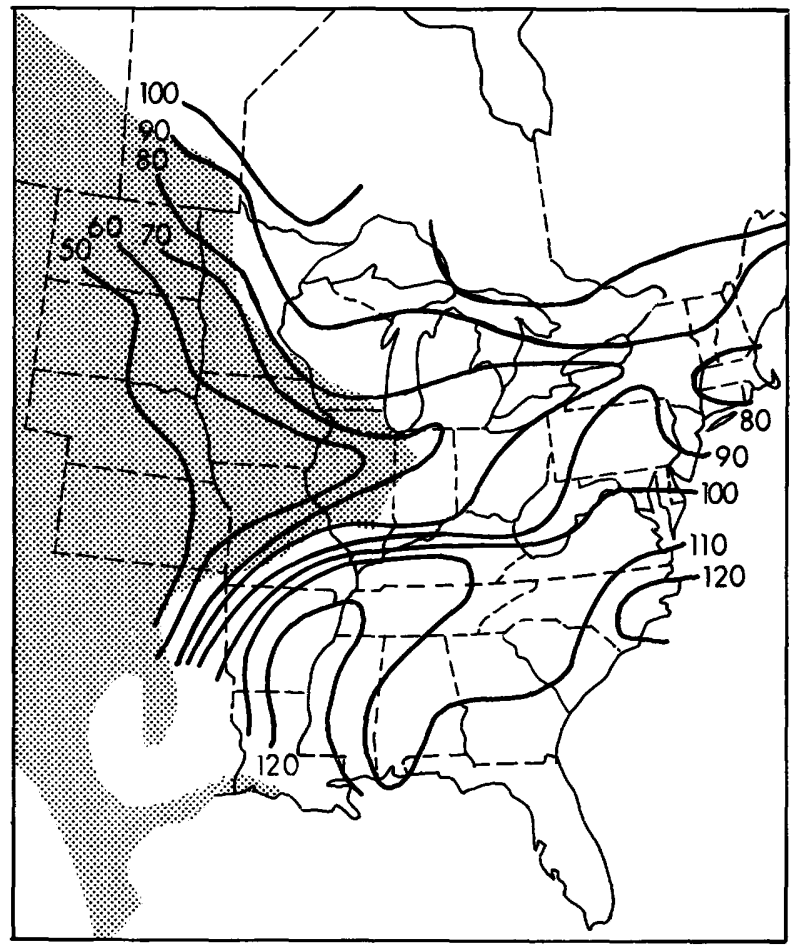

Figure 21.-Extent of prairie vegetation (the so-called Prairie Peninsula, stippled) compared to percent of normal rainfall in average July of major drought years. Modified from Wright (1968).

Another source of paleoenvironmental information comes from peat beds and logs, radiocarbon dated from $10,500 \pm 250$ to $8,400 \pm 250$ years B.P. (before the present), in valley fill associated with the North Loup River (fig. 19). The peat is buried by alluvium which is mantled by dune sand (Brice, 1964). The stratigraphic association of these deposits and the presence of marsh plants like Equisetum (horsetails) indicate that, locally, fluvial processes and riparian environments, similar to those that exist today, were followed by sand movement.

On the southwestern margin of the Sand Hills at Swan Lake (fig. 19), H. E. Wright has taken a core that has a basal radiocarbon date of about 8,000 years B.P. Sedimentation in Swan Lake appears to be continuous to the present, and preliminary pollen analyses indicate a prairie vegetation with minor fluctuations of herbs and grasses throughout this time (H. E. Wright, written commun., 1975).

A subsequent paleoecological record comes from Sears' (1961) pollen diagram from Hackberry Lake in the north-central part of the Sand Hills (fig. 19 and 22). A radiocarbon date indicates that organic deposition began at this site about 5,040 years ago, and the sediments also record a fluctuating dominance of prairie vegetation that persists to the present. The sand dunes that enclose the Hackberry Lake basin are well-preserved barchan and barchanoid-ridge dunes (chapter A) that indicate prevailing wind directions to the southeast.

Among the most recent paleoecological records in the Sand Hills are buried interdune organic deposits no longer associated with current interdune basins. A sample from one such deposit (NP-7, fig. 19, this chapter) yields a radiocarbon date of $500 \pm 200$ years, and testifies to comparatively recent hydrologic and(or) climatic changes in the Sand Hills.

The pollen, diatom, and ostracod assemblages of these deposits (table 4) all contain extant species, and

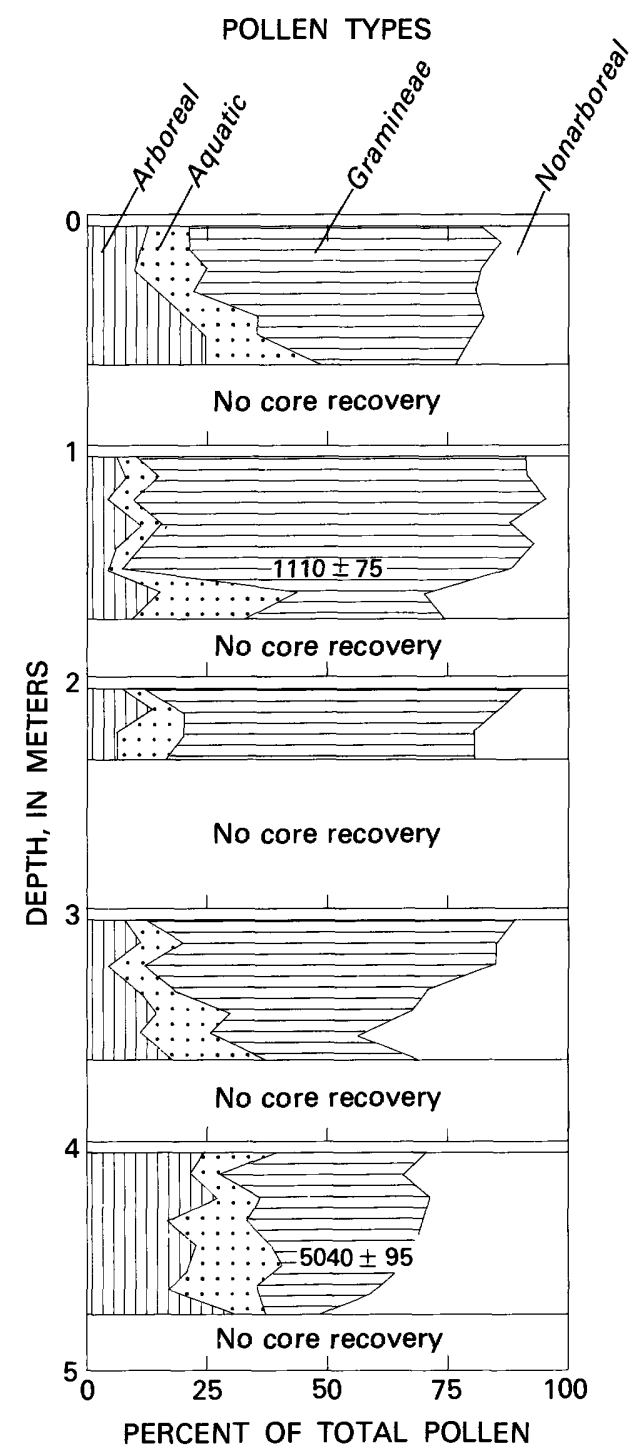

Figure 22.-Pollen profile from Hackberry Lake, near Valentine, Nebraska. Modified from Sears (1961). Numbers in profile represent $\mathrm{C}^{14}$ ages of sediments in years B.P. 
do not provide a firm date for the interdune and fluvial deposits. The pollen data suggest an arid to semiarid climate, but the poor preservation of the pollen grains demands caution in interpreting the pollen assemblage in terms of paleoclimate. Nevertheless, pollen from sample NP-7 (500 \pm 200 years B.P.) strongly resembles the prairie vegetation of assemblage zone $R-2$ of the Rosebud site (Watts and Wright, 1966). All the samples compare closely to collections of modern surface pollen near the Rosebud site (Watts and Wright, 1966). Although sample NS-2 has a high Pinus frequency (50 percent, excluding Cyperaceae), the very poor preservation of pollen in this sample suggests that this frequency might be the result of differential destruction of the more delicate pollen types.

The diatom flora of samples NP-7, NS-2, and NS-3 are moderately well preserved. The diatoms of sample NP-4 are badly broken and corroded. All the samples contain diatoms indicative of shallow, alkaline, and sometimes rather saline water-an environment that characterizes the upper part of the Rosebud core (Watts and Wright, 1966). NS-2 and NS-3 contain forms that suggest fresher and deeper water (for example, Melosira italica, and Fragilaria vaucheriae), but this may be the result of local hydrologic differences rather than climatic (temporal) differences. The admixture of brackish-water and freshwater diatoms suggests that the ponds underwent seasonal changes in salinity.

NP-4 is from pond sediments associated with alluvium stratigraphically beneath the eolian dune deposits. The dominance of Denticula elegans in this sample indicates warm, slightly shallow, brackish water (specific inductance of modern analogs ranges from 1100 to more than 4000). Although the stratigraphic context of the calcareous, diatombearing nodules from NP-4 has not been studied in detail, this diatom association would imply that arid environments existed during some of the time when fluvial processes were active in the Sand Hills region.

The ostracod fauna of NP-7, NS-2, and NS-3 has been identified, and ecological determinations indicate an environment of shallow, alkaline, freshwater ponds, with salinities generally under $3 \%$. Brackish-water species of the genus Limnocythere are not present, possibly suggesting that saline water did not persist in the ponds long enough for an appropriate ostracod fauna to establish itself.
TABLE 4.-Paleoecologic analysis of pond deposits associated with interdune and fluvial sediments in the Nebraska Sand Hills

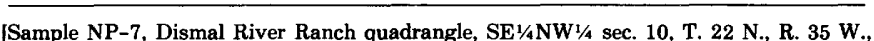
Hooker County. USGS Paleobotany No. D5439. Samples NS-2 and NS-3, Irwin quadrangle, SW1/4 sec. 19, T. 34 N., R. 40 W., Cherry County. NS-2 is approximately $30 \mathrm{~cm}$ below NS-3. USGS Paleobotany No. D5440A and D5440B. Sample NP-4, Seneca quadrangle, NE $1 / 4 \mathrm{NE}^{1 / 4} / 4$ sec. 20, T. 24 N., R. 30 W., Thomas County. USGS Paleobotany No. D5441]

\begin{tabular}{|c|c|c|c|c|}
\hline Sample numbers & NP-7 & NS-2 & NS-3 & $\mathrm{NP}-4$ \\
\hline Pollen types & \multicolumn{4}{|c|}{ Percent total pollen } \\
\hline 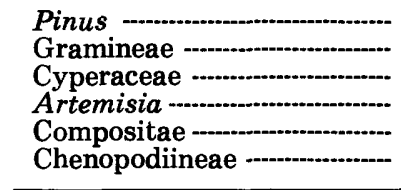 & $\begin{array}{l}16(20)^{1} \\
14(17)^{1} \\
18 \\
3(3.3)^{1} \\
19(23)^{1} \\
26(32)^{1}\end{array}$ & $\begin{array}{l}42(50)^{1} \\
6(7)^{1} \\
16 \\
18(21)^{1} \\
18(21)^{1}\end{array}$ & $\begin{array}{c}\text { Trace... } \\
\text { Trace... } \\
\text {-.- } \\
-- \\
\cdots \\
\cdots\end{array}$ & $\begin{array}{c}\text { Barren } \\
\cdots \\
\cdots \\
\cdots \\
\cdots \\
\cdots\end{array}$ \\
\hline Diatom dominants & \multicolumn{4}{|c|}{ Percent total diatoms } \\
\hline $\begin{array}{l}\text { Amphora ovalis v. lybica -..- } \\
\text { Anomoeoneis costata? } \\
\text { Cocconeis placentula } \\
\text { Denticula elegans }\end{array}$ & $\begin{array}{l}3.4 \\
7.6 \\
2.1 \\
4.7\end{array}$ & $\begin{array}{r}19.3 \\
6.4 \\
-\cdots \\
--.\end{array}$ & $\begin{array}{l}4.0 \\
3.2 \\
5.8 \\
4.4\end{array}$ & $\begin{array}{c}\cdots \\
\cdots \\
77.5\end{array}$ \\
\hline $\begin{array}{l}\text { Fragilaria vaucheriae - } \\
\text { Gomphonema lanceolatum - } \\
\text { Gomphonema spp. } \\
\text { Hantzschia amphioxys }\end{array}$ & $\begin{array}{r}\overline{1.3} \\
2.9 \\
10.2\end{array}$ & $\begin{array}{r}11.6 \\
5.4 \\
10.2 \\
1.9\end{array}$ & $\begin{array}{r}30.1 \\
2.0 \\
1.0 \\
1.6\end{array}$ & $\begin{array}{l}-- \\
\cdots \\
\cdots \\
--\end{array}$ \\
\hline $\begin{array}{l}\text { Melosira italica }-\ldots \\
\text { Nitzschia amphibia } \\
\text { Nitzschia frustulum } \\
\text { Rhopalodia gibba } 2\end{array}$ & $\begin{array}{r}2.1 \\
20.3 \\
13.6 \\
1.3\end{array}$ & $\begin{array}{r}16.0 \\
7.7 \\
1.7 \\
0.7\end{array}$ & $\begin{array}{r}0.2 \\
12.0 \\
4.3 \\
5.0\end{array}$ & $\begin{array}{l}\cdots . \\
5.6 \\
\cdots .4\end{array}$ \\
\hline Ostracods & \multicolumn{4}{|c|}{ Presence (X) } \\
\hline $\begin{array}{l}\text { Cypridopsis vidua } \\
\text { Candona rawsoni } \\
\text { Cyclocypris ampla } \\
\text { Potamocypris sp. } \\
\text { Potamocypris smaradina }\end{array}$ & $\begin{array}{l}\ddot{\mathbf{X}} \\
\mathbf{X} \\
- \\
--\end{array}$ & $\begin{array}{l}\mathbf{X} \\
\mathbf{X} \\
\mathbf{X} \\
\mathbf{X} \\
--\end{array}$ & $\begin{array}{l}\mathbf{X} \\
\mathbf{X} \\
-- \\
-- \\
\mathbf{X}\end{array}$ & $\begin{array}{c}\text { Barren } \\
-- \\
- \\
- \\
-\end{array}$ \\
\hline
\end{tabular}

${ }^{1}$ Percent calculated excluding Cyperaceae.

\section{DISCUSSION}

Ahlbrandt and Fryberger (chapter A) indicate that the dune forms in the main body of the Sand Hills (south of the Niobrara River) were deposited by winds blowing to the southeast. This wind direction can account for all the common dune types, and thus they envision deposition occurring within a single paleoclimatic regime, probably during one continuous period of time.

Although additional paleoecological data is certainly needed, the present information on vegetation history appears to place several constraints on the time of eolian deposition, the source of sand for the presently existing dunes, and the locations in which deposition occurred. 
The Rosebud site, with spruce pollen and macrofossils in levels dated at 12,600 years B.P., must postdate an epoch of sand-dune formation, because the depositional basin containing the pollen record is formed by sand dunes now considerably modified by deflation (chapter A). A boreal spruce forest environment is not consistent with the deposition of barchan and barchanoid-ridge sand dunes. It is likely that the dunes enclosing the Rosebud site predate the Wisconsin maximum (about 18,000 years B.P.) because of evidence of boreal forests during the Wisconsin maximum completely surrounding the Sand Hills; and it seems probable that similar vegetation existed at that time in much of the rest of Nebraska as well.

The North Loup River peat deposits that existed between 10,500 and 8,400 years ago were probably local environments in both time and space which might not preclude approximately contemporaneous environments of eolian deposition. At a minimum these deposits tell us that some sand deposition occurred after 8,400 years ago. On the other hand, the apparently continuous 8,000-year lacustrine record from Swan Lake indicates that, at least locally, hydrologic conditions were stable and that this lake basin was not engulfed by moving sand dunes. These deposits, plus the 5,000-year limnologic history at Hackberry Lake and the intermittent records of lakes and ponds represented by buried interdune organic sediments, suggest that aquatic environments in the Sand Hills have variable histories. They persist for longer or shorter periods of time, and they are both preceded by and followed by periods of sand deposition. A major episode of eolian deposition that simultaneously affected the entire Sand Hills region seems quite unlikely for the past 12,000 years, and perhaps for the past 24,000 years.

The location of the Rosebud site also places a geographic constraint on sand sources. If a distant sand source is required, it must have been to the northwest to conform with the paleowind directions (chapter A). Several authors have suggested Miocene Ogallala Formation or the Pleistocene alluvium as sand sources (chapter A). However, it would seem difficult to transport the sand from northwest to southeast across the Rosebud site (and the Niobrara River) after 12,000 years B.P. without burying these depressions, and no stratigraphic evidence indicates that this occurred. Burial and subsequent exhumation would seem unlikely. Pleistocene dunes such as those that enclose the Rosebud site would likely have existed south of the
Niobrara River, but fluvial activity accompanied by soil and forest development during the late Wisconsin and early Holocene could have destroyed most of the older dune forms and their internal structure. Much of the current eolian topography of the Sand Hills may have been established in the middle Holocene, during the xeric interval $(8,000-4,000$ B.P.) that was synchronous with the maximum expansion of prairie vegetation in southern Minnesota and Iowa. During such times, intensification of summer droughts as predicted by Wright (1968) could have reduced the dune-stabilizing prairie vegetation to such a point that northwesterly winds could rework deposits of preexisting eolian and fluvial sand. Some sand may have been added from the Niobrara River itself, if it were reduced to an intermittent stream at this time. This eolian activity, however, did not encompass the entire Sand Hills region. The Rosebud site persisted throughout the Holocene, although stratigraphic evidence suggests desiccation during some of this time. Perhaps the dunes enclosing Rosebud were partially reworked and modified by blowouts while active sand transport occurred south of the Niobrara River. Ground water moving from the Pine Ridge Escarpment toward the Niobrara River may have aided in the stabilization of the Rosebud dunes and others north of the Niobrara. In a similar sense, the dunes near Swan Lake may have been spared complete reorganization during the middle Holocene xeric interval because they occupy an area of closed drainage (fig. 19) where surface water accumulates and promotes stabilization. Sand dunes generally stabilize first at the upwind margins, and both Rosebud and Swan Lake are in appropriate locations for early sand-dune stabilization. In the central portion of the Sand Hills south of the Niobrara River, dunes reach the greatest thickness (chapter A), and this area probably witnessed the most intense eolian activity during the middle Holocene.

Additional cores and paleoecological studies in the Sand Hills will be necessary to test these assumptions and will likely provide important information about Pleistocene and Holocene climatic changes in the Great Plains.

\section{REFERENCES CITED}

Brice, J. C., 1964, Channel patterns and terraces of the Loup Rivers in Nebraska: U.S. Geol. Survey Prof. Paper 422-D, 41 p.

Griiger, J., 1973, Studies on the late Quaternary vegetation history of northeastern Kansas: Geol. Soc. America Bull., v. 84, no. 1, p. 239-250. 
Jelgersma, S., 1962, A late-glacial pollen diagram from Madelia, south-central Minnesota: Am. Jour. Sci., v. 260, no.7, p. $522-529$.

Keech, C. F., and Bentall, R., 1971, Dunes on the plains; the Sand Hills region of Nebraska: Lincoln, Nebr., Nebraska Univ. Conservation and Survey Division, Resource Rept. 4, 18 p.

King, J. E., and Lindsay, E. H., 1976, Late Quaternary biotic records from spring deposits in western Missouri, in Prehistoric man and his envionments, a case study in the Ozark Highland: New York, Academic Press, p. 63-78.

Mehringer, P. J., Jr., Schweger, C. E., Wood, W. R., and McMillan, R. B., 1968, Late-Pleistocene boreal forest in the Ozark Highlands?: Ecology, v. 49, no. 3, p. 567-568.

Oldfield, F., and Schoenwetter, J., 1975, Discussion of the pollen analytical evidence: in Wendorf, F., and Hester, J. J., eds., Late Pleistocene environments of the southern High Plains: N. Mex., Ranchos de Taos, Fort Burgwin Research Center Pub. 9, 290 p.

Reed, E. C., and Dreeszen, V. H., 1965, Revision of the classifica- tion of the Pleistocene deposits of Nebraska: Nebraska Geol. Survey Bull. 23, 65 p.

Sears, P. B., 1961, A pollen profile from the grassland province: Science, v. 134, no. 3495, p. 2038-2039.

Smith, H. T. U., 1965, Dune morphology and chronology in central and western Nebraska: Jour. Geology, v. 73, no. 4, p. 557-578.

Van Zant, Kent, 1976, Late- and post-glacial vegetational history of northern Iowa: Iowa Univ., Ph.D. Thesis, $197 \mathrm{p}$.

Waddington, J. C. B., 1969, A stratigraphic record of the pollen influx to a lake in the Big Woods of Minnesota in Schumm, S. A., and Bradley, W. C., eds., United States contributions tc Quaternary research: Geol. Soc. America Spec. Paper 123, p. 263-282.

Watts, W. A., and Bright, R. C., 1968, Pollen, seed, and mollusk analysis of a sediment core from Pickerel Lake, northeastern South Dakota: Geol. Soc. America Bull., v. 79, no. 7, p. 855-876.

Watts, W. A., and Wright, H. E., 1966, Late-Wisconsin pollen and seed analysis from the Nebraska Sand Hills: Ecology, v. 47, no. 2, p. 202-210. 


\section{INDEX}

\begin{tabular}{|c|c|}
\hline Abstract $\ldots \ldots \ldots \ldots \ldots \ldots \ldots \ldots \ldots$ & \\
\hline Accretion deposits ... & 8,9 \\
\hline acuta, Candona ........... & 34 \\
\hline Ainsworth, wind regime..... & 7 \\
\hline Algae, nonmarine $\ldots \ldots \ldots \ldots$ & 17 \\
\hline Alliance, wind regime $\ldots \ldots \ldots \ldots$ & 7 \\
\hline Alluvial fans $\ldots \ldots \ldots \ldots$. & 19 \\
\hline amphibia, Nitzschia $\ldots \ldots \ldots \ldots \ldots \ldots \ldots$ & 34 \\
\hline amphioxys, Hantzschia .................. & 34 \\
\hline Amphora ovalis lybica $\ldots \ldots \ldots \ldots \ldots \ldots . . . . .$. & 34 \\
\hline Anomoeoneis costata $\ldots \ldots \ldots \ldots \ldots \ldots \ldots$ & 34 \\
\hline Aquatic macrophytes $\ldots \ldots \ldots \ldots \ldots \ldots \ldots$ & 30 \\
\hline Aquatic pulmonate gastropods $\ldots \ldots \ldots \ldots$ & 26 \\
\hline Armiger crista $\ldots \ldots \ldots \ldots \ldots \ldots \ldots \ldots \ldots \ldots, 26$, & pl. 2 \\
\hline n................... & \\
\hline Artemisia $\ldots \ldots \ldots \ldots \ldots \ldots \ldots \ldots \ldots \ldots \ldots \ldots \ldots \ldots \ldots \ldots \ldots$ & \\
\hline
\end{tabular}

Barchan dunes $\ldots \ldots \ldots \ldots \ldots \ldots \ldots, 5,6,7,33,35$ dip

slipface deposits

Barchanoid-ridge dunes . slipface deposits $\ldots \ldots \ldots \ldots \ldots \ldots \ldots \ldots, \quad 9$

Bedding, contorted . convoluted

Bibliography

Bignell dunesand

Bignell Formation

Bignell Loess

Bioturbation

Bison bones

bison (Linnaeus), Bison (Bison)

Blowout dunes .

cross-bed sets

depth

......................

wind er wind erosion

Boreal forests

Brazil, dissipation structures .............. 29, 30

Burrou

22

C

C

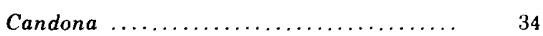
acuta .......................... 34 lactea........................... 34 patzcuaro...................... 34 casertanum, Pisidium ............. 26, 27; pl. 2 Chenopodiineae ...................... 34

Cherry County ..................... 8, 29 alkaline interdune deposits .......... 15

Chert ............................. 21

circumstriatus, Gyraulus ............ 26, 27; pl. 1

Clay .......................... 13, 19, 21

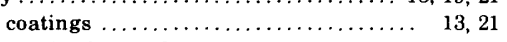
Cocconeis placentula .................. 34

Compositae ......................... 34

Compound dunes ..................... 3

costata, Anomoeoneis .................. 34

crista, Armiger .................... 26, 27; pl 2

Crude oils .......................... 17

Custer County $\ldots \ldots \ldots \ldots \ldots \ldots \ldots \ldots \ldots, 3,21,22$

Cyperaceae.

Cypridopsis vidua
D

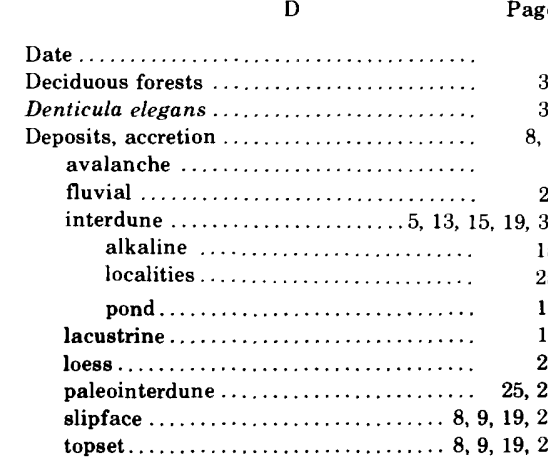

Desiccation cracks ........................... 13

Development........................ 1

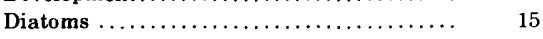

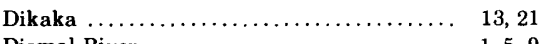

Dismal River $\ldots \ldots \ldots \ldots \ldots \ldots \ldots \ldots \ldots, 1,5,9$

Dissipation structures . . . . . . . . . . . . . 13, 15, 19

Dome dunes $\ldots \ldots \ldots \ldots \ldots \ldots \ldots \ldots \ldots \ldots$
topset deposits $\ldots \ldots \ldots \ldots, \ldots, \ldots, \ldots, \ldots$

topset deposits $\ldots \ldots \ldots \ldots \ldots \ldots \ldots \ldots, \quad 9$

Drift potential $\ldots \ldots \ldots \ldots \ldots \ldots \ldots \ldots \ldots, 7$

Dunes, barchan ................ 3, 5, 6, 7, 33, 35 dip . slipface deposits

barchanoid-ridge $\ldots \ldots \ldots \ldots \ldots \ldots, 33,35$ slipface deposits $\ldots \ldots \ldots \ldots \ldots \ldots . \quad 9$

slipface deposits $\ldots \ldots \ldots \ldots \ldots \ldots \ldots \ldots \ldots \ldots \ldots \ldots \ldots \ldots \ldots \ldots \ldots \ldots \ldots \ldots \ldots$
$3,5,7$

cross-bed sets

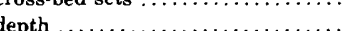

topset deposits wind erosion

dome

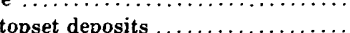

en echelon barchan $\ldots \ldots \ldots \ldots \ldots \ldots, 3,6$,

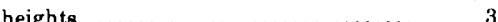

height

linear

longitudinal $\ldots \ldots \ldots \ldots \ldots \ldots \ldots \ldots$

parabolic ...

cross-bed sets . . . . . . . . . . .

topset deposits

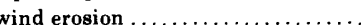

versing $\ldots \ldots \ldots \ldots$

reversing $\ldots \ldots \ldots \ldots \ldots \ldots \ldots \ldots \ldots \ldots \ldots$
Series $I \ldots \ldots \ldots \ldots \ldots \ldots \ldots \ldots \ldots$

Series II

Series III

simple. .

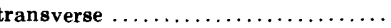

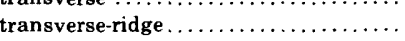
dip

lip pepenits

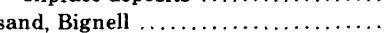

2,21

Peoria

E

elegans, Denticula $\ldots \ldots \ldots \ldots \ldots \ldots \ldots \ldots \ldots$
Elevation $\ldots \ldots \ldots \ldots \ldots \ldots \ldots \ldots \ldots$

En echelon barchan dunes $\ldots \ldots \ldots \ldots \ldots \ldots, 3,6,9$

Environ mental history ...................

Equisetum.

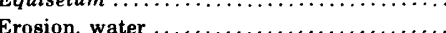

$$
\text { wind. }
$$

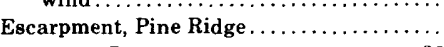

exacuous, Promenetus.............. 26, 27; pl. 1

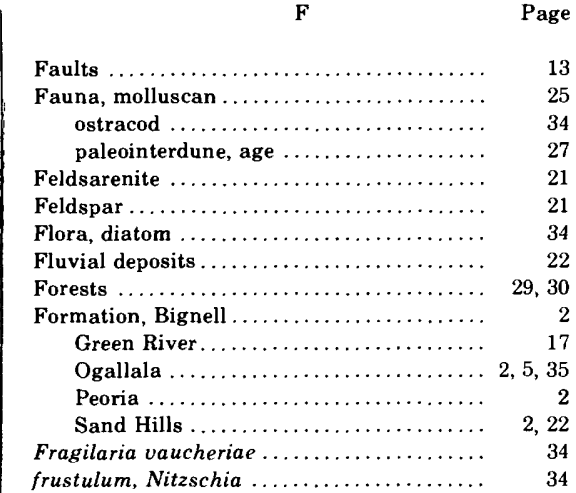

G

Gastropods, aquatic pulmonate.......... $\quad 26$

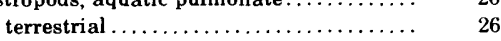
gibba, Rhopalodia .................

Glacial maximum, Wisconsin ............ 29

Gomphonema lanceolatum .............. 34 spp. .......................... 34

Gramineae........................ $\quad 34$

Great Plains, environment .............. $\quad 29$ mollusks...................... $\quad 25$

Green River Formation ................ $\quad 17$

Groundwater $\ldots \ldots \ldots \ldots \ldots \ldots \ldots \ldots \ldots, \quad 35$

Gyraulus circumstriatus ........... 26, 27; pl. 1 parvus ..................... 26, 27; pl. 1

gyrina, Physa ................... 26, 27; pl. 2

Habitat distributions $. . \ldots \ldots \ldots \ldots \ldots \ldots \ldots, \quad 26$

Hackberry Lake .................... 33, 35

Hantzschia amphioxys................. 34

Hawaiia minuscula ............... 26, 27; pl. 2

Heights, dune ..................... 3

Helisoma trivolvis .............., 26, 27; pl. 1

High Plains, Holocene mollusks .......... 25

hildrethiana, Physa ................ 26; pl. 2

History, environmental $\ldots \ldots \ldots \ldots \ldots \ldots \ldots, \quad 29$

Hooker County ................... 5, 29

organic interdune deposit $\ldots \ldots \ldots \ldots \ldots . . ., 15$

Hydrocarbons $\ldots \ldots \ldots \ldots \ldots \ldots \ldots \ldots, 17$

\section{I, J, K}

Interdune deposits $\ldots \ldots \ldots \ldots \ldots \ldots, 13,15,19,33$ localities.

thickness

Interdune ponds $\ldots \ldots \ldots \ldots \ldots$

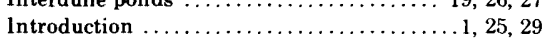

Iowa, northwestern, spruce pollen ......... 30

prairie vegetation.................. 35

italica, Melosira ....................

Jesse Lake, interdune deposits .......... $\quad 15$

Kansas, northeastern, spruce pollen ....... $\quad 30$

Krause Lake, interdune deposits .......... 15






\begin{tabular}{|c|c|}
\hline $\mathrm{L}$ & Page \\
\hline lactea, Candona ... & 34 \\
\hline Lakes, alkaline .... & 2 \\
\hline freshwater.. & 2 \\
\hline$\ldots \ldots \ldots \ldots \ldots \ldots 7,9$ & 15,21 \\
\hline ripple $\ldots \ldots \ldots \ldots \ldots \ldots \ldots \ldots \ldots \ldots$ & 13 \\
\hline lanceolatum, Gomphonema .............. & 34 \\
\hline Limnocythere ....................... & 34 \\
\hline Linear dunes $\ldots \ldots \ldots \ldots \ldots \ldots \ldots \ldots$ & 3,6 \\
\hline Location $\ldots \ldots \ldots \ldots \ldots \ldots \ldots \ldots \ldots \ldots$ & 1 \\
\hline Loess $\ldots \ldots \ldots \ldots \ldots \ldots \ldots \ldots \ldots \ldots \ldots$ & $2,5,2 \mathrm{I}$ \\
\hline Bignell ...... & 2,21 \\
\hline Peoria $\ldots \ldots \ldots \ldots \ldots \ldots \ldots \ldots \ldots$ & 2,21 \\
\hline Logan County $\ldots \ldots \ldots \ldots \ldots \ldots \ldots \ldots \ldots$ & 21,22 \\
\hline Longitudinal dunes $\ldots \ldots \ldots \ldots \ldots \ldots \ldots$ & 4 \\
\hline lybica, Amphora ovalis $\ldots \ldots \ldots \ldots \ldots \ldots$ & 34 \\
\hline Lymnaeidae $\ldots \ldots \ldots \ldots \ldots \ldots \ldots \ldots \ldots$ & 26 \\
\hline
\end{tabular}

\section{M}

Macrofossils ........................ 35 Macrophytes, aquatic $\ldots \ldots \ldots \ldots \ldots \ldots \ldots . \quad 30$ Manitoba, boreal spruce forests ........... 30 Melosira italica ...................... 34

Merritt Reservoir . . . . . . . . . . . . . . 13

Middle Loup River .................. 1, 5, 9

Minnesota, southern, prairie vegetation .... 35 spruce pollen

minuscula, Hawaiia............... 26, 27; pl. 2

Missouri, west-central, spruce pollen........

Mollusks ............................

habitat distributions ................

Holocene ...................... 27

Great Plains .

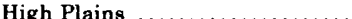

Sand Draw ...

nonmarine.......

paleointerdune

taphonomy

taxonomy....

Montmorillonite.

Montmorillonite-illite $\ldots \ldots \ldots \ldots \ldots \ldots \ldots \ldots, \quad 15$

$\mathrm{N}, \mathrm{O}$

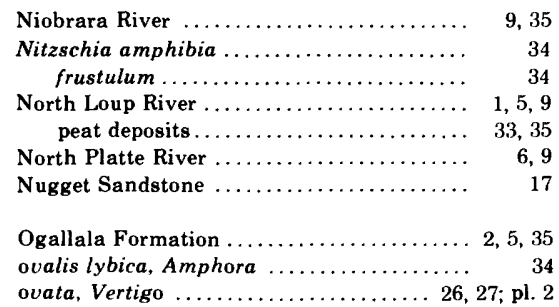

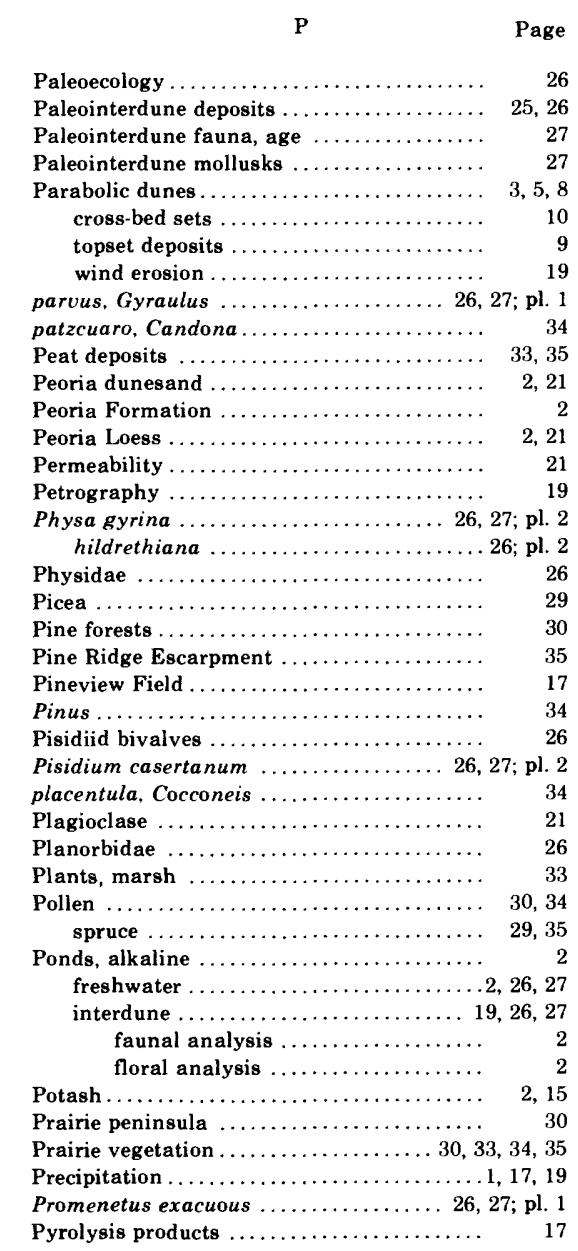

Q, R

Quartz.......................... 21

reflexa, Stagnicola ................. 26, 27; pl. 2 Rhopalodia gibba ..................... 34

Ripples $\ldots \ldots \ldots \ldots \ldots \ldots \ldots \ldots \ldots \ldots \ldots, 13,15,21$

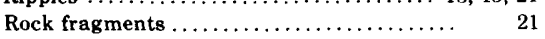

Rosebud $\ldots \ldots \ldots \ldots \ldots \ldots \ldots \ldots \ldots \ldots \ldots \ldots \ldots, 30,35$

\section{$\mathbf{S}$}

Sand Draw, Holocene mollusks........... $\quad 25$ local fauna, age 27
Page

Sand Hills Formation $\ldots \ldots \ldots \ldots \ldots \ldots \ldots, 2,22$

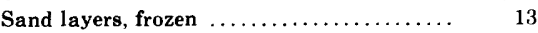

Sand roses....

Sand transport directions $\ldots \ldots \ldots \ldots \ldots$

Sandstone, nugget $\ldots \ldots \ldots \ldots \ldots \ldots \ldots, \quad 17$

Sedimentary structures $\ldots \ldots \ldots \ldots \ldots \ldots \ldots, \quad 8$

Series I dunes.

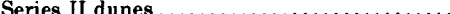

Series

Sheridan County.

Silt

3

Slipface deposits ................. 8, 9, 19, 21

Slumping $\ldots \ldots \ldots \ldots \ldots \ldots \ldots \ldots \ldots \ldots, \quad 19$

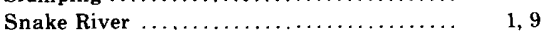

South Dakota, southern, spruce pollen..... 30

Sphaerium sp. ...................... 26, 27

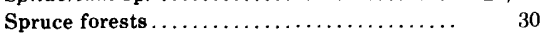

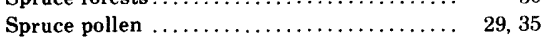

Stagnicola reflexa ................ 26, 27; pl. 2

Succinea sp. .................... 26, 27; pl. 2

Swan Lake ........................ 33,35

Taphonomy, mollusks................. $\quad 26$

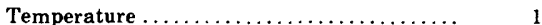

Texas, Llano Estacado, spruce pollen .......

Thermophilous forests $\ldots \ldots \ldots \ldots \ldots \ldots \ldots . . . \ldots$

Topset deposits $\ldots \ldots \ldots \ldots \ldots \ldots \ldots \ldots \ldots, 8,9,19,21$

Transport, sand ....................... 7

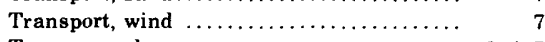

Transverse dunes $\ldots \ldots \ldots \ldots \ldots \ldots \ldots \ldots \ldots \ldots \ldots \ldots \ldots \ldots \ldots \ldots \ldots \ldots \ldots \ldots \ldots \ldots, 4,7$

Transverse-ridge dunes $\ldots \ldots \ldots \ldots \ldots \ldots \ldots, 3,5,6$

$\operatorname{dip} \ldots \ldots \ldots \ldots \ldots \ldots \ldots \ldots \ldots \ldots, \quad 8$

slipface deposits $\ldots \ldots \ldots \ldots \ldots \ldots \ldots \ldots, \quad 9$

trivolvis, Helisoma ................. 26, 27; pl. 1

Trough cross-bed sets $\ldots \ldots \ldots \ldots \ldots \ldots \ldots . \quad 10$

$\mathrm{V}$

vaucheriae, Fragilaria ................. $\quad 34$

Vegetation $\ldots \ldots \ldots \ldots \ldots \ldots \ldots \ldots \ldots \ldots \ldots \ldots \ldots \ldots \ldots \ldots, 8,30$

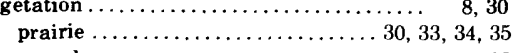
records ........................ 29

Vertigo ovata ................... 26, 27; pl. 2 vidua, Cypridopsis ...................... $\quad 34$ Virgo Park, spruce pollen $\ldots \ldots \ldots \ldots \ldots \ldots . .30$

\section{W, Y}

Water erosion $\ldots \ldots \ldots \ldots \ldots \ldots \ldots \ldots \ldots \ldots \ldots$

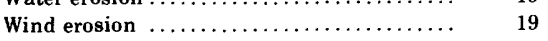

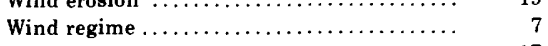

Wyoming $\ldots \ldots \ldots \ldots \ldots \ldots \ldots \ldots \ldots, \quad 17$

Yardangs ........................... $\quad 19$ 


\section{PLATES 1 AND 2}




\section{PLATE 1}

Figures 1-3. Helisoma trivolvis (Say).

Right side, left side, apertural view, USNM+1210232, USGS Loc. D1117NM, X 4. 4-6. Gyraulus circumstriatus (Tryon).

Right side, apertural view (note apertural callus), left side, USNM 210233, USGS Loc. D1116NM, X 10. 7-9. Promenetus exacuous (Say).

Right side, apertural view, left side, USNM 210234, USGS Loc. D1116NM, X 10.

10-12. Gyraulus parvus (Say).

Right side, apertural view, left side, USNM 210235, USGS Loc. D1116NM, X 10.

${ }^{1}$ USNM, United States National Museum, in Washington, D.C., where specimens are deposited. 

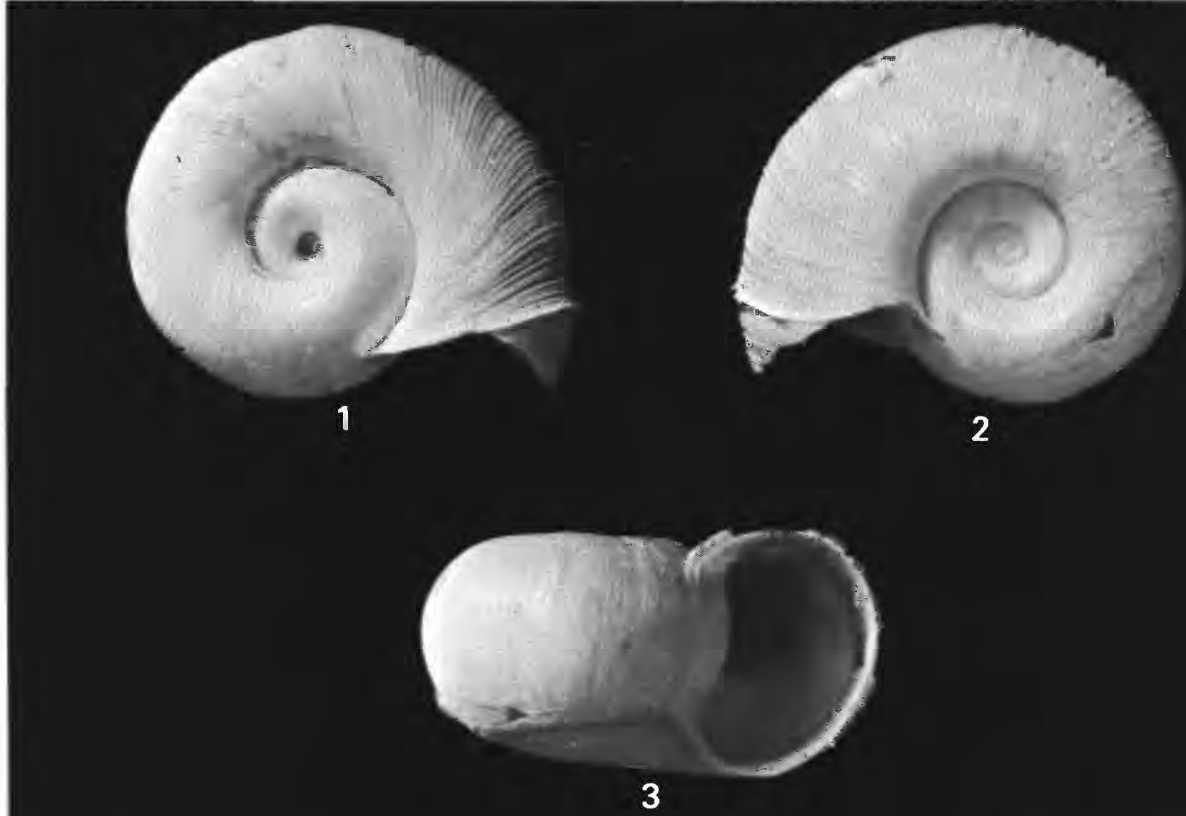

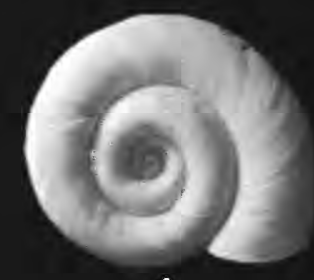

4
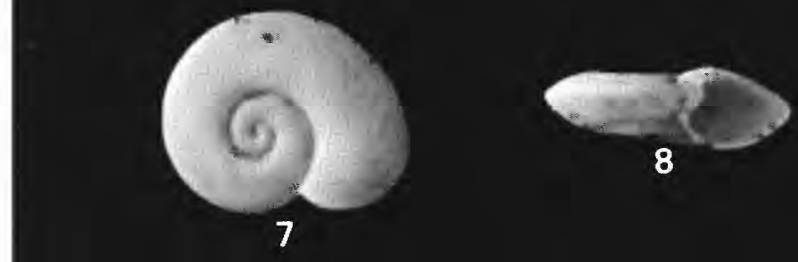

8

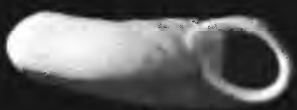

5
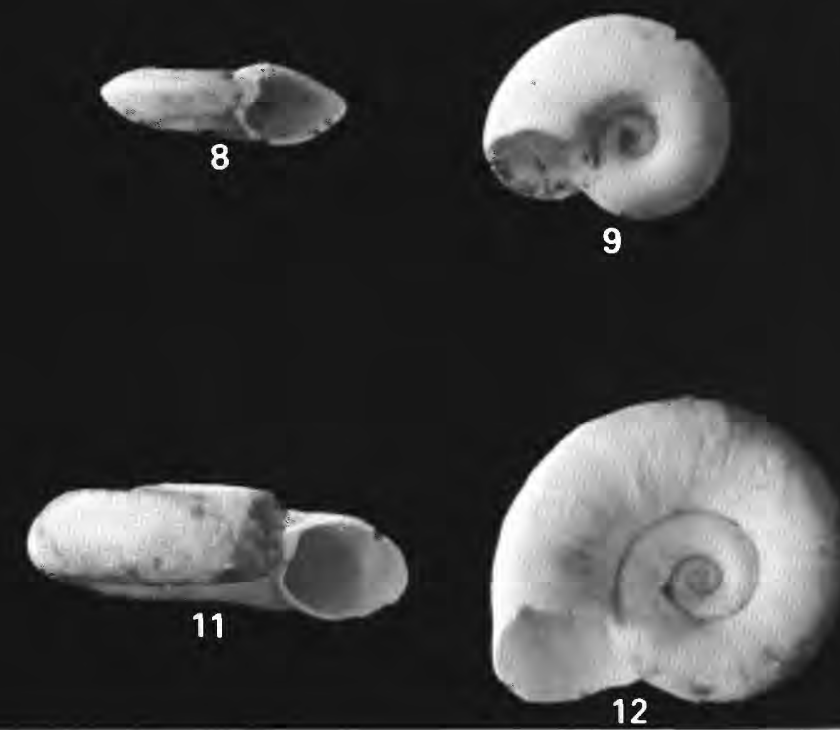

10
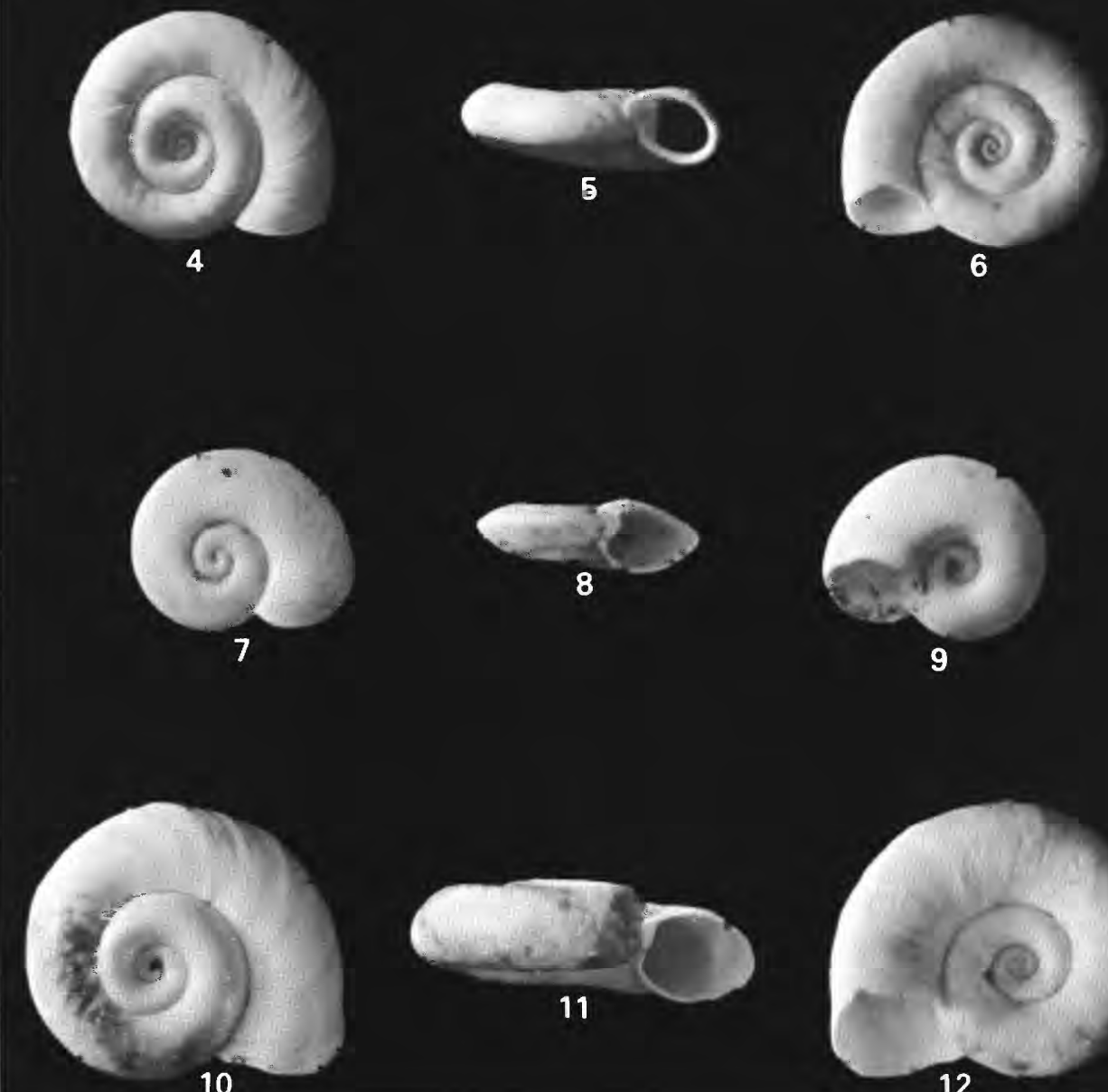

HELISOMA, GYRAULUS, AND PROMENETUS 


\section{PLATE 2}

Figures 1-2. Pisidium casertanum (Poli).

Internal and external views of right valve, USNM ${ }^{1} 210236$, USGS Loc. D1119NM X 20.

3. Vertigo ovata Say.

Apertural view. Specimen inadvertently destroyed. USGS Loc. D1116NM, X 20.

4-7. Armiger crista (Linnaeus).

4-6, Right side. Apertural view, left side, USNM 210237, USGS Loc. D1116NM, X 10; 7, Right side (note peripheral costae), USNM 210238, USGS Loc. D1116NM, X 10.

8-9. Physa gyrina Say, form hildrethiana Lea.

Abapertural and apertural views, USNM 210239, USGS Loc. D1117NM, X6.

10-12. Hawaiia minuscula (Binney).

Apical, umbilical, and apertural views, USNM 210240, USGS Loc. D1116NM; X 10.

13-14. Succinea? sp. indet.

Abapertural and apertural views, USNM 210241, USGS Loc. D1117NM, X 6.

15-16. Stagnicola reflexa (Say).

Abapertural and apertural views, USNM 210242, USGS Loc. D1117NM, X 2.

${ }^{1}$ USNM, United States National Museum, in Washington, D.C., where specimens are deposited. 

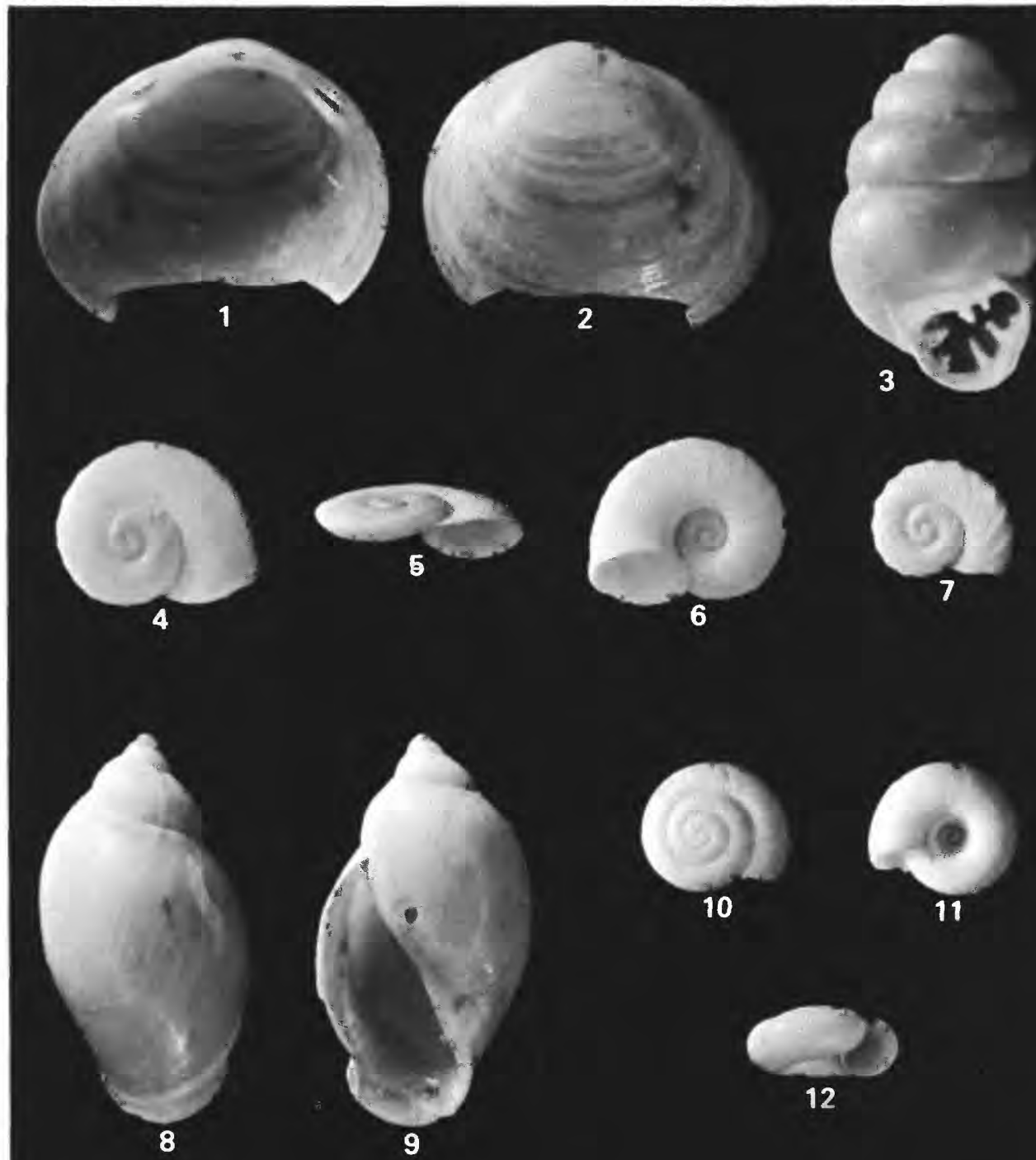

9
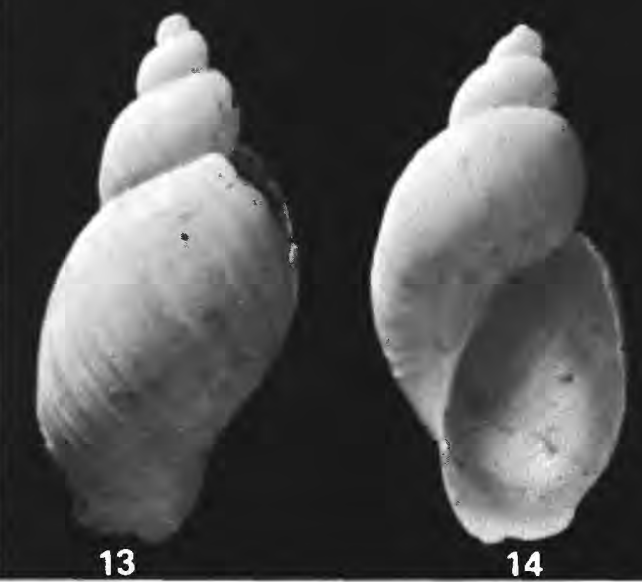

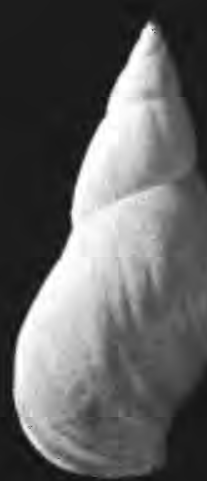

15

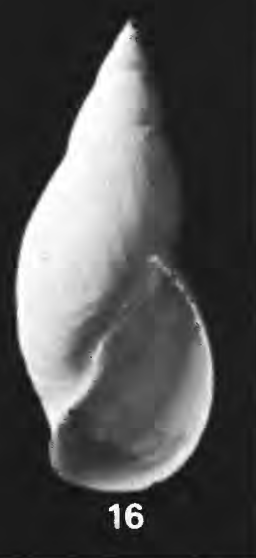

PISIDIUM, VERTIGO, ARMIGER, PHYSA, HAWAIIA, SUCCINEA?, AND STAGNICOLA 


